\title{
High diversity of Ganoderma and Amauroderma (Ganodermataceae, Polyporales) in Hainan Island, China
}

\section{Hapuarachchi $\mathrm{KK}^{1,2,3}$, Karunarathna $\mathrm{SC}^{4}$, Raspé $\mathrm{O}^{5,6}$, De Silva $\mathrm{KHWL}^{7,8}$, Thawthong $\mathrm{A}^{2,3}$, Wu XL ${ }^{9}$, Kakumyan $\mathrm{P}^{3}$, Hyde $\mathrm{KD}^{2,3,4}$ and Wen $\mathrm{TC}^{1^{*}}$}

\author{
${ }^{1}$ The Engineering Research Center of Southwest Bio-Pharmaceutical Resource Ministry of Education, Guizhou \\ University, Guiyang 550025, Guizhou Province, China \\ ${ }^{2}$ Center of Excellence in Fungal Research, Mae Fah Luang University, Chiang Rai 57100, Thailand \\ ${ }^{3}$ School of Science, Mae Fah Luang University, Chiang Rai 57100, Thailand \\ ${ }^{4}$ Key Laboratory for Plant Diversity and Biogeography of East Asia, Kunming Institute of Botany, Chinese Academy of \\ Sciences, 132 Lanhei Road, Kunming 650201, China \\ ${ }^{5}$ Botanic Garden Meise, Nieuwelaan 38, 1860 Meise, Belgium \\ ${ }^{6}$ Fédération Wallonie-Bruxelles, Service général de l'Enseignement universitaire et de la Recherche scientifique, Rue \\ A. Lavallée 1, 1080 Bruxelles, Belgium \\ ${ }^{7}$ Research Group of Aquatic Plant Ecology, Donghu Experimental Station of Lake Ecosystem, Institute of \\ Hydrobiology, Chinese Academy of Sciences, Wuhan, 430072, China \\ ${ }^{8}$ University of Chinese Academy of Sciences, Beijing 100049, China \\ ${ }^{9}$ Guizhou Academy of Sciences, Guiyang, 550009, Guizhou Province, China
}

Hapuarachchi KK, Karunarathna SC, Raspé O, De Silva KHWL, Thawthong A, Wu XL, Kakumyan P, Hyde KD, Wen TC 2018 - High diversity of Ganoderma and Amauroderma (Ganodermataceae, Polyporales) in Hainan Island, China. Mycosphere 9(5), 931-982, Doi 10.5943/mycosphere/9/5/1

\begin{abstract}
Species of Amauroderma and Ganoderma (Ganodermataceae) have been widely used as traditional medicines in Asia over many centuries. The genera are widely researched, owing to their beneficial medicinal properties and chemical constituents with potential nutritional and therapeutic uses. There are, however, taxonomic confusions surrounding the species in these genera, whose circumscription is often unclear. We surveyed species of Amauroderma and Ganoderma in Hainan Island in Southern China. In this paper, we provide data on 15 species found in the Wuzhishan and Jiangfengling mountains on the island. One species named Ganoderma ellipsoideum Hapuar., T.C. Wen \& K.D. Hyde, sp. nov. is new to science and introduced with evidence from morphology and molecular analysis. The other species collected are described with photographs and compared with similar taxa. We provide a phylogeny for the two genera based on ITS sequence data and the taxonomic status of the species is briefly discussed.
\end{abstract}

Key words - 1 new species - ITS - Lingzhi - Morphology - Phylogeny

\section{Introduction}

Ganodermataceae (Basidiomycota) is a large, cosmopolitan family of polypores with five accepted genera: Amauroderma Murril, Ganoderma P. Karst, Haddowia Steyaert, Humphreya Steyaert and Polyporopsis Audet (Richter et al. 2015) including 592 epithets, of which about three fourths are classified under the genus Ganoderma (www.indexfungorum.org, accessed 21 August 
2018). Recently, Foraminispora Robledo, Costa-Rezende \& Drechsler-Santos was introduced to accommodate Porothelium rugosum (= Amauroderma sprucei) and Furtadoa Costa-Rezende, Robledo \& Drechsler-Santos was introduced to accommodate, Amauroderma brasiliensis (Singer) Ryvarden and A. corneri Gulaid \& Ryvarden, as well as a new species Furtadoa biseptata CostaRezende, Drechsler-Santos \& Reck (Costa-Rezende et al. 2017). Furthermore, some researchers support the claim of legitimacy of Magoderna Steyaert to accommodate Ganoderma subresinosum (Murrill) C.J. Humphrey with strong morphological and molecular evidence (Gomes-Silva et al. 2015, Costa-Rezende et al. 2016, 2017). Ganodermataceae is distinct from other families of polypores in having peculiar double-walled basidiospores (with interwall pillars for Ganoderma) and the inner wall of the Ganodermataceae spores is quite often coloured, and usually the surface is ornamented (Donk 1964, Adaskaveg \& Gilbertson 1988)). Furthermore, the basidiospores also bear an apical, often shrunk umbo, and the apex appears as truncate (Smith \& Sivasithamparam 2000). Seo \& Kirk (2000) described basidia of members of Ganodermataceae as relatively large and ranging from typically clavate to pyriform. The hyphal system is usually trimitic, but occasionally dimitic or monomitic, and is comprised of hyaline, thin-walled, branched, septate or aseptate and clamped generative hyphae, as well as pigmented, thick-walled, arboriform or aciculiform and branched skeletal hyphae, and usually colourless, terminal branched binding hyphae, if present.

Ganoderma and Amauroderma are the two most important genera in Ganodermataceae. Ganoderma was established by Karsten (1881) with G. lucidum (Curtis) P. Karst as the type species. This fungus is distributed all over the world in green ecosystems both in temperate and tropical regions and grow as facultative parasites that can live as saprobes on rotting stumps and roots (Turner 1981). Ganoderma species are not classified as edible mushrooms, as the basidiomes are always corky and tough and do not have the fleshy texture characteristic of true edible mushrooms (Hapuarachchi et al. 2015). Basidiomes grow on living, or more commonly, dead trunks or branches of trees. One of two types of basidiomes is produced, depending on the species: laccate basidiomes with a shiny upper surface, or non-laccate basidiomes with a dull upper surface (Smith \& Sivasithamparam 2003, Pilotti et al. 2004). The members of family Ganodermataceae have been widely used as traditional medicines over many centuries in Asia (Zhou et al. 2015). Species in Ganodermataceae are widely researched, because they contain many chemical constituents with potential nutritional and therapeutic values and, therefore, have highly prized medicinal value (De Silva et al. 2012a, b, 2013, Hapuarachchi et al. 2016a, b, 2017). Ganoderma species are economically important not only because of their medicinal properties, but also because of their phytopathogenicity (Dai et al. 2007, 2009). Ganoderma species cause white rot of hard woods by decomposing lignin, cellulose and related polysaccharides (Hepting 1971, Adaskaveg et al. 1991). The root and stem rots caused by Ganoderma species, result in forestry yield loss worldwide, in important trees such as Elaeis guineensis (oil palm; Glen et al. 2009) and Hevea brasiliensis (rubber; Monkai et al. 2016). Yu \& Shen (2003) reported that Ganoderma (Lingzhi) was successfully cultivated for the first time in 1969 in China. Ganoderma products, from different parts of the basidiomes, mycelia or spores, are sold in the form of powder, coffee, tea or other drinks, dietary supplements, syrups, tooth pastes, soaps and lotions (Chang \& Buswell 1999, Lai et al. 2004, Singh et al. 2013).

After the genus Ganoderma was established, Patouillard (1887) transferred other species to Ganoderma, and Karsten (1889) introduced the genus Elfvingia for non-laccate Ganoderma species. Furthermore, Patouillard (1889) introduced section Amauroderma for species with spherical and subspherical basidiospores with uniformly thickened walls. Ganoderma P. Karst. comprises sect. Amauroderma, Ganoderma, subgenera, Ganoderma and Trachyderma to date (www.indexfungorum.org, accessed 21 August 2018). The genus Ganoderma was first divided into two sub-genera, Ganoderma and Elfvingia by Karsten (1889). Various authors have used different taxonomic characters for the identification of the species (Murrill 1902, 1903, Atkinson 1908, Coleman 1927, Corner 1947). The pileipellis has been differently characterized by different authors: Furtado (1965) referred to a derm of the palisadoderm type in Elfvingia and layer of cells in a hymeniderm in Ganoderma, while Steyaert (1980) referred to a trichoderm in Elfvingia and 
"hymenioderm" in subg. Ganoderma. Clemençon (2004) used "crustohymeniderm" for subg. Ganoderma. However, Steyaert (1972, 1980) worked extensively on the genus and he introduced many new species, transferred many names to the genus and removed several synonyms. Ryvarden (1995), Gottlieb \& Wright (1999a, b) studied the macro and micromorphology of this genus further. Later, isoenzyme analysis techniques have been used to separate the species of Ganoderma (Park et al. 1994, Gottlieb et al. 1995, 1998, Gottlieb \& Wright 1999a, Smith \& Sivasithamparam 2000). Furthermore, ribosomal DNA sequencing tools have been used to analyse the phylogenetic relationship in Ganoderma lucidum complex (Moncalvo et al. 1995a, b, c). Hseu et al. (1996) used RAPD-Polymerase chain reaction (PCR) and internal transcribed spacer (ITS) sequences to differentiate the isolates of $G$. lucidum complex. Although phylogenetic analyses support the monophyly of Ganoderma and its classification into two subgenera, there are many problems in the resolution below the sub generic level (Moncalvo 2000, Hong \& Jung 2004).

Despite their huge economical importance, the taxonomy of Ganoderma remains unclear, because it has been plagued by confusions and misconceptions. Ganoderma is called "Ling Zhi", Chi-zhi" or "Rui-zhi" in China; "Reishi", "Munnertake" or "Sachitake" in Japan and "Youngzhi" in Korea (Wagner et al. 2003). Traditional Chinese books classified Ganoderma into six species with reference to the colour of the basidiomes: Sekishi (red), Shishi (violaceous), Kokushi (black), Oushi (yellow), Hakushi (white) and Seishi (blue), and were assigned to different species based on different triterpenoid patterns (Szedlay 2002). Ganoderma was first reported from China by Teng (1934), with four species including G. lucidum and one variety. Later, many researchers extensively studied Chinese Ganodermataceae and introduced more than 100 species in four genera: Ganoderma, Amauroderma, Haddowia and Humphreya (Zhao \& Zhang 2000, Wu \& Dai 2005, Cao et al. 2012). Ganoderma lucidum was accepted as the scientific binomial of "Lingzhi" in many reports on Chinese edible and medicinal mushrooms, but it was recently described as $G$. lingzhi based on strong molecular and morphological evidence (Cao et al. 2012, Dai et al. 2017). Mycochemical and other studies reported different species numbers in the genus Ganoderma (Peng et al. 2014, Yan et al. 2013). However, the majority of Ganoderma species reported from China have not been subjected to systematic studies (Baby et al. 2015). There are 445 epithets listed in Index Fungorum (accessed 21 August 2018) for Ganoderma, while Kirk et al. (2008) estimated there were 80 species worldwide although part of them are synonyms.

Ganoderma species identification has been difficult and recently debated by many researchers (Moncalvo et al. 1995a, Wang et al. 2009, Cao et al. 2012, Yao et al. 2013, Richter et al. 2015, Zhou et al. 2015). A number of Ganoderma collections and species have been misnamed because of the presence of heterogenic forms, taxonomic obstacles and inconsistencies in the way the genus has been subdivided (Mueller et al. 2007). Ganoderma species have been reported to be genetically heterogeneous because of geographical differentiation, and high genetic diversity is maintained by out-crossing between generations (Miller et al. 1999, Pilotti et al. 2003). This high genetic diversity is accompanied by substantial morphological variation, even within species (Hong et al. 2001). Hence, naming a species within this genus often is problematic and traditional taxonomic methods based only on morphology are insufficient for establishing a stable classification system for Ganoderma (Hseu et al. 1996, Hong et al. 2002, Thawthong et al. 2017), which has resulted in an uncertain nomenclature. This confusing situation is mainly the result of various criteria used in identification by different authors. Some authors strictly focus on hostspecificity, geographical distribution and macro morphology of basidiomes, while other authors only focus on spore characteristics as the primary taxonomic characteristics (Sun et al. 2006, Ekandjo \& Chimwamurombe 2012). Recently, some researchers have suggested using a combination of morphological, chemotaxonomic and molecular methods to develop a more stable taxonomy for this genus (Richter et al. 2015, Welti et al. 2015).

Amauroderma Murrill (1905) was introduced and typified by Amauroderma regulicolor (Berk. ex Cooke) Murrill and this is a widespread tropical genus with 135 epithets listed in Index Fungorum (accessed 21 August 2018). Species of Amauroderma usually occur on roots of living or dead trees or, more rarely, are wood inhabiting (Furtado 1981, Ryvarden 2004) and cause white rot. 
Members of this genus vary from stipitate to sessile with non-truncate, globose to subglobose, verrucose to asperulate (smooth in only one species) basidiospores (Ryvarden 2004). Taxonomic studies of Amauroderma in China have been carried out over many years by various researchers (Teng 1936, Zhao et al. 1979, Zhao \& Zhang 1987, Li \& Yuan 2015, Song et al. 2016). Twenty species have been recorded in China (Zhao \& Zhang 2000), but among these, only six have been confirmed as Amauroderma based on both morphological characters and phylogenetic analyses: $A$. austrosinense J.D. Zhao \& L.W. Hsu, A. concentricum Song, Xiao L. He \& B.K. Cui, A. perplexum Corner, A. rugosum (Blume \& T. Nees) Torrend, A. subresinosum (Murrill) Corner and A. yunnanense J.D. Zhao \& X.Q. Zhang (Li \& Yuan 2015). The other Amauroderma species recorded from China, have not been fully studied yet.

Hainan Province is an island in southern China located between $18^{\circ} 10^{\prime}-20^{\circ} 10^{\prime} \mathrm{N}$ and $108^{\circ}$ $37^{\prime}-111^{\circ} 05^{\prime} \mathrm{E}$ (Fig. 1). It has both lowland areas in the northeast and mountainous terrain in the central and southwestern regions. The average annual temperature and precipitations are $19.7{ }^{\circ} \mathrm{C}$ and $2650 \mathrm{~mm}$, respectively. This island has subtropical to tropical vegetations (Dai et al. 2011). Several studies have been carried out over the past three decades to investigate the Ganoderma diversity of Hainan Island (Wu et al. 1999, Li et al. 2010, Dai et al. 2011, Wang et al. 2012).

The objective of the present study is to document the members of Ganoderma and Amauroderma found in Wuzhishan and Jiangfengling Mountains on Hainan Island with descriptions, colour photographs, illustrations and a phylogeny. All the species of Amauroderma and Ganoderma are compared with similar taxa. A checklist of species of Amauroderma and Ganoderma reported from Hainan Island is also given in Table 1.

\section{Check-list of the species of Amauroderma and Ganoderma known for Hainan Island}

The authors of the scientific names in the following list are given according to Index Fungorum, 2018 (http://www.indexfungorum.org/names/Names.asp) (Table 1).

\section{Materials \& Methods}

Samples of Ganoderma were collected in August 2014 from Wuzhishan and Jiangfengling Mountains, Hainan Province, China and dealt with as in Cao et al. (2012). The materials were deposited at Guizhou University (GACP) and Mae Fah Luang University (MFLU) herbaria.

\section{Morphological characteristics examination}

Macro-morphological characters were described based on fresh material, and on the photographs provided here. Colour codes (e.g. 3A3) are from Kornerup \& Wanscher (1978). Specimens were dried and placed separately in plastic bags. For micro-morphological observations, basidiomes were examined under a stereo dissecting microscope (Motic SMZ 168 series) and sections were cut with a razor blade, mounted in $5 \% \mathrm{KOH}$, and then observed, measured and illustrated under a compound microscope (Nikon ECLIPSE 80i) equipped with a camera (Canon 600D). Measurements were made using Tarosoft (R) Image Frame Work v. 0.9.7. At least 20 basidiospores were measured from each mature specimen except for very scanty materials. The basidiospore size was measured both with and without the myxosporium, but only spore sizes with myxosporium were used for comparisons. Basidiospore dimensions are given as $(a-) b-c-d(-e)$, where a represents the minimum, b (mean average-standard deviation), c the average, $d$ (mean average+standard deviation) and e the maximum. $Q$, the length/width ratio $(\mathrm{L} / \mathrm{W})$ of a spore in side view and $Q_{m}$ is the average, smallest and largest $Q$ values given as $Q$. Pellis sections were taken from the mature pileus portion and mounted in Melzer's reagent for observation. The Facesoffungi number is provided as explained in Jayasiri et al. (2015).

\section{DNA extraction, PCR, and sequencing}

Samples taken from dried basidiome were used to extract genomic DNA. Genomic DNA was extracted using an EZgene ${ }^{\mathrm{TM}}$ Fungal gDNA Kit (Biomiga, CA, USA) according to the manufacturer instructions. DNA concentrations were estimated visually on agarose gel by 
comparing band intensity with $1 \mathrm{~Kb}$ DNA ladder (Invitrogen Biotech). The nuclear ribosomal internal transcribed spacers region (ITS) was amplified using primers ITS5 and ITS4 (White et al. 1990). Reaction mixtures $(20 \mu \mathrm{l})$ contained $1 \mu \mathrm{l}$ template DNA (ca. $10 \mathrm{ng}$ ), $10 \mu \mathrm{l}$ distilled water, and $1 \mu \mathrm{l}(10 \mu \mathrm{M})$ of each primer and $7 \mu \mathrm{l} 2 \times$ BenchTop $^{\mathrm{TM}}$ Taq Master Mix (Biomigas). Amplification conditions were $2 \mathrm{~min}$ at $94{ }^{\circ} \mathrm{C}$ followed by 35 cycles of $95 \mathrm{C}$ for $30 \mathrm{~s}, 59{ }^{\circ} \mathrm{C}$ for 30 $\mathrm{s}$ and $72{ }^{\circ} \mathrm{C}$ for $1 \mathrm{~min}$, followed by a final extension at $72{ }^{\circ} \mathrm{C}$ for $10 \mathrm{~min}$. Amplified PCR products were verified by $1 \%$ agarose gel electrophoresis stained with ethidium bromide in $1 \mathrm{x}$ TBE. The PCR products were sequenced by Invitrogen Biotechnology (Beijing).

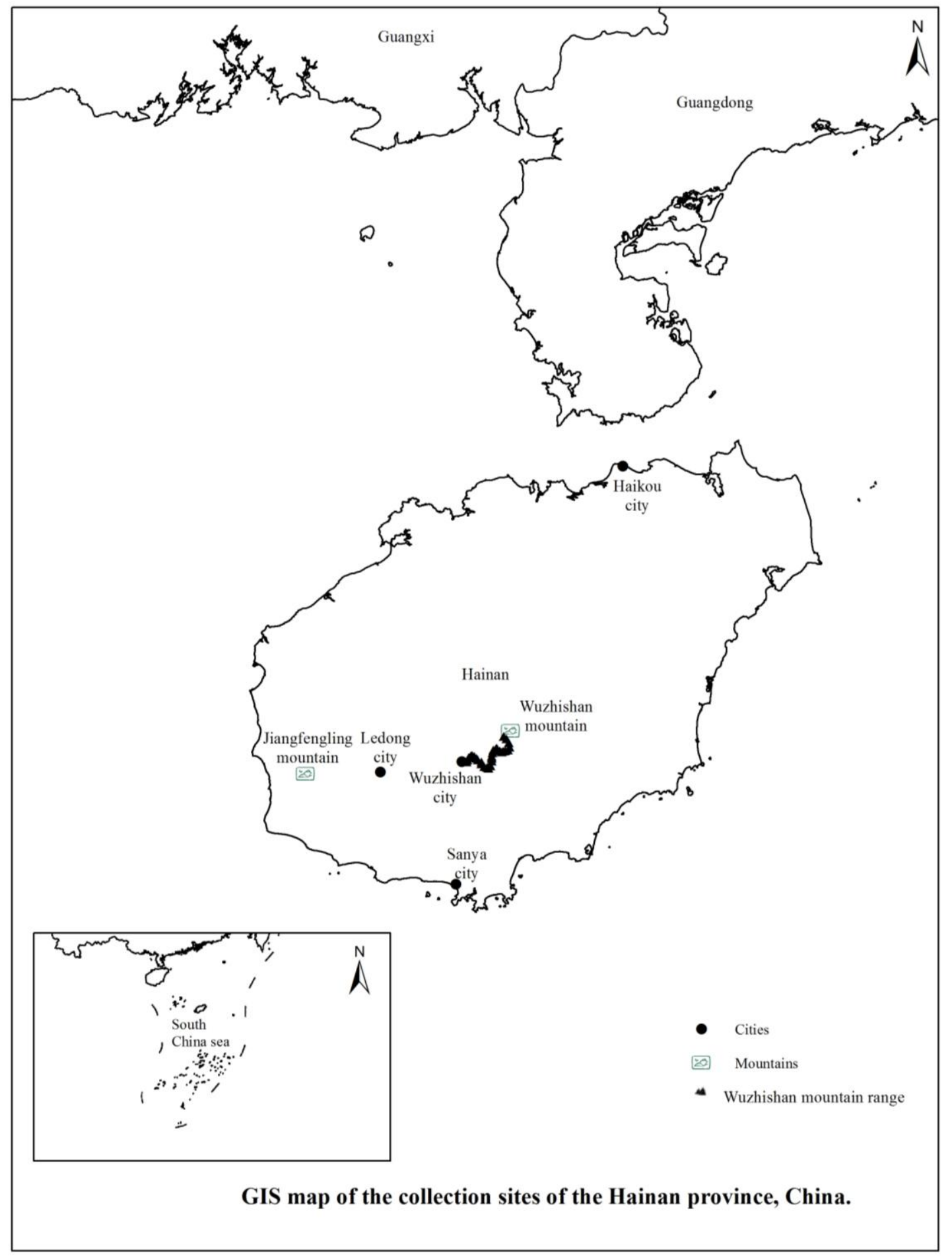

Figure 1 - Location of Wuzshishan and Jiangfengling Mountains and other areas of collection in Hainan province, China (This map was prepared using the freely available online map data (Global Administrative Areas http://www.gadm.org/download, accessed March 6, 2017). 
Table 1 List of Amauroderma and Ganoderma species known for Hainan Island

\begin{tabular}{|c|c|c|c|}
\hline Taxa & $\begin{array}{l}\text { Status } \\
\text { (verified/unverified) }\end{array}$ & $\begin{array}{l}\text { Current } \\
\text { name }\end{array}$ & Reference \\
\hline $\begin{array}{l}\text { Amauroderma rugosum } \\
\text { (Blume \& T. Nees) Torrend } \\
\text { (1920) }\end{array}$ & verified & & $\begin{array}{l}\text { Wu et al. } 1999, \\
\text { Li et al. } 2010 \\
\text { Li \& Yuan } 2015 \text {, } \\
\text { This study }\end{array}$ \\
\hline $\begin{array}{l}\text { A. austrosinense J.D. Zhao \& } \\
\text { L.W. Hsu (1984) }\end{array}$ & verified & & $\begin{array}{l}\text { Wu et al. } 1999, \\
\text { Li \& Yuan } 2015, \\
\text { This study }\end{array}$ \\
\hline $\begin{array}{l}\text { Ganoderma ahmdii Steyaert } \\
\text { (1972) }\end{array}$ & unverified & & Wu et al. 1999 \\
\hline $\begin{array}{l}\text { G. amboinense (Lam.) Pat. } \\
\text { (1887) }\end{array}$ & unverified & & Wu et al. 1999 \\
\hline $\begin{array}{l}\text { G. annulare (Jungh.) Gilb. } \\
\text { (1962) }\end{array}$ & verified & $\begin{array}{l}\text { G. australe } \\
\text { (Fr.) Pat. } \\
\text { (1889) }\end{array}$ & $\begin{array}{l}\text { Wu et al. } 1999 \text {, } \\
\text { Dai et al. 2011, } \\
\text { This study }\end{array}$ \\
\hline $\begin{array}{l}\text { G. applanatum (Pers.) Pat. } \\
(1887)\end{array}$ & verified & & $\begin{array}{l}\text { Wu et al. } 1999 \text {, } \\
\text { This study }\end{array}$ \\
\hline $\begin{array}{l}\text { G. atrum J.D. Zhao, L.W. Hsu } \\
\text { \& X.Q. Zhang (1979) }\end{array}$ & unverified & $\begin{array}{l}\text { G. flexipes } \\
\text { Pat. (1907) }\end{array}$ & $\begin{array}{l}\text { Wu et al. } 1999 \text {, } \\
\text { Wang \& Wu } 2007 \\
\text { This study }\end{array}$ \\
\hline G. australe (Fr.) Pat. (1889) & verified & & $\begin{array}{l}\text { Wu et al. } 1999, \\
\text { Li et al., 2010, } \\
\text { Dai et al. } 2011, \\
\text { This study }\end{array}$ \\
\hline $\begin{array}{l}\text { G. bawanglingense J.D. } \\
\text { Zhao \& X.Q. Zhang (1987) }\end{array}$ & Unverified & & Li et al. 2010 \\
\hline G. boninense Pat. (1889) & unverified & $\begin{array}{l}\text { G. } \\
\text { orbiforme } \\
\text { (Fr.) } \\
\text { Ryvarden } \\
2000\end{array}$ & $\begin{array}{l}\text { Wu et al. } 1999 \text {, } \\
\text { Dai et al. } 2011\end{array}$ \\
\hline $\begin{array}{l}\text { G. brownii (Murrill) Gilb. } \\
\text { (1962) }\end{array}$ & unverified & & Wu et al. 1999 \\
\hline $\begin{array}{l}\text { G. calidophilum J.D. Zhao, } \\
\text { L.W. Hsu \& X.Q. Zhang } \\
\text { (1979) }\end{array}$ & verified & & $\begin{array}{l}\text { Li et al. } 2010 \text {, } \\
\text { Dai et al. } 2011 \text {, } \\
\text { This study }\end{array}$ \\
\hline $\begin{array}{l}\text { G. capense (Lloyd) Teng } \\
\text { (1963) }\end{array}$ & unverified & & Wu et al. 1999 \\
\hline $\begin{array}{l}\text { G. chalceum var. chalceum } \\
\text { (Cooke) Steyaert (1967) }\end{array}$ & unverified & & Wu et al. 1999 \\
\hline $\begin{array}{l}\text { G. cochlear (Blume \& T. } \\
\text { Nees) Merr. (1917) }\end{array}$ & unverified & & Wu et al. 1999 \\
\hline $\begin{array}{l}\text { G. cupreum (Cooke) Bres. } \\
\text { (1911) }\end{array}$ & verified & $\begin{array}{l}\text { G. } \\
\text { orbiforme }\end{array}$ & $\begin{array}{l}\text { Wu et al. } 1999, \\
\text { Wang et al. 2014, } \\
\text { This study }\end{array}$ \\
\hline $\begin{array}{l}\text { G. curtisii (Berk.) Murr. } \\
\text { (1908) }\end{array}$ & unverified & & Wu et al. 1999 \\
\hline $\begin{array}{l}\text { G. dahlii (Henn.) Aoshima } \\
\text { (1971) }\end{array}$ & unverified & & Wu et al. 1999 \\
\hline $\begin{array}{l}\text { G. densizonatum J.D. Zhao } \\
\text { \& X.Q. Zhang (1986) }\end{array}$ & Verified & $\begin{array}{l}\text { G. } \\
\text { orbiforme }\end{array}$ & $\begin{array}{l}\text { Wu et al. 1999, } \\
\text { Wang et al. } 2014\end{array}$ \\
\hline
\end{tabular}


Table 1 Continued.

\begin{tabular}{|c|c|c|c|}
\hline Taxa & $\begin{array}{l}\text { Status } \\
\text { (verified/unverified) }\end{array}$ & $\begin{array}{l}\text { Current } \\
\text { name }\end{array}$ & Reference \\
\hline G. flexipes Pat. (1907) & verified & & $\begin{array}{l}\text { Wu et al. } 1999 \text {, } \\
\text { Zhou et al. 2015, } \\
\text { This study }\end{array}$ \\
\hline G. fornicatum (Fr.) Pat. (1889) & verified & G. orbiforme & $\begin{array}{l}\text { Wu et al. } 1999 \text {, } \\
\text { Wang et al. } 2014 \text {, } \\
\text { This study }\end{array}$ \\
\hline $\begin{array}{l}\text { G. gibbosum ((Blume \& T. } \\
\text { Nees) Pat. (1897) }\end{array}$ & verified & & $\begin{array}{l}\text { Dai et al. } 2011 \text {, } \\
\text { This study }\end{array}$ \\
\hline $\begin{array}{l}\text { G. hainanense J.D. Zhao, L.W. } \\
\text { Hsu \& X.Q. Zhang (1979) }\end{array}$ & unverified & G. flexipes & $\begin{array}{l}\text { Wu et al. } 1999 \text {, } \\
\text { Wang \& Wu } 2007 \text {, } \\
\text { This study }\end{array}$ \\
\hline G. hoehnelianum Bres. (1912) & & & $\begin{array}{l}\text { Wu et al. } 1999 \text {, } \\
\text { Wang \& Wu } 2010 \text {, } \\
\text { This study }\end{array}$ \\
\hline $\begin{array}{l}\text { G. jiangfenglingense X.L Wu. } \\
\text { (1996) }\end{array}$ & unverified & & Wu et al. 1999 \\
\hline G. leytense Steyaert (1972) & unverified & & Wu et al. 1999 \\
\hline $\begin{array}{l}\text { G. limushanense J.D. Zhao \& } \\
\text { X.Q. Zhang (1986) }\end{array}$ & verified & G. orbiforme & $\begin{array}{l}\text { Wu et al. } 1999 \text {, } \\
\text { Wang et al. } 2014 \text {, } \\
\text { This study }\end{array}$ \\
\hline $\begin{array}{l}\text { G. lobatum (Schwein.) G.F. } \\
\text { Atk. (1908) }\end{array}$ & unverified & & Wu et al. 1999 \\
\hline $\begin{array}{l}\text { G. Iucidum (W Curt. Fr.) } \\
\text { Karst. (1881) }\end{array}$ & unverified & & Wu et al. 1999 \\
\hline $\begin{array}{l}\text { G. luteomarginatum J.D. Zhao, } \\
\text { L.W. Hsu \& X.Q. Zhang } \\
\text { (1979) }\end{array}$ & unverified & & Wu et al. 1999 \\
\hline $\begin{array}{l}\text { G. mastoporum (Lev.) Pat. } \\
(1889)\end{array}$ & verified & G. orbiforme & $\begin{array}{l}\text { Wu et al. } 1999 \text {, } \\
\text { Wang et al. 2014, } \\
\text { This study }\end{array}$ \\
\hline $\begin{array}{l}\text { G. multipileum Ding Hou. } \\
(1950)\end{array}$ & verified & & $\begin{array}{l}\text { Dai et al. 2011, } \\
\text { Wang et al. 2005, } \\
\text { Zhou et al. 2015 }\end{array}$ \\
\hline $\begin{array}{l}\text { G. multiplicatum (Moat.)Pat. } \\
\text { (1889) }\end{array}$ & verified & & $\begin{array}{l}\text { Dai et al. } 2004 \text {, } \\
\text { This study }\end{array}$ \\
\hline $\begin{array}{l}\text { G. nigrolucidum (Lloyd) D.A. } \\
\text { Reid (1975) }\end{array}$ & unverified & & $\begin{array}{l}\text { Dai et al. } 2004 \text {, } \\
\text { Li et al. } 2010\end{array}$ \\
\hline $\begin{array}{l}\text { G. parviungulatum .D. Zhao \& } \\
\text { X.Q. Zhang (1986) }\end{array}$ & unverified & G. flexipes & $\begin{array}{l}\text { Wu et al. } 1999 \text {, } \\
\text { Cao et al. } 2012 \\
\text { This study }\end{array}$ \\
\hline $\begin{array}{l}\text { G. ramosissimum J.D. Zhao } \\
\text { (1989) }\end{array}$ & unverified & & Wu et al. 1999 \\
\hline G. resinaceum Boud (1890) & verified & & $\begin{array}{l}\text { Wu et al. } 1999 \\
\text { This study }\end{array}$ \\
\hline $\begin{array}{l}\text { G. shangsiense J.D. Zhao. } \\
\text { (1988) }\end{array}$ & Verified & $\begin{array}{l}\text { G. } \\
\text { hoehnelianu } \\
m\end{array}$ & $\begin{array}{l}\text { Li et al. } 2010 \text {, } \\
\text { Wang \& Wu } 2010 \text {, } \\
\text { This study }\end{array}$ \\
\hline $\begin{array}{l}\text { G. sinense J.D. Zhao. L.W. } \\
\text { Hsu \& X.Q. Zhang (1979) }\end{array}$ & verified & & $\begin{array}{l}\text { Dai et al. } 2004 \text {, } \\
\text { Wang et al. } 2005 \text {, } \\
\text { This study }\end{array}$ \\
\hline $\begin{array}{l}\text { G. subresinosum (Murrill) C.J. } \\
\text { Humphrey (1938) }\end{array}$ & verified & & $\begin{array}{l}\text { Wu et al. } 1999 \text {, } \\
\text { Li et al. } 2010 \\
\text { This study }\end{array}$ \\
\hline
\end{tabular}


Table 1 Continued.

\begin{tabular}{|c|c|c|c|}
\hline Taxa & $\begin{array}{l}\text { Status } \\
\text { (verified/unverified) }\end{array}$ & $\begin{array}{l}\text { Current } \\
\text { name }\end{array}$ & Reference \\
\hline $\begin{array}{l}\text { G. tornatum (Pers.) Bres. } \\
\text { (1912) }\end{array}$ & verified & G. australe & $\begin{array}{l}\text { Li et al. } 2010 \text {, } \\
\text { This study }\end{array}$ \\
\hline $\begin{array}{l}\text { G. tropicum (Jungh.) Bres. } \\
\text { (1910) }\end{array}$ & verified & & $\begin{array}{l}\text { Li et al. } 2010 \text {, } \\
\text { Zhou et al. 2015, } \\
\text { This study }\end{array}$ \\
\hline G. valesiacum Boud. (1895) & unverified & & Wu et al. 1999 \\
\hline $\begin{array}{l}\text { G. weberianum (Bres. \& Henn. } \\
\text { ex Sacc.) Steyaert (1972) }\end{array}$ & verified & & $\begin{array}{l}\text { Wu et al. } 1999 \text {, } \\
\text { Wang et al. } 2012\end{array}$ \\
\hline
\end{tabular}

\section{Sequence alignment and phylogenetic analysis}

The taxon information and GenBank accession numbers used in the molecular analyses are listed in Table 2. Quality of the newly obtained sequences from the Ganoderma specimens from Hainan Province, China was checked by observing the chromatogram with BioEdit (Hall 1999) and by examining BLAST search results according to Nilsson et al. (2012). The BLAST search was also used to retrieve sequences from the closest matching taxa in Ganodermataceae. Seventy nucleotide sequences representing 35 species of Ganodermataceae from Asia, America and Europe were retrieved from GenBank. Those sequences and 19 newly generated sequences were aligned using MAFFT v. 7.309 (Katoh \& Standley 2013) online at http://mafft.cbrc.jp/alignment/server/index.html, and the alignment was improved manually where necessary using Bioedit. Maximum Likelihood (ML) analysis was performed using RAxML-HPC2 (Stamatakis 2014) on the CIPRES Science Gateway V. 3.3 (Miller \& Blair 2009), with default settings except the number of bootstrap replicates was set to 1,000. For Bayesian (BY) analysis, GTR+I+G model of evolution was selected with MrModeltest 2.2 (Nylander 2004) as the best-fit model. BY analyses were conducted with 2 runs of six simultaneous Markov chains and trees were sampled every 100th generation. The analyses were stopped after 5,000,000 generations when the average standard deviation of split frequencies was below 0.01 . The convergence of the runs was checked using TRACER v1.6 (Rambaut et al. 2013). The first 25\% of the resulting trees were discarded as burn-in, and PP were calculated from the remaining sampled trees. In both ML and BY analyses, Coriolopsis trogii was selected as the outgroup. ML bootstrap values and Bayesian posterior probabilities greater than or equal to $70 \%$ and 0.95 , respectively, were considered as significant support. The phylogenetic tree was visualized with FigTree version 1.4.0 (Rambaut 2012) available at http://tree.bio.ed.ac.uk/software/figtree/.

Table 2 ITS sequences used in the phylogenetic analysis

\begin{tabular}{|c|c|c|c|c|}
\hline Species & $\begin{array}{l}\text { Voucher/ } \\
\text { strain }\end{array}$ & Origin & $\begin{array}{l}\text { GenBank } \\
\text { accession } \\
\text { number }\end{array}$ & Reference \\
\hline $\begin{array}{l}\text { Amauroderma } \\
\text { rugosum (Blume \& } \\
\text { T. Nees) Torrend }\end{array}$ & $\begin{array}{l}\text { GACP1408 } \\
0910\end{array}$ & Hainan, China & MH106869 & This study \\
\hline A. rugosum & $\begin{array}{l}\text { GACP1408 } \\
0952\end{array}$ & Hainan, China & MH106870 & This study \\
\hline A. rugosum & Zhou 523 & Guangxi, China & KJ531674 & Li \& Yuan 2015 \\
\hline A. rugosum & Dai9553 & Hainan, China & KJ531668 & Li \& Yuan 2015 \\
\hline A. rugosum & Cui8882 & Guangdong, China & KJ531667 & Li \& Yuan 2015 \\
\hline Ganoderma sp. & JM95/5 & Thailand & AF255122 & $\begin{array}{l}\text { Moncalvo \& } \\
\text { Buchanan } 2008\end{array}$ \\
\hline
\end{tabular}


Table 2 Continued.

\begin{tabular}{|c|c|c|c|c|}
\hline Species & $\begin{array}{l}\text { Voucher/ } \\
\text { strain }\end{array}$ & Origin & $\begin{array}{l}\text { GenBank } \\
\text { accession } \\
\text { number }\end{array}$ & Reference \\
\hline Ganoderma sp. & JM98/233 & Yunnan, China & AF255116 & $\begin{array}{l}\text { Moncalvo \& } \\
\text { Buchanan } 2008\end{array}$ \\
\hline $\begin{array}{l}\text { G. adspersum } \\
\text { (Schulzer) Donk }\end{array}$ & ITA 39 & Unknown & EF060011 & Terho et al. 2007 \\
\hline G. adspersum & PF263 & Italy & JN176908 & GenBank \\
\hline $\begin{array}{l}\text { G. applanatum } \\
\text { (Pers.) Pat. }\end{array}$ & $\begin{array}{l}\mathrm{K}(\mathrm{M}) 12082 \\
9\end{array}$ & UK & AY884179 & GenBank \\
\hline G. applanatum & Dai8924 & China & KU219987 & Song et al. 2016 \\
\hline G. australe (Fr.) Pat. & $\begin{array}{l}\text { GACP1408 } \\
1671\end{array}$ & Hainan, China & MH106871 & This study \\
\hline G. australe & $\begin{array}{l}\text { GACP1408 } \\
1134\end{array}$ & Hainan, China & MH106872 & This study \\
\hline G. australe & $\begin{array}{l}\text { GDGM258 } \\
31\end{array}$ & China & JX195200 & GenBank \\
\hline G. cupreum & $\begin{array}{l}\text { HMAS130 } \\
804\end{array}$ & Australia & JX840345 & GenBank \\
\hline G. curtisii & $\begin{array}{l}\text { CBS } \\
100131\end{array}$ & $\mathrm{NC}$, USA & JQ781848 & Zhou et al. 2015 \\
\hline G. curtisii & $\begin{array}{l}\text { CBS } \\
100132\end{array}$ & $\mathrm{NC}, \mathrm{USA}$ & KJ143967 & Zhou et al. 2015 \\
\hline $\begin{array}{l}\text { G. destructans } \\
\text { M.P.A. Coetzee, } \\
\text { Marinc. \& M.J. } \\
\text { Wingf. }\end{array}$ & $\begin{array}{l}\text { CMW4367 } \\
0\end{array}$ & South Africa & KR183856 & $\begin{array}{l}\text { Coetzee et al. } \\
2015\end{array}$ \\
\hline G. destructans & $\begin{array}{l}\text { CMW4367 } \\
1\end{array}$ & South Africa & KR183857 & $\begin{array}{l}\text { Coetzee et al. } \\
2015\end{array}$ \\
\hline $\begin{array}{l}\text { G. ellipsoideum } \\
\text { Hapuar., T.C. Wen \& } \\
\text { K.D. Hyde, sp. nov. } \\
\text { (holotype) }\end{array}$ & $\begin{array}{l}\text { GACP1408 } \\
0966\end{array}$ & Hainan, China & MH106867 & This study \\
\hline G. ellipsoideum & $\begin{array}{l}\text { GACP1408 } \\
0968\end{array}$ & Hainan, China & MH106868 & This study \\
\hline G. ellipsoideum & $\begin{array}{l}\text { GACP1408 } \\
1215\end{array}$ & Hainan, China & MH106886 & This study \\
\hline G. flexipes Pat. & $\begin{array}{l}\text { GACP1404 } \\
5450\end{array}$ & Hainan, China & MH106873 & This study \\
\hline G. flexipes & $\begin{array}{l}\text { Wei5200 } \\
\text { (IFP) }\end{array}$ & Hainan, China & JN383978 & $\begin{array}{l}\text { Cao \& Yuan } \\
2013\end{array}$ \\
\hline G. flexipes & $\begin{array}{l}\text { Wei5494 } \\
\text { (IFP) }\end{array}$ & Hainan, China & JN383979 & $\begin{array}{l}\text { Cao \& Yuan } \\
2013\end{array}$ \\
\hline $\begin{array}{l}\text { G. fornicatum (Fr.) } \\
\text { Pat. }\end{array}$ & $\begin{array}{l}\text { BCRC3537 } \\
4\end{array}$ & Taiwan & JX840349 & Wang et al. 2014 \\
\hline G. fornicatum & $\begin{array}{l}\text { TNM- } \\
\text { F0009926 }\end{array}$ & China & JX840348 & Wang et al. 2014 \\
\hline $\begin{array}{l}\text { G. gibbosum (Cooke) } \\
\text { Pat. }\end{array}$ & XSD-34 & Unknown & EU273513 & GenBank \\
\hline G. gibbosum & $\begin{array}{l}\text { GACP1407 } \\
0442\end{array}$ & Hainan, China & MH106880 & This study \\
\hline G. gibbosum & $\begin{array}{l}\text { SFC201509 } \\
18-08\end{array}$ & Korea & KY364271 & $\begin{array}{l}\text { Jargalmaa et al. } \\
2017\end{array}$ \\
\hline
\end{tabular}


Table 2 Continued.

\begin{tabular}{|c|c|c|c|c|}
\hline Species & $\begin{array}{l}\text { Voucher/ } \\
\text { strain }\end{array}$ & Origin & $\begin{array}{l}\text { GenBank } \\
\text { accession } \\
\text { number }\end{array}$ & Reference \\
\hline $\begin{array}{l}\text { G. hoehnelianum } \\
\text { Bres. }\end{array}$ & Dai12096 & China & KU219989 & Song et al. 2016 \\
\hline G. hoehnelianum & Dai11995 & China & KU219988 & Song et al. 2016 \\
\hline G. hoehnelianum & $\begin{array}{l}\text { GACP1408 } \\
0913\end{array}$ & Hainan, China & MH106881 & This study \\
\hline $\begin{array}{l}\text { G. leucocontextum } \\
\text { T.H. Li, W.Q. Deng, } \\
\text { Dong M. Wang \& } \\
\text { H.P. Hu }\end{array}$ & $\begin{array}{l}\text { GDGM443 } \\
03\end{array}$ & China & KJ027607 & Li et al. 2015 \\
\hline G. leucocontextum & TL-2013 & China & KF011548 & Li et al. 2015 \\
\hline $\begin{array}{l}\text { G. lipsiense sensu } \\
\text { auct. }\end{array}$ & $\begin{array}{l}\text { FIN } \\
131 R 610\end{array}$ & Unknown & EF060004 & Terho et al. 2007 \\
\hline G. lipsiense & $\begin{array}{l}\text { NOR74/67/ } \\
5\end{array}$ & Unknown & EF060002 & Terho et al. 2007 \\
\hline $\begin{array}{l}\text { G. lobatum (Cooke) } \\
\text { G.F. Atk. }\end{array}$ & JV 0402/24 & Unknown & KF605677 & GenBank \\
\hline G. lobatum & $\begin{array}{l}\text { JV } \\
\text { 1212/10J }\end{array}$ & Unknown & KF605676 & GenBank \\
\hline $\begin{array}{l}\text { G. lucidum (Curtis) } \\
\text { P. Karst. }\end{array}$ & $\begin{array}{l}\text { Dai1 } 1593 \\
\text { (IFP) }\end{array}$ & Finland & JQ781852 & Cao et al. 2012 \\
\hline G. lucidum & K175217 & UK & KJ143911 & Zhou et al. 2015 \\
\hline G. lucidum & $\begin{array}{l}\text { MT2610 } \\
\text { (BRNM) }\end{array}$ & Czech Republic & KJ143912 & Zhou et al. 2015 \\
\hline G. lucidum & $\begin{array}{l}\text { Dai2272 } \\
\text { (IFP) }\end{array}$ & Sweden & JQ781851 & Cao et al. 2012 \\
\hline G. lucidum & $\begin{array}{l}\text { HKÁS7108 } \\
8\end{array}$ & Yunnan, China & KC222321 & $\begin{array}{l}\text { Yang \& Feng } \\
2013\end{array}$ \\
\hline G. lucidum & GICN04 & Italy & AM906058 & $\begin{array}{l}\text { Guglielmo et al. } \\
2008\end{array}$ \\
\hline G. lucidum & GIT099 & Italy & AM269773 & $\begin{array}{l}\text { Guglielmo et al. } \\
2008\end{array}$ \\
\hline G. lucidum & $\begin{array}{l}\text { Rivoire } \\
4195\end{array}$ & France & KJ143909 & Zhou et al. 2015 \\
\hline $\begin{array}{l}\text { G. mastoporum Lév.) } \\
\text { Pat. }\end{array}$ & $\begin{array}{l}\text { TNM- } \\
\text { F0018835 }\end{array}$ & China & JX840351 & Wang et al. 2012 \\
\hline G. mastoporum & $\begin{array}{l}\text { TNM- } \\
\text { F0018838 }\end{array}$ & China & JX840350 & Wang et al. 2012 \\
\hline G. mastoporum & Gma-1 & Unknown & GU213486 & GenBank \\
\hline $\begin{array}{l}\text { G. mizoramense } \\
\text { Zothanz., Blanchette, } \\
\text { Held \& C.W. Barnes }\end{array}$ & UMN-MZ4 & India & KY643750 & Crous et al. 2017 \\
\hline G. mizoramense & UMN-MZ5 & India & KY643751 & Crous et al. 2017 \\
\hline $\begin{array}{l}\text { G. multipileum Ding } \\
\text { Hou }\end{array}$ & $\begin{array}{l}\text { CWN0467 } \\
0\end{array}$ & Taiwan, China & KJ143913 & Wang et al. 2012 \\
\hline G. multipileum & Dai9447 & Hainan, China & KJ143914 & Wang et al. 2012 \\
\hline
\end{tabular}


Table 2 Continued.

\begin{tabular}{|c|c|c|c|c|}
\hline Species & $\begin{array}{l}\text { Voucher/ } \\
\text { strain }\end{array}$ & Origin & $\begin{array}{l}\text { GenBank } \\
\text { accession } \\
\text { number }\end{array}$ & Reference \\
\hline $\begin{array}{l}\text { G. multiplicatum } \\
\text { (Mont.) Pat. }\end{array}$ & $\begin{array}{l}\text { GACP1408 } \\
1328\end{array}$ & Hainan, China & MH106879 & This study \\
\hline G. multiplicatum & Dai 13710 & China & KU572489 & Xing et al. 2016 \\
\hline $\begin{array}{l}\text { G. orbiforme (Fr.) } \\
\text { Ryvarden }\end{array}$ & $\begin{array}{l}\text { GACP1408 } \\
0918\end{array}$ & Hainan, China & MH106878 & This study \\
\hline G. orbiforme & $\begin{array}{l}\text { GACP1408 } \\
1239\end{array}$ & Hainan, China & MH106876 & This study \\
\hline G. orbiforme & $\begin{array}{l}\text { GACP1408 } \\
1108\end{array}$ & Hainan, China & MH106874 & This study \\
\hline G. orbiforme & $\begin{array}{l}\text { GACP1408 } \\
1329\end{array}$ & Hainan, China & MH106877 & This study \\
\hline G. orbiforme & $\begin{array}{l}\text { GACP1408 } \\
1235\end{array}$ & Hainan, China & MH106875 & This study \\
\hline $\begin{array}{l}\text { G. oregonense } \\
\text { Murrill } 1908\end{array}$ & $\begin{array}{l}\text { CBS } \\
265.88\end{array}$ & OR, USA & JQ781875 & Zhou et al. 2015 \\
\hline G. oregonense & $\begin{array}{l}\text { CBS } \\
266.88\end{array}$ & OR, USA & JQ781876 & Zhou et al. 2015 \\
\hline G. parvulum Murrill & URM83343 & Brazil & JQ618246 & $\begin{array}{l}\text { Correia de Lima } \\
\text { et al. } 2014\end{array}$ \\
\hline G. parvulum & URM80765 & Brazil & JX310822 & $\begin{array}{l}\text { Correia de Lima } \\
\text { et al. } 2014\end{array}$ \\
\hline G. pfeifferi Bres. & $\begin{array}{l}\mathrm{K}(\mathrm{M}) 12081 \\
8\end{array}$ & UK & AY884185 & $\begin{array}{l}\text { Park et al. } \\
2012\end{array}$ \\
\hline G. pfeifferi & $\begin{array}{l}874 \text { (CAS- } \\
\text { IM) }\end{array}$ & Czech Republic & AM906059 & $\begin{array}{l}\text { Guglielmo et al. } \\
2008\end{array}$ \\
\hline $\begin{array}{l}\text { G. philippii (Bres. \& } \\
\text { Henn. ex Sacc.) Bres. }\end{array}$ & E7098 & $\begin{array}{l}\text { Indonesia, Sumatra } \\
\text { islands }\end{array}$ & AJ536662 & GenBank \\
\hline G. philippii & E7425 & Malaysia, Selangor & AJ608713 & GenBank \\
\hline G. resinaceum Boud. & DP107 & Italy & AM906064 & $\begin{array}{l}\text { Guglielmo et al. } \\
2008\end{array}$ \\
\hline G. resinaceum & GR102 & India & GU451247 & $\begin{array}{l}\text { Mohanty et al. } \\
2011\end{array}$ \\
\hline G. resinaceum & $\begin{array}{l}\text { GACP } \\
\text { HNU02 }\end{array}$ & Hainan, China & MH106883 & This study \\
\hline G. ryvardenii & $\begin{array}{l}\text { HKAS5805 } \\
3\end{array}$ & Cameroon & HM138671 & $\begin{array}{l}\text { Kinge \& Mih } \\
2011\end{array}$ \\
\hline $\begin{array}{l}\text { G. sinense J.D. Zhao, } \\
\text { L.W. Hsu \& X.Q. } \\
\text { Zhang }\end{array}$ & $\begin{array}{l}\text { GACP1408 } \\
1236\end{array}$ & Hainan, China & MH106882 & This study \\
\hline G. sinense & GS175 & Unknown & DQ425014 & Su et al. 2007 \\
\hline G. sinense & GS92 & Unknown & DQ424982 & Su et al. 2007 \\
\hline $\begin{array}{l}\text { G. steyaertanum B.J. } \\
\text { Sm. \& Sivasith. }\end{array}$ & II-121-1 & Indonesia & KJ654427 & Glen et al. 2014 \\
\hline G. steyaertanum & $\begin{array}{l}\text { 6-WN-15- } \\
\text { M-A }\end{array}$ & Indonesia & KJ654459 & Glen et al. 2014 \\
\hline
\end{tabular}


Table 2 Continued.

\begin{tabular}{|c|c|c|c|c|}
\hline Species & $\begin{array}{l}\text { Voucher/ } \\
\text { strain }\end{array}$ & Origin & $\begin{array}{l}\text { GenBank } \\
\text { accession } \\
\text { number }\end{array}$ & Reference \\
\hline $\begin{array}{l}\text { G. subresinosum } \\
\text { (Murrill) C.J. } \\
\text { Humphrey }\end{array}$ & $\begin{array}{l}\text { GACP1408 } \\
1663\end{array}$ & Hainan, China & MH106885 & This study \\
\hline G. subresinosum & $3 C-29$ & Indonesia & KJ654406 & Glen et al. 2014 \\
\hline G. subresinosum & 5-D-3-D-26 & Indonesia & KJ654467 & Glen et al. 2014 \\
\hline $\begin{array}{l}\text { G. tropicum (Jungh.) } \\
\text { Bres. }\end{array}$ & $\begin{array}{l}\text { BCRC } 3712 \\
2 \text { (TNM) }\end{array}$ & Taiwan, China & EU021457 & Wang et al. 2009 \\
\hline G. tropicum & Dai9724 & China & JQ781879 & Cao et al. 2012 \\
\hline G. tropicum & $\begin{array}{l}\text { GACP1408 } \\
1518\end{array}$ & Hainan, China & MH106884 & This study \\
\hline G. tsugae Murrill & $\begin{array}{l}\text { Dai3937 } \\
\text { (IFP) }\end{array}$ & China & JQ781853 & Cao et al. 2012 \\
\hline G. tsugae & $\begin{array}{l}12751 b \\
(B J F C)\end{array}$ & USA(CT) & KJ143919 & Zhou et al. 2015 \\
\hline G. tsugae & $\begin{array}{l}\text { AFTOL- } \\
\text { ID771 }\end{array}$ & Unknown & DQ206985 & $\begin{array}{l}\text { Matheny et al. } \\
2007\end{array}$ \\
\hline G. tsugae & Dai12760 & USA & KJ143920 & Zhou et al. 2015 \\
\hline $\begin{array}{l}\text { G. wiiroense E.C. } \\
\text { Otto, Blanchette, } \\
\text { C.W. Barnes \& Held }\end{array}$ & $\begin{array}{l}\text { UMN-21- } \\
\text { GHA }\end{array}$ & Ghana & KT952363 & Crous et al. 2015 \\
\hline G. wiiroense & $\begin{array}{l}\text { UMN-20- } \\
\text { GHA }\end{array}$ & Ghana & KT952361 & Crous et al. 2015 \\
\hline $\begin{array}{l}\text { Coriolopsis trogii } \\
\text { (Berk.) Domański }\end{array}$ & $\begin{array}{l}\text { TC-02 } \\
\text { (TNM) }\end{array}$ & USA & JN164993 & $\begin{array}{l}\text { Jargalmaa et al. } \\
2017\end{array}$ \\
\hline
\end{tabular}

* BJFC, Beijing Forestry University; BRNM, Moravian Museum in Brno; CBS, Centraalbureau voor Schimmelcultures, Utrecht, the Netherlands; CAS-IM, Academy of Sciences of Czech Republic Institute of Microbiology Department of Experimental Mycology, Videnska, Czech Republic; CGMC China General Microbiological Culture Collection Center, Chinese Academy of Sciences; Di. Va.P.R.A, Department of Exploitation and Protection of the Agricultural and Forestry resources, University of Torino, Grugliasco (Italy); FFPRI ,the Forest Products Research Institute; FWP, Fungi of West Pakistan, Jardin Botanique de Belgique, Belgium; GACP, Herbarium of Guizhou Agricultural College (Guizhou University), Guiyang City, Guizhou, China; HMAS, Mycological Herbarium of the Institute of Microbiology, Chinese Academy of Sciences, HKAS; Kunming Institute of Botany, Chinese Academy of hidden flowers herbarium; IFP, Institute of Applied Ecology, Chinese Academy of Sciences; JV, The private herbarium of Josef Vlasak; KEW, the Royal Botanical Garden, Kew, Surrey, UK; KTCC, Korean Type Culture Collection; NY, the New York Botanical Garden; Rivoire, the private collection of Bernard Rivoire; RYV, Herbarium of Leif Ryvarden, Oslo, Norway; TNM, the Herbarium of the National Museum of Natural Science.

* Type specimens are in bold.

\section{Results}

\section{Phylogeny}

The tree topologies obtained from ML and BY were identical. Therefore, only the ML tree is shown (Fig. 2). The 89 collections of Amauroderma and Ganoderma clustered in ten clades 
(Amauroderma rugosum, G. applanatum, G. hoehnelianum, G. lucidum species complex, G. orbiforme, G. resinaceum, G. sinense, G. subresinosum, laccate Ganoderma and non-laccate Ganoderma) (Fig. 2). Our collections from Hainan Province, China clustered with all other Amauroderma and Ganoderma species, including the holotypes ( $G$. destructans, G. wiiroense, $G$. ryvardenii, and G. mizoramense) and the paratype (G. wiiroense) in well-supported clades (Fig. 2). Furthermore, the new species $G$. ellipsoideum clustered in the non-laccate Ganoderma species clade with high support $(\mathrm{BS}=91 \%, \mathrm{BPP}=1.0)$.

Sequences, A. rugosum (GACP14080910 and GACP14080952), G. australe (GACP14081134 and GACP14081671), G. flexipes (GACP HNU5450), G. gibbosum (GACP14070442), G. hoehnelianum (GACP14080913), G. multiplicatum (GACP14081328), G. orbiforme (GACP14080918, GACP14081108, GACP14081235, GACP14081239 and GACP14081329), G. resinaceum (GACP HNU02), G. sinense (GACP14081236), G. subresinosum (GACP14081663) and G. tropicum (GACP14081518) obtained from collections, clustered in wellsupported clades forming monophyletic groups with, A. rugosum $(\mathrm{BS}=99 \%, \mathrm{BPP}=1.0), G$. australe $(\mathrm{BS}=100 \%, \mathrm{BPP}=1.0)$, G. flexipes $(\mathrm{BS}=97 \%$, $\mathrm{BPP}=0.98)$, G. gibbosum $(\mathrm{BS}=73 \%$, $\mathrm{BPP}=0.97)$, G. hoehnelianum $(\mathrm{BS}=100 \%, \mathrm{BPP}=1.0)$, G. multiplicatum $(\mathrm{BS}=100 \%, \mathrm{BPP}=1)$, $G$. orbiforme $(\mathrm{BS}=99 \%, \mathrm{BPP}=0.99), G$. resinaceum $(\mathrm{BS}=95 \%, \mathrm{BPP}=1), G$. sinense $(\mathrm{BS}=$ $100 \%, \mathrm{BPP}=0.99)$, G. subresinosum $(\mathrm{BS}=100 \%, \mathrm{BPP}=1.0)$ and G. tropicum $(\mathrm{BS}=100 \%$, $\mathrm{BPP}=1.0$ ), respectively (Fig. 2).

Ganoderma lucidum sequences from Europe (Dai2272, GIT099, Dai11593, MT2610, BR4195 and K175217) and China (HKAS71088), G. tsugae sequences from China (Dai3937) and USA (12751b and Dai12760), G. leucocontextum sequences from China (GDGM44303 and TL2013) and $G$. oregonense sequences from USA (CBS265.88 and CBS266.88) clustered in the $G$. lucidum species complex clade $(\mathrm{BS}=96 \%, \mathrm{BPP}=1)$ (Fig. 2). Ganoderma lipsiense sequences (NOR74/67/5, FIN131R610) (= G. applanatum) with two other G. applanatum sequences from China (Dai8924) and Europe (K(M) 120829) clustered in a well-supported G. applanatum clade, forming a monophyletic group $(\mathrm{BS}=99 \%, \mathrm{BPP}=1)(\mathrm{Fig} .2)$. The Ganoderma resinaceum (GACP HNU02) sequence obtained from collections from Hainan Province, together with G. resinaceum sequences from India (GR102) and Italy (DP107) attained from GenBank, clustered in the wellsupported G. resinaceum clade $(\mathrm{BS}=95 \%, \mathrm{BPP}=1)($ Fig. 2$)$. Therefore, we can conclude that Asian and European $G$. resinaceum species are phylogenetically similar even they have different morphological characteristics. Stalpers (1978) believed G. resinaceum is the correct name for the fungus described as G. lucidum and few researchers considered the numerous names as synonyms of G. resinaceum (Steyaert 1980, Ryvarden 1985). Moreover, it was believed that based on molecular data, G. resinaceum is a species complex (Moncalvo et al. 1995a). Later, it was found that $G$. resinaceum could not be distinguished phylogenetically from G. lucidum (Hong \& Jung 2004). However, Mohanty et al. (2011) has mentioned Ganoderma resinaceum to be distinct from G. lucidum and later, more researchers have suggested that G. resinaceum differed from G. lucidum (Cao et al. 2012, Zhou et al. 2015). Ganoderma hoehnelianum (GACP14080913) sequence obtained from our study, together with $G$. hoehnelianum sequences from China (Dai12096 and Dai11995) retrieved from GenBank, clustered in the well-supported G. hoehnelianum clade (BS = $100 \%$, BPP $=1.0$ ). Furthermore, Ganoderma hoehnelianum groups in a sister clade to $G$. resinaceum (Fig. 2).

Ganoderma curtisii $(\mathrm{BS}=100 \%, \mathrm{BPP}=1.0), G$. destructans $(\mathrm{BS}=99 \%, \mathrm{BPP}=0.95), G$. flexipes $(\mathrm{BS}=97 \%, \mathrm{BPP}=0.98), G$. mizoramense $(\mathrm{BS}=100 \%, \mathrm{BPP}=1.0)$, G. multipileum $(\mathrm{BS}=$ $74 \%, \mathrm{BPP}=0.95)$, G. multiplicatum $(\mathrm{BS}=100 \%$, $\mathrm{BPP}=1.0)$, G. parvulum $(\mathrm{BS}=100 \%, \mathrm{BPP}=$ 1.0), G. philippii $(\mathrm{BS}=100 \%, \mathrm{BPP}=1.0)$, G. steyaertianum $(\mathrm{BS}=98 \%$, $\mathrm{BPP}=1.0)$, G. tropicum $(\mathrm{BS}=100 \%, \mathrm{BPP}=1.0)$ and $G$. wiiroense $(\mathrm{BS}=100 \%, \mathrm{BPP}=1.0)$ clustered together in laccate Ganoderma species clade (Fig. 2). Ganoderma tropicum sequence (GACP14081518) from collections from Hainan Province, together with G. tropicum sequences (BCRC37122 and Dai9724) from China obtained from GenBank, clustered in the well-supported G. tropicum clade forming a monophyletic group $(\mathrm{BS}=100 \%, \mathrm{BPP}=1.0)($ Fig. 2). Previous phylogenetic evidence 
indicates that G. tropicum is a distinct species (Cao et al. 2012, Wang et al. 2012, Yang \& Feng 2013, Zhou et al. 2015) and this species can be widely found across subtropical and tropical Asia (Moncalvo \& Ryvarden 1997). Some researchers have shown in their phylogenies that G. tropicum is phylogenically more similar to G. multipileum (Wang et al. 2012, Cao et al. 2012). In our studies, G. tropicum resembles G. multipileum in morphology and habitat even though they are distinct species as Wang et al. (2009) mentioned previously. Ganoderma flexipes sequence (GACP14045450) obtained from collections from Hainan Province, together with G. flexipes sequences from China (Wei5200 and Wei5494) attained from GenBank, clustered in the wellsupported $G$. flexipes clade (BS $=100 \%$, BPP $=1.0$ ) (Fig. 2). Ganoderma flexipes clustered with $G$. wiiroense species originated from Ghana and further, they group in a sister clade to G. philippii from Malaysia. With the aid of molecular evidence many researchers reported G. flexipes species in China are more similar to G. multipileum and G. tropicum species found in China (Cao et al. 2012, Yang \& Feng 2013, Zhou et al. 2015). Our study here confirmed the same opinion. Ganoderma multiplicatum sequence (GACP14081328) obtained from collections from Hainan Province, together with $G$. multiplicatum sequences (Dai13710) from China retrieved from GenBank, clustered in the well-supported G. multiplicatum clade forming a monophyletic group (BS $=100 \%$, $\mathrm{BPP}=1.0)$ (Fig. 2).

Ganoderma adspersum $(\mathrm{BS}=100 \%$, BPP $=1.0)), G$. australe $(100 \%$, BPP $=1.0), G$. ellipsoideum $(\mathrm{BS}=91 \%, \mathrm{BPP}=1.0)$, G. gibbosum $(\mathrm{BS}=73 \%, \mathrm{BPP}=0.97)$, G. lobatum $(\mathrm{BS}=$ $99 \%, \mathrm{BPP}=1.0)$ and $G$. pfeifferi $(\mathrm{BS}=100 \%, \mathrm{BPP}=1.0)$ are clustered together in non-laccate Ganoderma species clade (Fig. 2). Ganoderma australe sequences (GACP14081671 and GACP14081134) obtained from our collections from Hainan Province, together with G. australe sequence (GDGM25831) retrieved from GenBank, clustered in the well-supported G. australe clade (100\%, BPP = 1.0) (Fig. 2). Ganoderma australe forms a support clade $(\mathrm{BS}=70 \%, \mathrm{BPP}=$ 0.95) with Ganoderma adspersum, G. ellipsoideum, G. gibbosum and G. lobatum. Ganoderma ellipsoideum is a new member of non laccate Ganoderma species and clustered in a separate clade from $G$. gibbosum with strong molecular support $(\mathrm{BS}=91 \%, \mathrm{BPP}=1)$ even they share some similar morphologies (Fig. 2). Ganoderma gibbosum sequence (GACP14070442) obtained from our study, together with G. gibbosum sequences (XSD-34 and SFC20150918-08) acquired from GenBank, clustered in the well-supported G. gibbosum clade forming a monophyletic group (BS = $73 \%, \mathrm{BPP}=0.97$ ) (Fig. 2).

Ganoderma orbiforme (GACP14080918, GACP14081108 GACP14081235, GACP14081239 and GACP14081329) sequences acquired from collections from Hainan Province, together with $G$. mastoporum (TNM F0018835, TNM F0018838 and Gma 1) and G. fornicatum sequences (TNM F0009926, BCRC35374) retrieved from GenBank clustered in the well-supported G. orbiforme clade (BS $=99 \%$, BPP $=0.99$ ) (Fig. 2). Wang et al. (2012) proposed G. orbiforme is the earliest valid name to use for the species G. mastoporum and G. fornicatum as previously described. Ganoderma sinense sequence (GACP14081236) obtained from our collections from Hainan Province, together with G. sinense sequences (GS175 and GS92) retrieved from GenBank, clustered in the well-supported $G$. sinense clade forming a monophyletic group $(\mathrm{BS}=100 \%, \mathrm{BPP}=$ 1.0) (Fig. 2). Furthermore, this species form a support clade with G. orbiforme and, however recognized as a species distinct from $G$. orbiforme.

Ganoderma subresinosum sequence (GACP14081663) acquired from our collections from Hainan Province, together with G. subresinosum sequences (3C-29 and 5-D-3-D-26) from Indonesia retrieved from GenBank, clustered in the well-supported G. subresinosum clade forming a monophyletic group $(\mathrm{BS}=100 \%, \mathrm{BPP}=0.99)$ (Fig. 2). Furthermore, G. subresinosum formed a distinct lineage from Ganoderma which supports the claim of Costa-Rezende et al. (2017) suggested, as Magoderna might be accepted at generic level. In the present phylogeny, Amauroderma formed a distinct lineage from Ganoderma. Amauroderma rugosum sequences (GACP14080910 and GACP14080952) obtained from our collections are clustered with A. rugosum sequences (Cui8882, Dai9553 and Zhou523) which retrieved from the GenBank in a wellsupported clade forming a monophyletic group $(\mathrm{BS}=99 \%$. BPP = 1) (Fig. 2). 


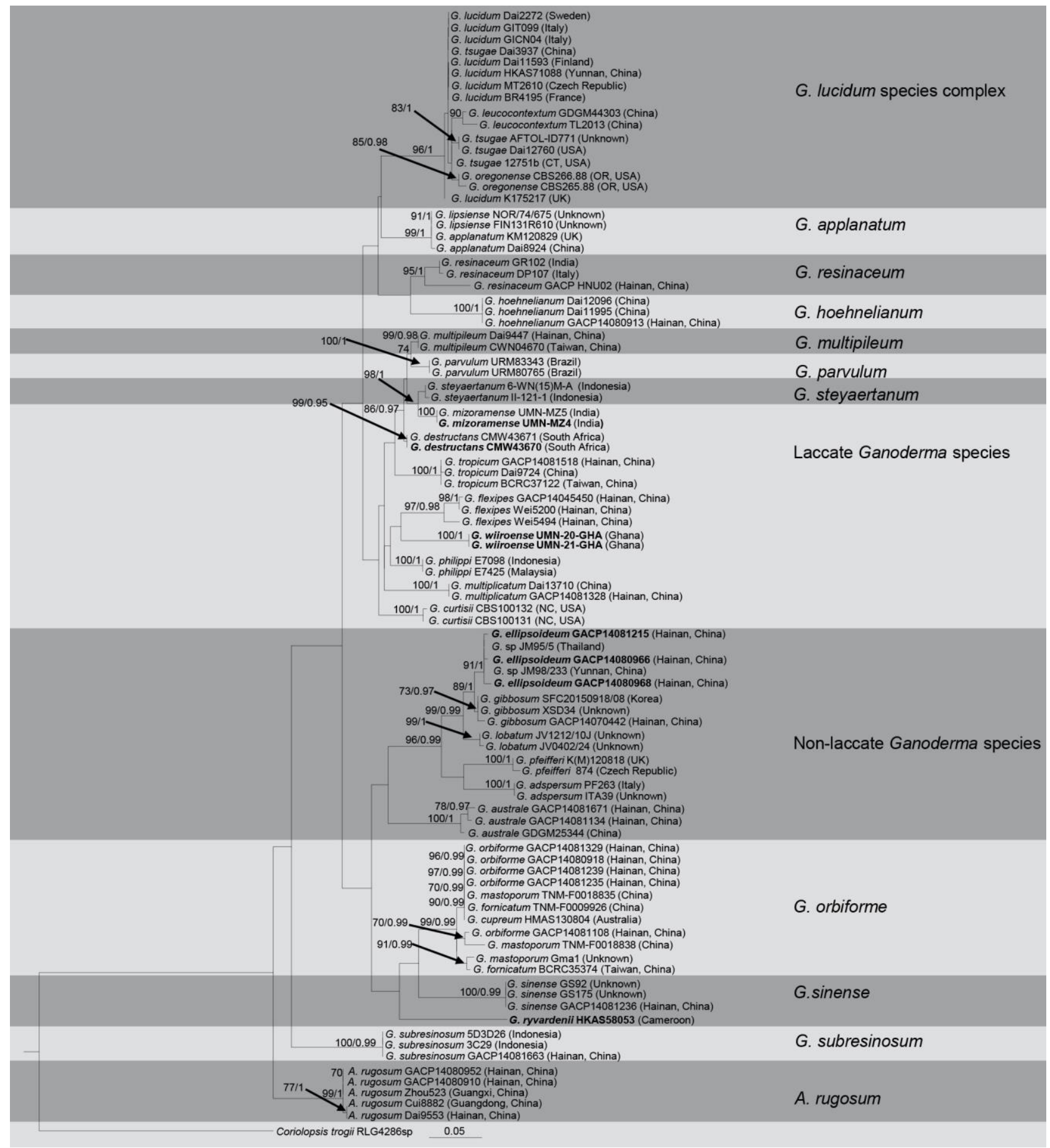

Figure 2 - Phylogram generated by maximum likelihood analysis of ITS sequences data. Bootstrap support values for maximum likelihood, greater than $70 \%$ and Posterior Probabilities from Bayesian Inference $\geq 0.95$ are given above branches. The tree was rooted with Coriolopsis trogii. The strain numbers and the countries of origin are mentioned after the species. Type species are indicated in black bold.

\section{Taxonomy}

\section{Key to the Genera}

1. Basidiospores conspicuously truncated at maturity, ellipsoid; basidiomes sessile to stipitate: if stipe present, never with a black zone between the stipe context and pileus context

Ganoderma 
1. Basidiospores round; basidiomes often stipitate; with a black zone between the stipe context and pileus context

Amauroderma

\section{Key to the Species}

1. Basidiomes laccate ...................................................................... 2

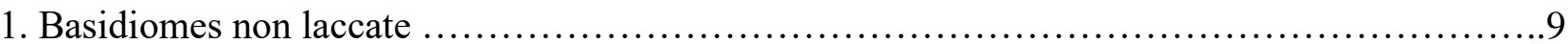

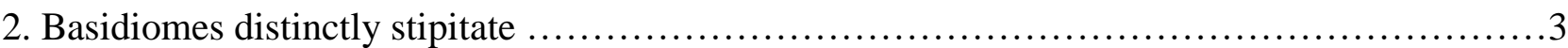

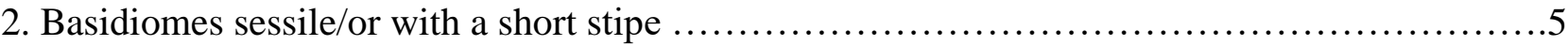

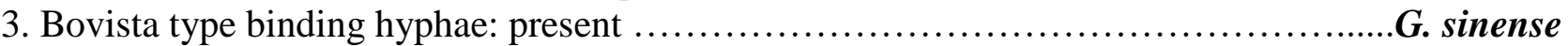

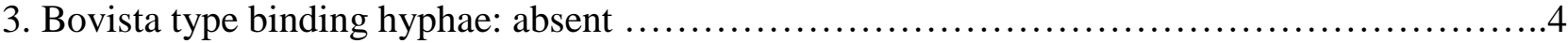

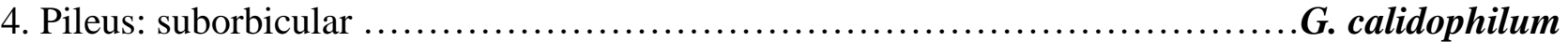

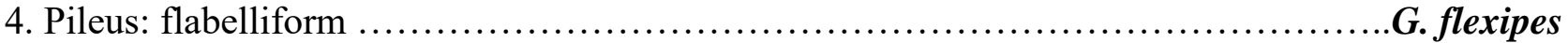

5. Differentiated swollen zone at the point of attachment: present ...........................6

5. Differentiated swollen zone at the point of attachment: absent ................... resinaceum

6. Pileus: suborbicular .....................................................................

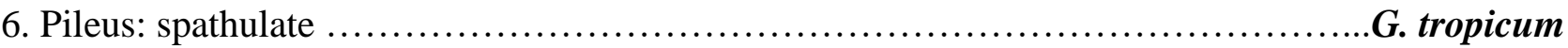

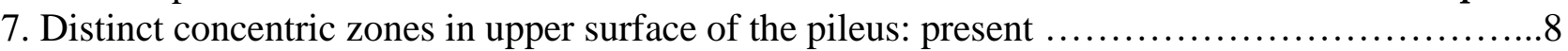

7. Distinct concentric zones in upper surface of the pileus: absent ................ subresinosum

8. Pileus colour: dark brown .................................................. hoehnelianum

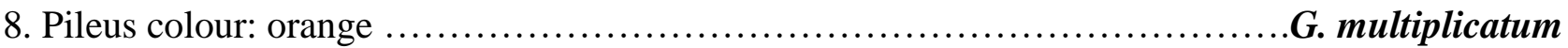

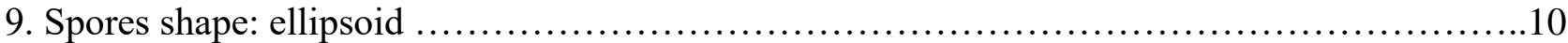

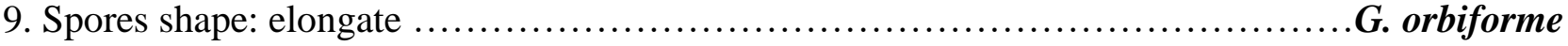

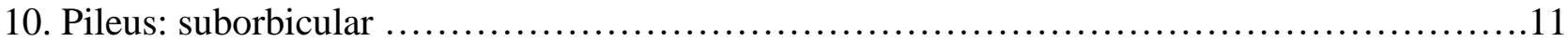

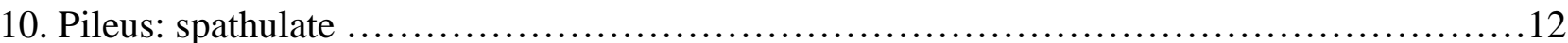

11. Spores length $>8 \mu \mathrm{m}$

G. australe

11. Spores length $<8 \mu \mathrm{m}$

G. applanatum

12. Margin in pileus: wavy

G. gibbosum

12. Margin in Pileus: soft

G. ellipsoideum

Genus Ganoderma P. Karst., 1881, Rev. Mycol. (Toulouse) 3, p. 17.

= Dendrophagus Murrill, Bull. Torrey bot. Club 32(9): 473 (1905)

= Elfvingia P. Karst., Bidr. Känn. Finl. Nat. Folk 48: 333 (1889)

= Friesia Lázaro Ibiza, Revista Real Acad. Ci. Madrid 14: 587 (1916)

= Ganoderma subgen. Trachyderma Imazeki, Bull. Tokyo Sci. Mus.1: 49 (1939)

= Magoderna Steyaert (1972)

= Tomophagus Murrill, Torreya 5: 197 (1905)

= Trachyderma (Imazeki) Imazeki, Bull. Gov. Forest Exp. Stn Tokyo 57: 97 (1952)

= Whitfordia Murrill (1908)

Description (from Ryvarden 2004).

Basidiomes annual or perennial, stipitate to sessile; pileus surface with a thick, dull cuticle or shiny and laccate with a thin cuticle or cuticle of clavate end cells; context cream coloured to dark purplish brown, soft and spongy to firm-fibrous; pore surface cream coloured, bruising brown, the pores regular, 4-7 per mm; tube layers single or stratified, pale to purplish brown; stipe when present central or lateral; hyphal system dimitic; generative hyphae with clamps; skeletal hyphae hyaline to brown, non-septate, often with long, tapering branches; basidia broadly ellipsoid, tapering abruptly at the base; cystidia absent; basidiospores broadly to narrowly ellipsoid with a truncate apex and apical germ pore, wall two-layered, endosporium brown and separated from the hyaline exosporium by inter-wall pillars, negative in Melzer's reagent, 7-30 $\mu \mathrm{m}$ long.

Type species: Ganoderma lucidum (Leyss: Fr.) Karst. 


\section{Annotated list of Ganoderma species in the Hainan Island}

\section{Ganoderma cf. applanatum}

Basidiome annual, sessile (usually with a distinctly contracted base), non-laccate, woody. Pileus 10-15 × 4-7 cm, sub-dimidiate, sub-applanate; upper surface hard, several layers thick, brown (6E4) to greyish brown (6E3), concentrically sulcate zones with turberculate bumps and ridges and rivulose depressions, radially rugose, with irregularly ruptured crust overlying the pellis; margin soft, 2-3 mm thick, rounded, concolourous with the rest of the pileus; lower surface greyish yellow (4B3) to light brown (6D5). Hymenophore up to $15 \mathrm{~mm}$ long, indistinctly stratose; pores initially whitish, light brown (6E4), 4-5 per mm; tubes circular or sub-circular. Context up to $3 \mathrm{~cm}$ thick, dry, duplex; lower layer greyish orange (6B3), fibrous/pithy, composed of coarse loose fibrils; upper layer greyish orange (6B3), woody. Basidiospores $(\mathrm{n}=50)(5.9-) 6.3-7.4-8.1(-8.8) \times$ (2.2-)4.2-5.8-6.3(-7) $\mu \mathrm{m}\left(Q_{m}=1.8, Q=1.1-3.4\right.$, with myxosporium). (3.1-)4.0-5.7-6.4(-7.0) $\times$ $(1.8-) 2.5-2.8-3.5(-4.4) \mu \mathrm{m}\left(Q_{m}=2.1, Q=1.4-2.9\right.$, without myxosporium), ellipsoid, sometimes truncate at one end, greyish orange (5B5) to light orange (5A5), eusporium bearing fine, short and distinct echinulae, overlaid by a hyaline myxosporium. Pileipellis a hymeniderm, brown (6E4) to greyish brown (6E3), composed of apically acanthus like branched cells, dextrinoid. Context trimitic; generative hyphae $(\mathrm{n}=30)(1.7-) 2.5-2.6-3.5(-3.6) \mu \mathrm{m}$ in width, thin-walled, colorless, with clamp connections; skeletal hyphae $(\mathrm{n}=30)(3.3-) 3.7-4.3-5.9(-6.4) \mu \mathrm{m}$ in width, brown (6E4) to greyish brown (6E3), dextrinoid, thick-walled; binding hyphae (n=30) (2.9-)3.5-3.7-4.4(-5.4) $\mu \mathrm{m}$ in width, brown (6E4) to greyish brown (6E3), thick-walled, frequently branched at apex, septate, intertwined with the skeletal hyphae (Fig. 3).

Habitat - On a decaying wood log, accompanied in humus rich soil with over heavily rotted litter on the ground.

Specimens examined - CHINA, Hainan Province, Jiangfengling Mountain, Coniferous rainforest, $18^{\circ} 44^{\prime} \mathrm{N}, 108^{\circ} 51^{\prime} \mathrm{E}$, elev. $550 \mathrm{~m}$, collection date unknown, collector X.L Wu (GACP HNU40), 9 August 2014, collector T.C Wen (GACP14080965, GACP14080967).

Notes - Ganoderma applanatum belongs in subgenus Elfvingia, which includes non-laccate species. It has a worldwide distribution and, is a central species in G. applanatum-G. australe complex. The type material originates from Europe and is preserved at the Rijksherbarium Leiden, Netherlands. This species is characterized by having; a thin, acute margin in pileus, unbranched terminal endings of skeletal hyphae, and (5.5-9.0) $\mu \mathrm{m}$ size, ellipsoid basidiospores (Pegler \& Young 1973, Ryvarden \& Gilbertson 1993, Leonard 1998, Wu \& Dai 2005). Our study macroscopically and microscopically agrees with the description of Pegler \& Young (1973). Ganoderma australe can be distinguished from G. applanatum by having larger basidiospores (Moncalvo \& Ryvarden 1997). Richter et al. (2015) mentioned that G. lipsiense also belongs in this complex, and has been treated by some researchers as the correct name for G. applanatum. However, the Nomenclature Committee for Fungi has approved the G. applanatum is the correct name for this taxon to conserve the basionym of G. applanatum, Boletus applanatus Pers. against the earlier name, Boletus lipsiensis Batsch. Furthermore, in our phylogenetic analysis European species of G. lipsiense and G. applanatum have been clustered in similar clade with $100 \%$ BS value (Fig. 2). Ganoderma applanatum can be distinguished chemotaxonomically by the presence of Benzopyranone derivatives such a Ganodermaaldehyde and Applanatins which have been isolated from specimens originating from both North America and Asia (Ming et al. 2002, Wang et al. 2007). This species was first described from China by Teng (1963) and later Zhao (1988) reexamined the specimen and synonymized with Ganoderma mirivelutinum J.D. Zhao. However, Wang et al. (2009) proved that holotype of G. mirivelutinum is morphologically distinct from Teng's specimen, but identical to Ganoderma applanatum var. laevisporum C.J. Humphrey \& Leus-Palo which characterized by basidiospores with smooth inner and outer wall layers. Our collections agree with the description provided by Ryvarden \& Gilbertson (1993). Moreover, we identify our specimens as Ganoderma cf. applanatum, since authentic type materials from the Northern temperate hemisphere were not included in this study. 

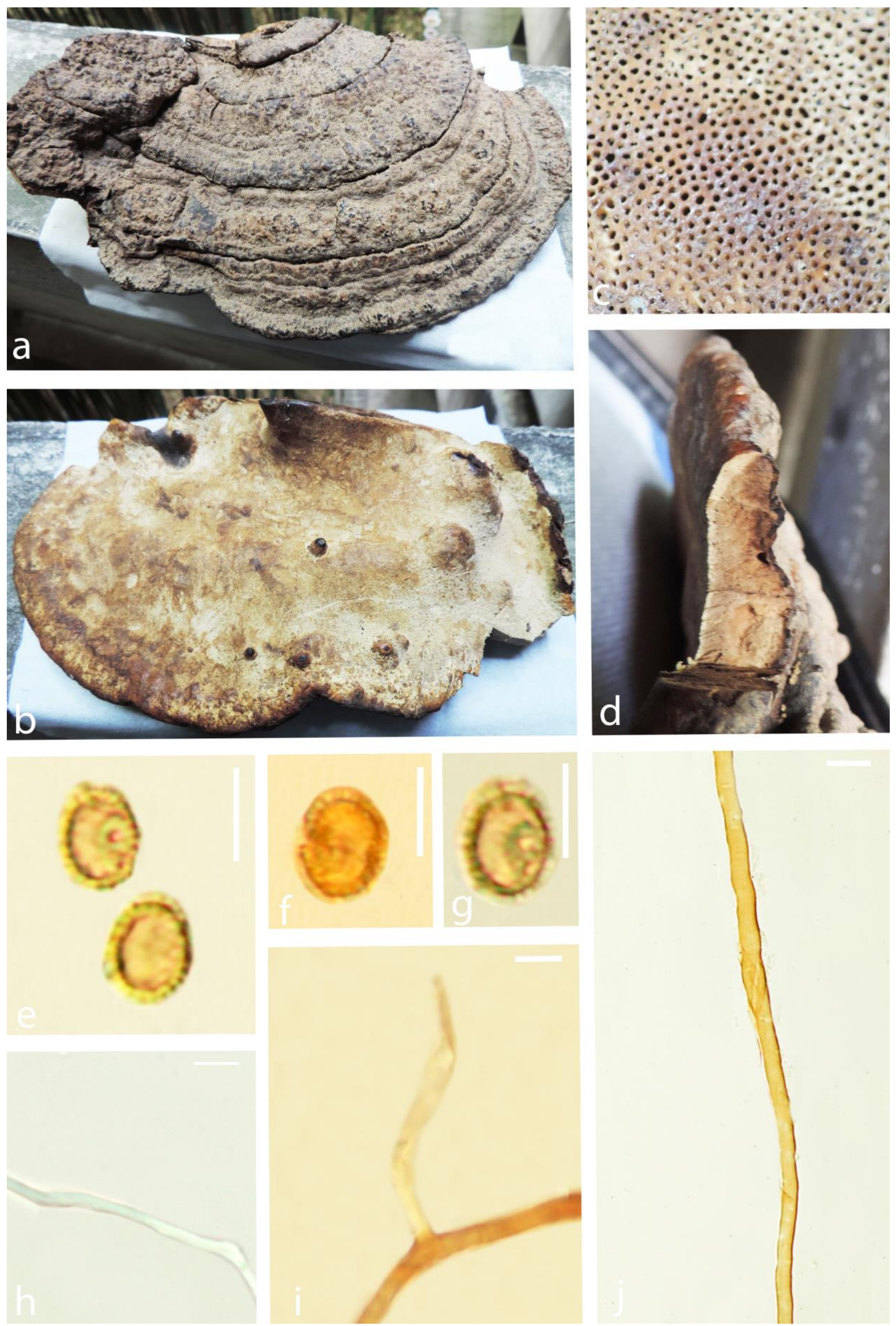

Figure 3 - Ganoderma cf. applanatum (GACP HNU40) a Upper surface. b Lower surface. c Pores in the lower surface $(4.5 \times)$. d Cut surface. e-g Spores $(100 \times)$. h Generative hyphae $(40 \times)$. i Binding hyphae (40x). j Skeletal hyphe (40x). Scale bars: $\mathrm{e}-\mathrm{g}=10 \mu \mathrm{m}, \mathrm{h}-\mathrm{j}=5 \mu \mathrm{m}$. 
Ganoderma australe (Fr.: Fr.) Pat., 1889, Bull. Soc. mycol. Fr. 5, p. 71

$\equiv$ Polyporus australis Fr.: Fr., 1828, Elench. Fung. 1, p. 108 (Type lost, initially described from Pacific Is.).

(See Index Fungorum for other synonyms)

Basidiome annual, sessile, non-laccate, woody. Pileus; 6-13 × 5.5-6 cm, sub-orbicular, plano-convex, applante, at center slightly swollen: upper surface brownish orange (6C4) to brown (6D4), distinctly concentrically sulcate, with irregularly ruptured crust overlying the pellis: margin soft, slightly lobate and concolorous with the pileus; lower surface yellowish white (4A2). Hymenophore up to $10 \mathrm{~mm}$ long, indistinctly stratose; pores initially yellowish white (4A2), later brown (6D6), 4-5 per $\mathrm{mm}$; pores circular or sub-circular. Context up to $1.5 \mathrm{~cm}$ thick, dry, duplex; lower layer, brown (6D6), fibrous/pithy, composed of coarse loose fibrils; upper layer dark brown (7F8), woody. Basidiospores $(\mathrm{n}=40)(6.1-) 7.6-9.2-10.8(-11.5) \times(4.7-) 5.3-7.6-7.9(-8.5) \mu \mathrm{m}$ $\left(Q_{m}=1.5, Q=0.9-2.6\right.$, with myxosporium). (4.9-)5.3-6.6-7.9(-8.5) $\times(3.1-) 3.4-4.2-5.1(-5.8) \mu \mathrm{m}$ $\left(Q_{m}=1.5, Q=0.9-2.9\right.$, without myxosporium), ellipsoid, brownish orange (6C8) to brown (6D8), with a brown eusporium bearing fine, short, and distinct echinulae, overlaid by a hyaline myxosporium. Pileipellis a hymeniderm, (6-28) $\mu \mathrm{m}$, brownish orange (6C8) to brown (6D8), composed of apically acanthus like branched cells, dextrinoid. Context trimitic; generative hyphae not observed; skeletal hyphae $(\mathrm{n}=30)(4.5-) 3.1-3.9-4.1(-4.8) \mu \mathrm{m}$, thick-walled, sometimes branched, brownish orange (6C8); binding hyphae $(\mathrm{n}=30)(3.5-) 4.2-5.6-5.8(-6.1) \mu \mathrm{m}$, thickwalled, branched, brownish orange (6C8) (Fig. 4).

Habitat - On a decaying wood log, accompanied in humus rich soil with over heavily rotted litter on the ground.

Specimens examined - CHINA, Hainan Province, Jiangfengling Mountain, Coniferous rainforest, $18^{\circ} 44^{\prime} \mathrm{N}, 108^{\circ} 5^{\prime}$ E, elev. $550 \mathrm{~m}, 11$ August 2014, collector T.C. Wen (GACP14081175, GACP14081134, GACP14081161, GACP14081671), collection date unknown, collector X.L Wu (GACP HNU42, GACP HNU5456).

Notes - Ganoderma australe (Fr.) Pat. 1889, belongs to G. applanatum-australe complex and can be distinguished from G. applanatum by having larger basidiospores (Moncalvo \& Ryvarden 1997). This species, common in the tropics, has never been recorded from Europe but was mistaken for the domestic G. adspersum (Smith \& Sivasithamparam 2000). The type specimen of G. australe cannot be found or is destroyed and the only material deposited in the Royal Botanic Gardens Kew is different from original collection (Ryvarden \& Gilbertson 1993). Currently, the only neotype available is from Europe. However, careful neotypification of G. australe is needed to resolve the problem that persists in taxonomy and geographical distribution (Kaliyaperumal \& Kalaichelvan 2008). Moncalvo \& Ryvarden (1997) considered Ganoderma annulare as an illegitimate name, since the basionym is illegitimate as nomenclaturly superfluous and earliest valid name to use is $G$. australe. Ganoderma tornatum and $G$. australe have been synonymized many times, but some researchers mistakenly prioritized $G$. tornatum over $G$. australe in publications. Furthermore, the concept of G. tornatum as a variety of G. applanatum was not accepted (Humphrey \& Leus 1931, Steyaert 1975a, b, Ryvarden \& Johnson 1980, Gilbertson \& Ryvarden 1986, Ryvarden \& Gilbertson 1993). This species was first introduced by Teng (1963) from China and after that several authors studies on this species (Tai 1979, Zhao et al. 1981, Zhao 1989, Bi et al. 1993, Teng 1996, Zhao \& Zhang 2000, Dai et al. 2011). Our collections agree with the descriptions provided by Moncalvo \& Ryvarden (1997).

Ganoderma calidophilum J.D. Zhao, L.W. Hsu \& X.Q. Zhang, Acta microbiol. Sin. 19(3): 270 (1979)

Basidiome annual, stipitate, laccate, corky. Pileus $4-7 \times 3-4.5 \mathrm{~cm}$, up to $1.5 \mathrm{~cm}$ thick at the base, sub-orbicular, rotund, upper surface; reddish brown (8E8) to dark brown (8F8), radially rugose with turberculate bumps and ridges and rivulose depressions, with irregularly ruptured crust overlying the pellis, margin; blunt to truncate, greyish orange (5B3), lower surface; light brown (7D5). Hymenophore up to $25 \mathrm{~mm}$ long, indistinctly stratose; pores initially greyish brown (7D3), 

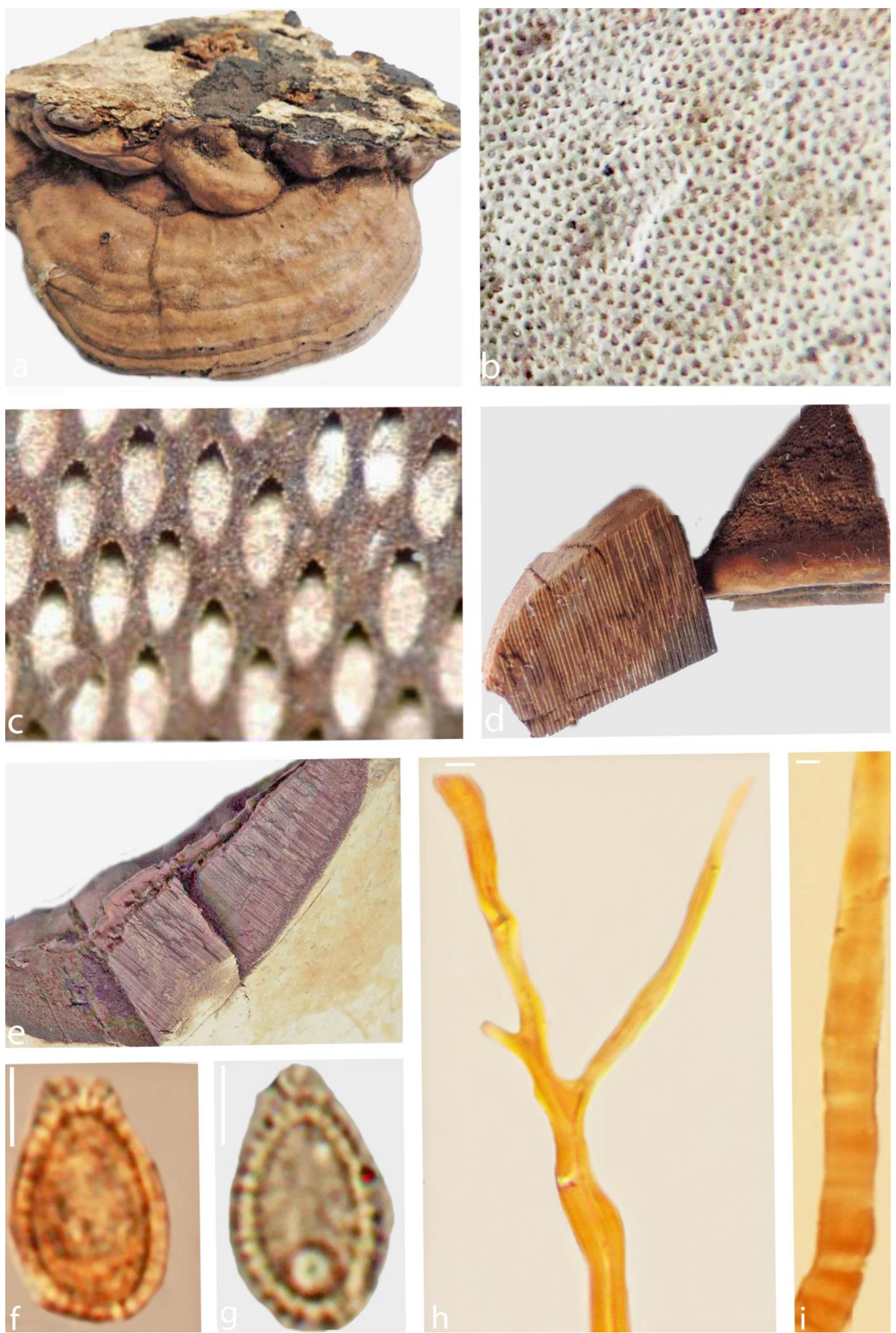

Figure 4 - Ganoderma australe (GACP14081671) a Upper surface. b Pores in the lower surface $(4.5 \times)$. c Pieces of the specimen. d Cut surface. e Cross section of the basidiome (4.5 $\times)$. $\mathrm{f}-\mathrm{g}$ Spores $(100 \times)$. h Generative hyphae $(100 \times)$. i Skeletal hyphae $(100 \times)$. Scale bars: $f-g=10 \mu \mathrm{m}, \mathrm{h}-\mathrm{i}=5$ $\mu \mathrm{m}$. 
bruising brown (8E8), pores circular or sub-circular, 5-6 per mm. Context up to $4 \mathrm{~mm}$ thick, duplex, dry; lower layer reddish brown (8E8), fibrous, composed of coarse loose fibrils; upper layer dark brown (8F8), corky to woody. Stipe eccentric, dorsally lateral to nearly dorsal, sub-cylindrical, dark brown (8F8), $6 \times 13 \mathrm{~cm}, 1.4 \mathrm{~cm}$ thick at the base. Basidiospores $(\mathrm{n}=40)(7.3-) 8.1-9.2-$ $13.8(14.6-) \times(-4.8) 5.3-7.6-7.9(-8.6) \mu \mathrm{m}\left(Q_{m}=1.5, Q=0.9-2.6\right.$ with myxosporium). (5.2-)6.1-6.6$9.6(-9.9) \times(3.5-) 4.9-5.1-5.9(-6.3) \mu \mathrm{m}\left(Q_{m}=1.5, Q=0.9-2.9\right.$, without myxosporium), broadly ellipsoid, light orange (5A5), brownish orange (6C8) to light brown (5A5), with a brown eusporium bearing fine, short, and distinct echinulae, overlaid by a hyaline myxosporium. Pileipellis a hymeniderm, brownish orange $(6 \mathrm{C} 8)$, clavate like cells, dextrinoid. Context trimitic; generative hyphae $(\mathrm{n}=30)(1.7-) 2.3-2.6-3.4(-3.9) \mu \mathrm{m}$, hyaline, thin-walled without clamp connections; skeletal hyphae $(\mathrm{n}=30)(3.1-) 4.5-5.4-6.5(-6.8) \mu \mathrm{m}$ thick-walled, nearly solid, sometimes branched, greyish brown (5B5) to brownish orange (6C8); binding hyphae $(n=30)(2.5-) 3.6-4.1-4.8(-5.4)$ $\mu \mathrm{m}$, thick-walled, branched, nearly solid, light orange (5A5) to brownish orange (6C8) (Fig. 5).

Habitat - On rotten wood, in dry dipterocarp forest and in upper mixed deciduous forest or growing up from soil.

Specimens examined - CHINA, Hainan Province, Diaoluoshan National Nature Reserve, $18^{\circ}$ $68^{\prime} \mathrm{N}, 109^{\circ}$ 95' E, elv. $1058 \mathrm{~m}$, collection date unknown, collector X.L. Wu (GACP HNU08, GACP HNU86).

Notes - Ganoderma calidophilum was introduced by Zhao et al. (1979) from Hainan Province, China as a stipitate wood-inhabiting polypore with a laccate pileus and broadly ellipsoid basidiospores. Later, many Chinese authors described this species from China (Zhao et al. 1981, Zhao 1989, Bi et al. 1993, Zhao \& Zhang 2000). Wu et al. (1999), Li et al. (2010) and Dai et al. (2011) included G. calidophilum in their polypore diversity checklists from Hainan Province. The observed morphological characters of G. calidophilum in this study, are similar with previous descriptions (Zhao et al. 1979, Bi et al. 1993) even we were unable to obtain molecular data from our $G$. calidophilum specimen. Wang \& Wu (2007) suggested that this species is a synonym of $G$. flexipes and Cao et al. (2012) subsequently followed this conclusion. However, present study confirms G. flexipes and G. calidophilum are morphologically different with pileus size, colour, context and basidiospore size (Bi et al. 1993, Wang \& Wu 2007). Hence, this species needs further studies with authentic type materials, fresh collections and suitable molecular markers.

Ganoderma ellipsoideum Hapuar., T.C. Wen \& K.D. Hyde, sp. nov.

Index Fungorum number: IF554384, Facesoffungi number: FoF04458

Etymology: refers to the basidiospore shape 'ellipsoid'

Holotype: GACP14080966

Basidiome annual, sessile (usually with a distinctly contracted base), non laccate, woody. Pileus 3$6.5 \times 4-5 \mathrm{~cm}$, up to $1.5 \mathrm{~cm}$ thick at the base, flabelliform, plano convex, applante, upper surface; hard, several layers thick, brownish orange (5C4) to yellowish brown (5E8) crust overlies pellis, not cracking, yellowish brown (5F8), containing fibrous pithy context, concentrically sulcate zones with turberculate bumps and ridges and rivulose depressions, alternating brownish orange $(5 \mathrm{C} 4)$ to yellowish brown (5E8) zones, differentiated zone at the point of attachment; margin $4 \mathrm{~mm}$ thick, rounded and concolorous with the pileus; lower surface white (4A1) to yellowish white (4A2). Hymenophore up to $10 \mathrm{~mm}$ long, indistinctly stratose; pores initially yellowish white (4A2), later yellowish brown (5D8) to brownish yellow (5C8), pores circular or sub-circular. Context up to 1.5 $\mathrm{cm}$ thick, dry, duplex; lower layer yellowish brown (5F8), pithy, composed of coarse loose fibrils, soft; upper layer dark brown (7F8), woody. Basidiospores $(n=50)(5.3-) 6.1-6.8-7.3(-7.8) \times(2.9-$ )3.7-4.2-4.6(-5.2) $\mu \mathrm{m}\left(Q_{m}=1.6, Q=1.2-2.1\right.$, with myxosporium) (3.6-)4.2-4.7-5.3(-6.2) $\times(1.8-$ )2.4-2.9-3.3(-3.8) $\mu \mathrm{m} \quad\left(Q_{m}=1.6, Q=0.9-2.6\right.$, without myxosporium), greyish orange (5B4), elongate to ellipsoid, with a brown eusporium bearing fine, short and distinct echinulae, overlaid by a hyaline myxosporium. Pileipellis a hymeniderm, yellowish brown (5D8) to brownish yellow (5C8), composed of apically acanthus like branched cells, dextrinoid. Context trimitic; generative hyphae $(\mathrm{n}=50)(0.6-) 1.1-1.3-2.7(-3.1) \mu \mathrm{m}$ in width, thin-walled, colorless; skeletal hyphae 
$(\mathrm{n}=100)(0.7) 1.2-1.6-3.3(3.8) \mu \mathrm{m}$ in width, greyish orange (5B3), thick-walled, sometimes branched; binding hyphae $(\mathrm{n}=75)(1.2-) 1.5-2.3-4.1(-4.8) \mu \mathrm{m}$ in width, greyish orange (5B3), thick-walled, branched, intertwined with the skeletal hyphae (Fig. 6).
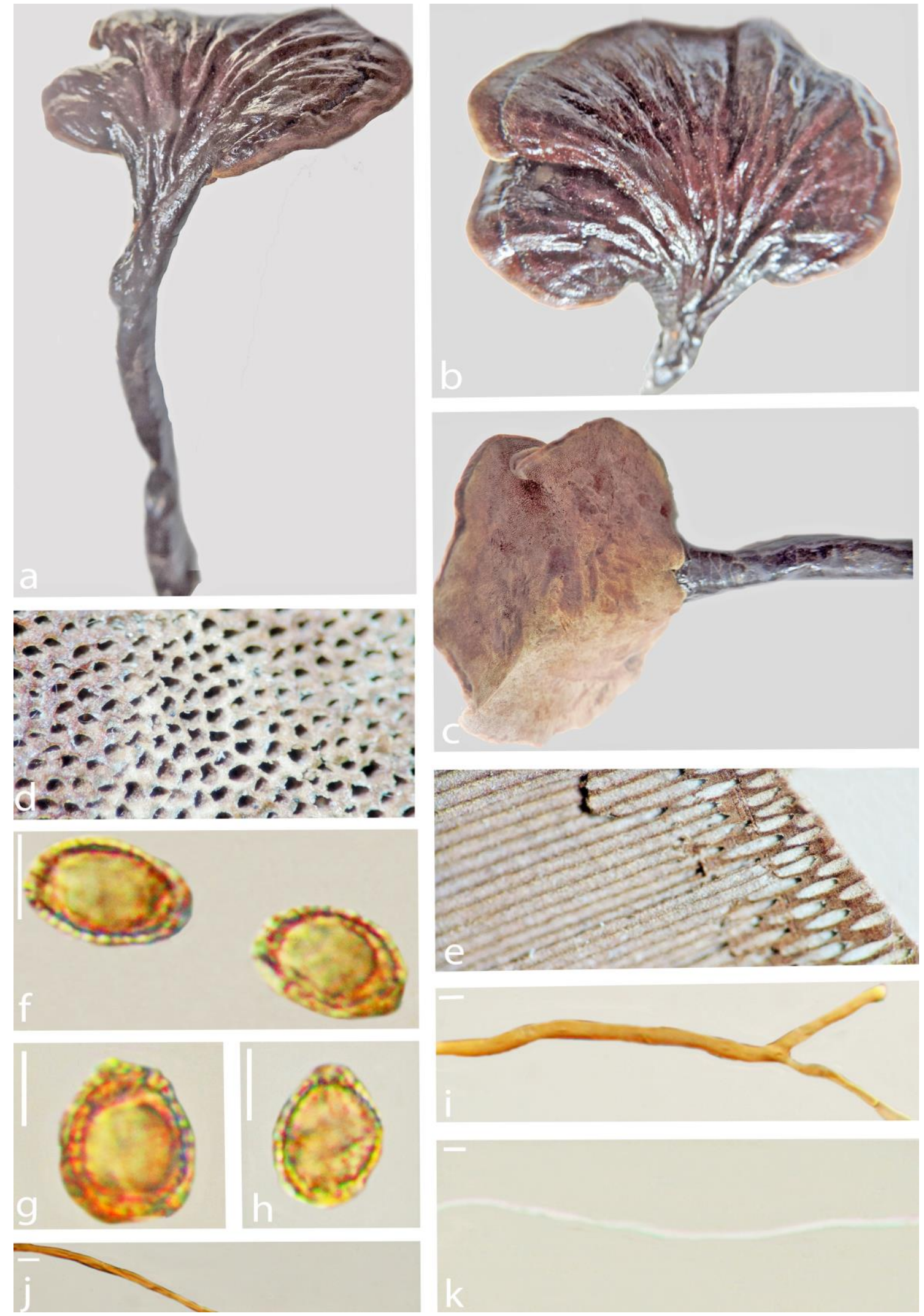

Figure 5 - Ganoderma calidophilum (GACP HNU86) a, b Upper surface. c Pores in the lower surface $(4.5 \times)$. d Lower surface. e Section of the context. f-i Spores $(100 \times)$. j Skeletal hyphae (100x). Scale bars: $\mathrm{f}-\mathrm{i}=10 \mu \mathrm{m}, \mathrm{j}-\mathrm{k}=5 \mu \mathrm{m}$. 
Habitat - On a decaying wood log, accompanied in humus rich soil with over heavily rotted litter in forest, mossy coniferous forests, producing basidiomata from late summer to late autumn. Currently only known from Hainan Province, China.

Material examined - CHINA, Hainan Province, Jiangfengling Mountain, $18^{\circ} 44^{\prime} \mathrm{N}, 108^{\circ} 51^{\prime}$ E, elev. 550 m, 9 August 2014, collector T.C. Wen (GACP14080966, holotype), (GACP14081215 and GACP14080968, paratypes).

Notes - Ganoderma ellipsoideum is a new member of genus Ganoderma (Fig. 6) and it is distinguished by ellipsoid spores $(6.1-7.3 \times 3.7-4.6) \mu \mathrm{m}$, with a brown eusporium bearing fine, short and distinct echinulae. It is clustered and morphologically similar with G. gibbosum (Blume $\&$ T. Nees) Pat., which is characterized by the sub-flabellate to sub-dimidiate, non laccate pileus, duplex, brown 4-5 mm thick context, trimitic hyphal system, brown, 7-14 mm long tubes, elongate to ellipsoid spores, 6.6-8.3 $\times 5-6 \mu \mathrm{m}$, smooth hyaline outer wall, echinulate inner wall (Bi et al. 1993). Furthermore, it clustered with unidentified Ganoderma species recorded from Thailand (JM95/5) and China (JM98/233) (description unavailable), which belong to the $G$ australe complex and the G. applanatum complex, respectively (Moncalvo \& Buchanan 2008). The species is currently only known from the type locality, Jiangfengling Mountain, Hainan, China.

Ganoderma flexipes Pat., Bull. Soc. mycol. Fr. 23(2): 75 (1907)

$=$ Fomes flexipes (Pat.) Sacc. \& Traverso, Syll. fung. (Abellini) 19: 710 (1910)

= Polyporus flexipes (Pat.) Lloyd, Mycol. Writ. 3 (Syn. Stip. Polyporoids): 104 (1912)

Basidiome annual, stipitate, laccate, corky. Pileus $1.5-4 \times 0.5-2.5 \mathrm{~cm}$, up to $0.2 \mathrm{~cm}$ thick at the base, flabelliform, rotund, upper surface; reddish brown (8E8), concentrically sulcate zones with turberculate bumps and ridges and rivulose depressions, with irregularly ruptured crust overlying the pellis, margin; soft, yellowish brown (5E8), lower surface; light brown (7D5). Hymenophore up to $10 \mathrm{~mm}$ long, indistinctly stratose; pores initially greyish brown (7D3), bruising brown (8E8), pores circular or sub-circular or isodiametric, 3-4 per mm. Context up to $4 \mathrm{~mm}$ thick, triplex, dry; lower layer reddish brown (8E8), fibrous, composed of coarse loose fibrils; upper layer dark brown (8F8), corky to woody. Stipe eccentric, dorsally lateral to nearly dorsal, sub-cylindrical, dark brown (8F8), $4 \times 7 \mathrm{~cm}, 0.4 \mathrm{~cm}$ thick at the base. Basidiospores $(\mathrm{n}=25)(9.5-) 9.2-10.2-11.5(-$ $12.2) \times(6.8-) 7.9-8.1-7.9(-8.4) \mu \mathrm{m}\left(Q_{m}=1.4, Q=0.9-2.1\right.$ with myxosporium $)$. (8.2-)8.1-8.5-9.6(9.9) $\times(3.2-) 4.9-5.5-5.9(-6.4) \mu \mathrm{m}\left(Q_{m}=1.4, Q=0.9-2.9\right.$, without myxosporium), ellipsoid, light orange (5A5), brownish orange (6C8) to light brown (5A5), with a brown eusporium bearing fine, short and distinct echinulae, overlaid by a hyaline myxosporium. Pileipellis a hymeniderm, brownish orange $(6 \mathrm{C} 8)$, clavate like cells, dextrinoid. Context trimitic; generative hyphae $(\mathrm{n}=30)$ (1.7-)2.3-2.6-3.4(-3.9) $\mu \mathrm{m}$, hyaline, thin-walled without clamp connections; skeletal hyphae $(\mathrm{n}=30)(3.1-) 4.5-5.4-6.5(-6.8) \mu \mathrm{m}$ thick-walled, nearly solid, sometimes branched, greyish brown (5B5) to brownish orange (6C8); binding hyphae $(\mathrm{n}=30)(2.5-) 3.6-4.1-4.8(-5.4) \mu \mathrm{m}$, thick-walled, branched, nearly solid, light orange (5A5) to brownish orange (6C8)(Fig. 7).

Habitat - On rotten wood, in dry dipterocarp forest and in upper mixed deciduous forest or growing up from soil.

Specimens examined - CHINA, Hainan Province, Jiangfengling Mountain, $18^{\circ} 44^{\prime} \mathrm{N}, 108^{\circ}$ 51' E, elev. $550 \mathrm{~m}$, collection date unknown, collector X.L. Wu (GACP HNU42, GACP HNU5450), 13 August 2014, collector T.C. Wen (GACP14081339).

Notes - Ganoderma flexipes was introduced by Patouillard (1907) from Vietnam and has been recorded from China, India, Nepal and Pakistan (Steyaert 1972). Many Chinese authors reported this species from China (Zhao et al. 1981, Zhao 1989, Zhao \& Zhang 2000, Wang \& Wu 2007). Ganoderma flexipes can easily be recognized by its small reddish brown pileus, long and thin stipe, reddish brown to dark brown context, and ellipsoid or ovoid basidiospores. Our collections fall within the range $(8-9.9-13 \times 5.5-6.5-8) \mu \mathrm{m}$, measured by Steyaert (1972) and fits that of the lectotype $(9-11 \times 6-7.5) \mu \mathrm{m}$, measured by Ryvarden (1983) for G. flexipes. Furthermore, the pore diameter and corky context composed of mostly fine and thick-walled 
hyphae, in the collections from Hainan Province resemble those of authenticated specimens and of the holotype (Steyaert 1972).
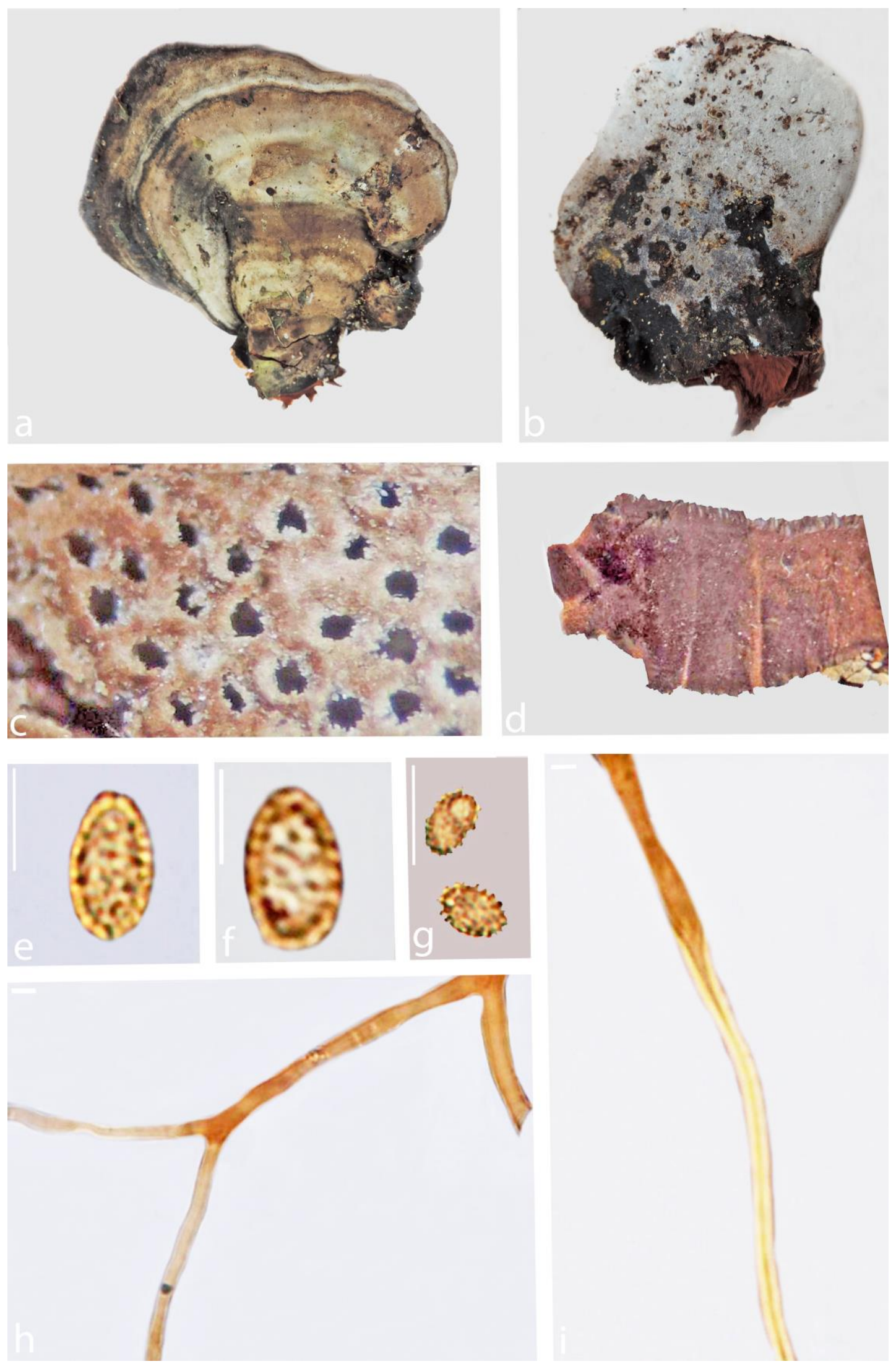

Figure 6 - Ganoderma ellipsoideum (GACP14080966, holotype) a Upper surface. b Lower surface. c Cut surface. $d$ Pores in the lower surface (4.5×). e Pieces of the specimen. $\mathrm{f}-\mathrm{i}$ Spores $(100 \times)$. j Skeletal hyphae $(100 \times)$. k Binding hyphae $(100 \times)$. Scale bars: $\mathrm{f}-\mathrm{i}=10 \mu \mathrm{m}, \mathrm{j}-\mathrm{k}=5 \mu \mathrm{m}$. 

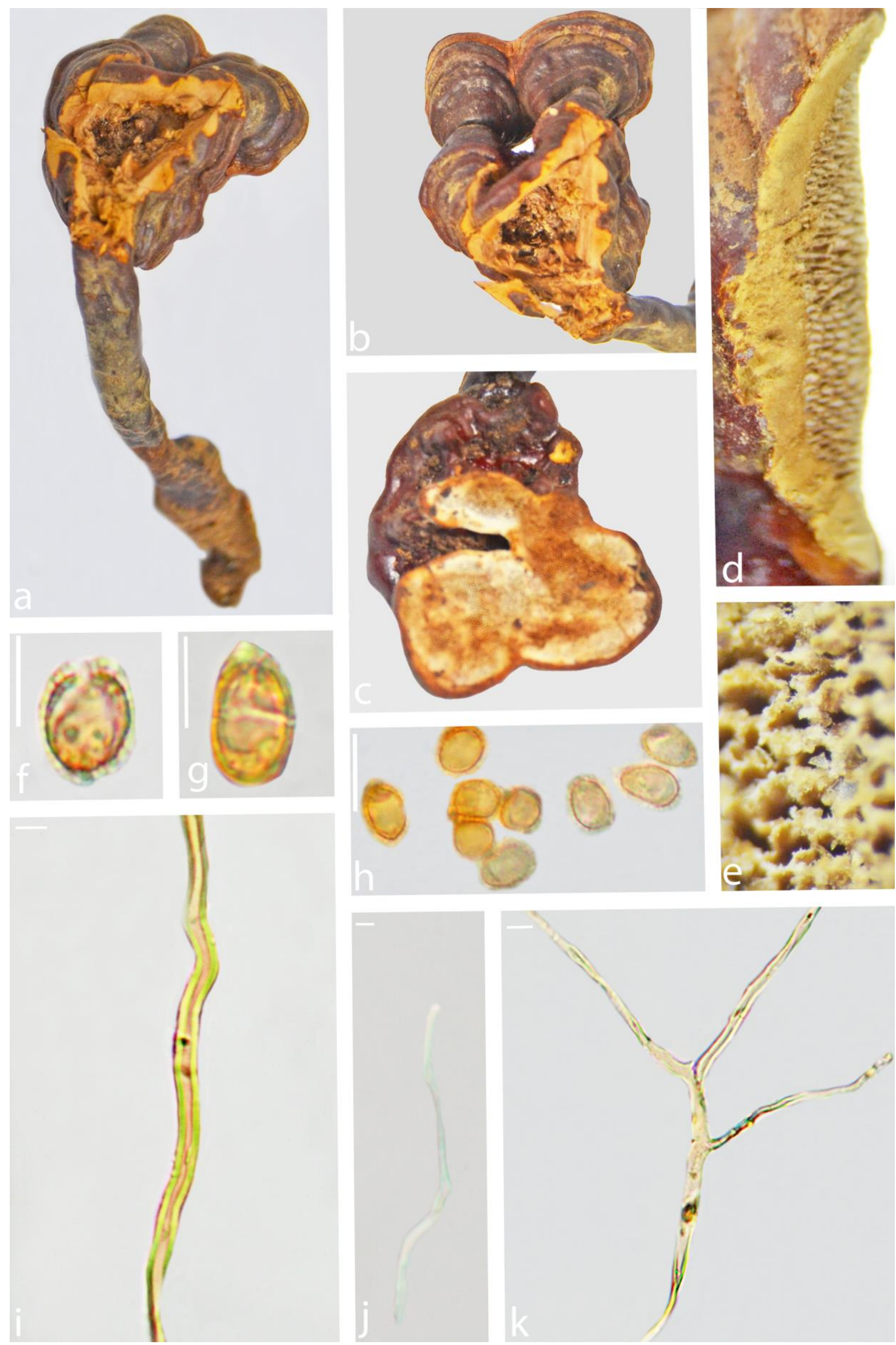

Figure 7 - Ganoderma flexipes (GACP HNU5450) a, b Upper surface. c Lower surface. d Cut surface. e Pores in the lower surface (5x). $\mathrm{f}-\mathrm{h}$ Spores $(100 \times)$. i Skeletal hyphae $(100 \times)$. j Generative hyphae $(40 \times)$. $k$ binding hyphae $(100 \times)$. Scale bars: $\mathrm{f}-\mathrm{h}=10 \mu \mathrm{m}, \mathrm{i}-\mathrm{k}=5 \mu \mathrm{m}$. 
Ganoderma gibbosum (Blume \& T. Nees) Pat., Ann. Jard. Bot. Buitenzorg, suppl. 1: 114 (1897) $=$ Polyporus gibbosus Blume \& T. Nees, Nov. Act. Academiae Caesareae LeopoldinoCarolinae Germanicae Naturae Curiosorum 13: 19, t. 4:1-4 (1826)

= Fomes amboinensis var. gibbosus (Blume \& T. Nees) Cooke, Grevillea 13 (68): 118 (1885)

= Fomes gibbosus (Blume \& T. Nees) Sacc. Syll. Fung. 6: 156 (1888)

= Scindalma gibbosum (Blume \& T. Nees) Kuntze, Revisio generum plantarum 3 (2): 518 (1898)

Basidiome annual, sessile (usually with a distinctly contracted base), non laccate, woody. Pileus 6-12 × 3-6 cm, up to $3 \mathrm{~cm}$ thick at the base, spathulate, upper surface; hard, several layers thick, light brown (6D5) to light brown (6D6), crust overlies the pellis, concentric zones with turberculate bumps and ridges and rivulose depressions; margin with numerous undulations and irregularities, wavy, $2 \mathrm{~mm}$ thick, concolorous with the pileus; lower surface light brown (5D4). Hymenophore up to $6 \mathrm{~mm}$ long, indistinctly stratose, light brown (5D4), pores circular or sub circular, 4-5 pores per mm. Context up to $3 \mathrm{~cm}$ thick, dry, duplex, lower layer; brown (6E8), pithy, composed of coarse loose fibrils, upper layer; dark brown (6F8), woody. Basidiospores $(\mathrm{n}=50)$ (4.3-)6.9-7.6-9.2(-10.5) $\times(3.8-) 4.6-5.6-5.7(-6.1) \mu \mathrm{m}\left(Q_{m}=1.7, Q=0.8-2.5\right.$, with myxosporium). $(3.6-) 4.8-6.0-7.6(-8.7) \times(2.0-) 2.7-3.5-4.5(-6.7) \quad \mu \mathrm{m} \quad\left(Q_{m}=1.7, \quad Q=0.8-3.2, \quad\right.$ without myxosporium), ellipsoid to elongate, brown (6D8) to light brown (6D6), eusporium bearing fine, short, and distinct echinulae, overlaid by a hyaline myxosporium, bitunicate. Pileipellis a hymeniderm, brown (6D8) to light brown (6D6), composed of apically acanthus like branched cells, dextrinoid. Context trimitic; generative hyphae $(\mathrm{n}=30)(1.3-) 1.6-2.1-2.7(-3.6) \mu \mathrm{m}$ in width, thin-walled, hyaline; skeletal hyphae $(\mathrm{n}=30)(4.0-) 4.8-4.7-5.2(-5.8) \mu \mathrm{m}$ in width, brown (6F8), dextrinoid, thick-walled; binding hyphae $(\mathrm{n}=30)(2.6-) 3.6-4.7-5.8(-6.1) \mu \mathrm{m}$ in width, brown (6F8), thick-walled, branched, intertwined the skeletal hyphae (Fig. 8).

Habitat - On rotten wood, in dry dipterocarp forest and in upper mixed deciduous forest or growing up from soil.

Specimens examined - CHINA, Hainan Province, Jiangfengling Mountain, $18^{\circ} 44^{\prime} \mathrm{N}, 108^{\circ}$ 51' E, elev. 550 m, collection date unknown, collector X.L. Wu (GACP HNU32), 15 August 2014, collector T.C. Wen (GACP14070442, GACP14081517).

Notes - Ganoderma gibbosum is known from Australia (Saccardo 1888), China (Teng 1963, Zhao et al. 1981, Zhao 1989, Bi et al. 1993, Zhao \& Zhang 2000), Indonesia (Java) and Vietnam (Parmasto 1986), but the location of the type is not known (Moncalvo \& Ryvarden 1997). Ganoderma gibbosum was considered to be subspecies of G. applanatum (Zhao 1989). However, G. gibbosum was renamed as G. incrassatum: a species which known only from Australia, based on the monophyletic origin and low level of sequence variation (Smith \& Sivasithamparam 2003). Wu et al. (1999), Li et al. (2010) and Dai et al. (2011) included G. gibbosum in their Polypore diversity checklists from Hainan Province. Our collections from Hainan Province agree well with the descriptions provided by Bi et al. (1993) and Zhao \& Zhang (2000).

Ganoderma hoehnelianum Bres. Annls mycol. 10(5): 502 (1912)

= Ganoderma shangsiense J.D. Zhao, Acta Mycol. Sin. 7(1): 17 (1988).

Basidiome annual, sessile (usually with a distinctly contracted base), laccate, woody. Pileus $3.1-5.4 \times 1.9-3.5 \mathrm{~cm}$, up to $1.5 \mathrm{~cm}$ thick at the base, clustered, suborbicular, plano concave, triquetrous to sub applanate; upper surface hard, several layers thick, with brown (6D6) crust overlies the pellis, containing fibrous pithy context, concentrically sulcate zones, alternating light brown (6D6) and dark brown (6F8) zones, differentiated zone at the point of attachment, margin; soft, $3 \mathrm{~mm}$ thick, rounded, yellowish white (4A2), lower surface; white (5A1). Hymenophore up to $5 \mathrm{~mm}$ long, indistinctly stratose, greyish orange (5B3), pores circular or sub circular. Context up to $1.5 \mathrm{~cm}$ thick, dry, triplex; lower layer brown (6F8) fibrous, composed of coarse loose fibrils, soft; middle layer dark brown (6E8); upper layer light brown (6D6), woody. Basidiospores $(\mathrm{n}=50)(9.4-$ )10.5-11.7-12.1(-12.5) × (9.4-) 9.7-10.8-11.1(-11.8) $\mu \mathrm{m} \quad\left(Q_{m}=1.1, \quad Q=0.9-1.2\right.$, with myxosporium), (8.9-)9.7-10.6-11.3(-11.6) × (7.2-)8.8-9.3-10.1(-10.5) $\mu \mathrm{m}\left(Q_{m}=1.1, Q=0.8-1.1\right.$, 
without myxosporium), broadly ovoid to subglobose, brown (6E8), with a brown eusporium bearing fine, short and distinct echinulae, overlaid by a hyaline myxosporium, bitunicate. Pileipellis a hymeniderm, light brown (6D6) to dark brown (6E8), composed of clavate cells, dextrinoid. Context trimitic; generative hyphae $(\mathrm{n}=100)(0.3-) 0.9-1.1-1.9(-2.8) \mu \mathrm{m}$ in width, thin-walled, hyaline; skeletal hyphae $(\mathrm{n}=40)(0.9-) 1.5-1.9-(-4.0) \mu \mathrm{m}$ in width, thick-walled, greyish orange (6B3); binding hyphae $(\mathrm{n}=50)(1.4-) 1.8-2.9-3.5(-5.6) \mu \mathrm{m}$ in width, thick-walled, branched, greyish orange (6B3), intertwined with skeletal hyphae (Fig. 9).

Habitat - On a decaying wood log, accompanied in humus rich soil with over heavily rotted litter on the ground, mossy temperate mixed coniferous forests. Producing basidiomata from summer to late autumn.

Specimens examined - CHINA, Hainan Province, Jiangfengling Mountain, Coniferous rainforest, $18^{\circ} 44^{\prime} \mathrm{N}, 108^{\circ} 51^{\prime} \mathrm{E}$, elev. $550 \mathrm{~m}, 9$ August 2014, collector T.C. Wen (GACP14080913, GACP14081635).

Notes - Ganoderma hoehnelianum was introduced by Bresadola (1912) from Java, Indonesia. The context color, basidiospore characteristics, and cuticular composition are key diagnostic features for the identification of G. hoehnelianum (Wang \& Wu 2010). The latter authors revealed, by examining the isotype, that $G$. hoehnelianum is an earlier name for Ganoderma shangsiense (Wang et al. 2005), a species originally described from China. This species was recorded as G. shangsiense in the Hainan Province polypore diversity checklists provided by Li et al. (2010) and Dai et al. (2011). Our collections from Hainan Province agree well with the descriptions provided by Bresadola (1912) and Wang \& Wu (2010).

Ganoderma multiplicatum (Mont.) Pat., Bull. Soc. mycol. Fr. 5(2, 3): 74 (1889)

$\equiv$ Polyporus multiplicatus Mont. (1854)

(See Index Fungorum for synonyms)

Basidiome annual, sessile (usually with a distinctly contracted base), strongly laccate, woody. Pileus $6-9 \times 3.5-5 \mathrm{~cm}$, up to $3 \mathrm{~cm}$ thick at the base, sub-orbicular, plano convex, sub applante; upper surface hard, several layers thick, orange (6D8) to brown (7E8), crust overlies the pellis, containing fibrous pithy context, swollen differentiated zone at the point of attachment; margin soft or having irregularities, $1 \mathrm{~cm}$ thick, rounded, white (5A1); lower surface white (5A1) to orange (5B2). Hymenophore up to $4 \mathrm{~mm}$ long, indistinctly stratose, white (5A1) to orange (5B2), pores circular or sub circular or isodiametric. Context up to $3 \mathrm{~cm}$ thick, dry, duplex; lower layer brown (7E8), fibrous, composed of coarse loose fibrils, soft; upper layer pale orange (5A3), woody. Basidiospores $(\mathrm{n}=30)(4.8-) 5.9-7.1-8.3(-9.9) \times(3.3-) 6.6-4.3-8.3(-9.6) \mu \mathrm{m}\left(Q_{m}=1.6, Q=1.2-2.0\right.$, with myxosporium). (3.8-)4.5-5.3-6.2(-7.2) × (1.8-)2.3-2.6-3.5(-3.8) $\mu \mathrm{m}\left(Q_{m}=1.3, Q=1.3-3.8\right.$, without myxosporium), broadly ellipsoid to elongate, greyish orange (5B5) to brown (6E8), eusporium bearing fine, short, and distinct echinulae, overlaid by a hyaline myxosporium, bitunicate. Pileipellis a hymeniderm, greyish orange (5B5) to brown (6E8), composed of apically acanthus like branched cells, dextrinoid. Context dimitic; skeletal hyphae $(n=30)(2.6-) 2.9-3.4-$ $3.8(-4.2) \mu \mathrm{m}$ in width, light brown (6D4), thick walled, sometimes branched; binding hyphae $(\mathrm{n}=30)(1.2-) 2.1-2.6-3.3(-3.7) \mu \mathrm{m}$ in width, light brown (6D4), thick walled, branched, intertwined the skeletal hyphae (Fig. 10).

Habitat - On a decaying wood log, accompanied in humus rich soil with over heavily rotted litter on the ground, mossy temperate mixed coniferous forests. Producing basidiomata from summer to late autumn.

Specimens examined - CHINA, Hainan Province, Jiangfengling Mountain, Coniferous rainforest, $18^{\circ} 44 \mathrm{~N}, 108^{\circ} 51^{\prime} \mathrm{E}$, elev. $550 \mathrm{~m}, 13$ August 2014, collector T.C. Wen (GACP14081328, GACP14081330).

Notes - Ganoderma multiplicatum (Mont.) Pat. was originally collected in French Guyana (Moncalvo \& Ryvarden 1997) and is characterized by subglobose to broadly ellipsoid basidiospores $(7-8 \times 5-6 \mu \mathrm{m})$ with a dimitic or trimitic hyphal system. This species has described from China by many authors (Zhao et al. 1979, Zhao et al. 1981, Zhao 1989, Zhao \& Zhang 2000, 
Wang \& Wu 2007). The morphology of G. multiplicatum collections from Hainan Province agrees well with that of the holotype as described by Gottlieb \& Wright (1999a), Ryvarden (2000).
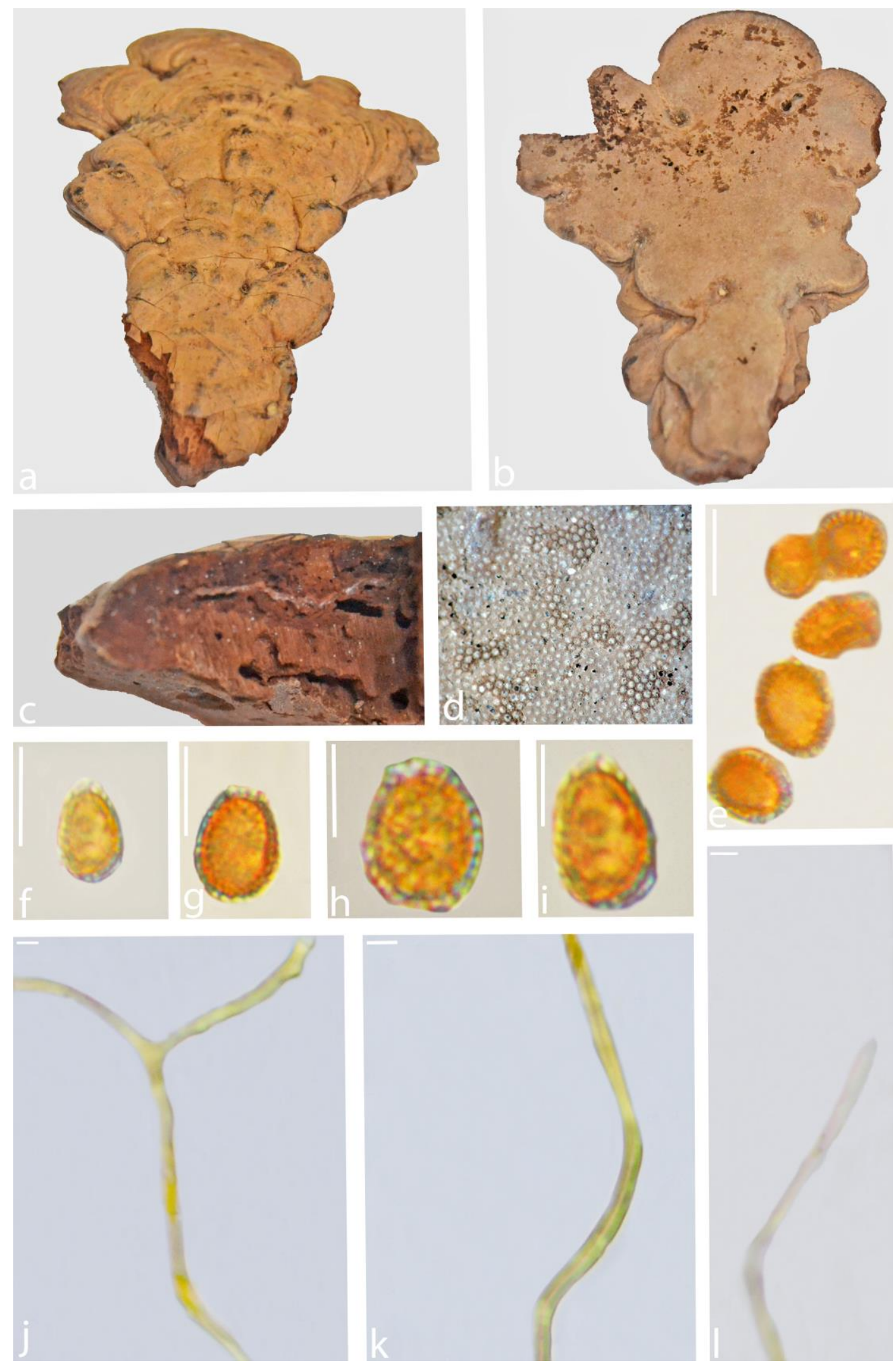

Figure 8 - Ganoderma gibbosum (GACP14070442) a Upper surface. b Lower surface. c Pores in the lower surface. $d$ Pores in the lower surface $(4.5 \times)$. e Cut surface. $f-j$ Spores $(100 \times)$. K Binding hyphae (100x). i Generative hyphae. m Skeletal hyphae $(100 \times)$. Scale bars: $\mathrm{f}-\mathrm{i}=10 \mu \mathrm{m}, \mathrm{j}-\mathrm{k}=5$ $\mu \mathrm{m}$. 

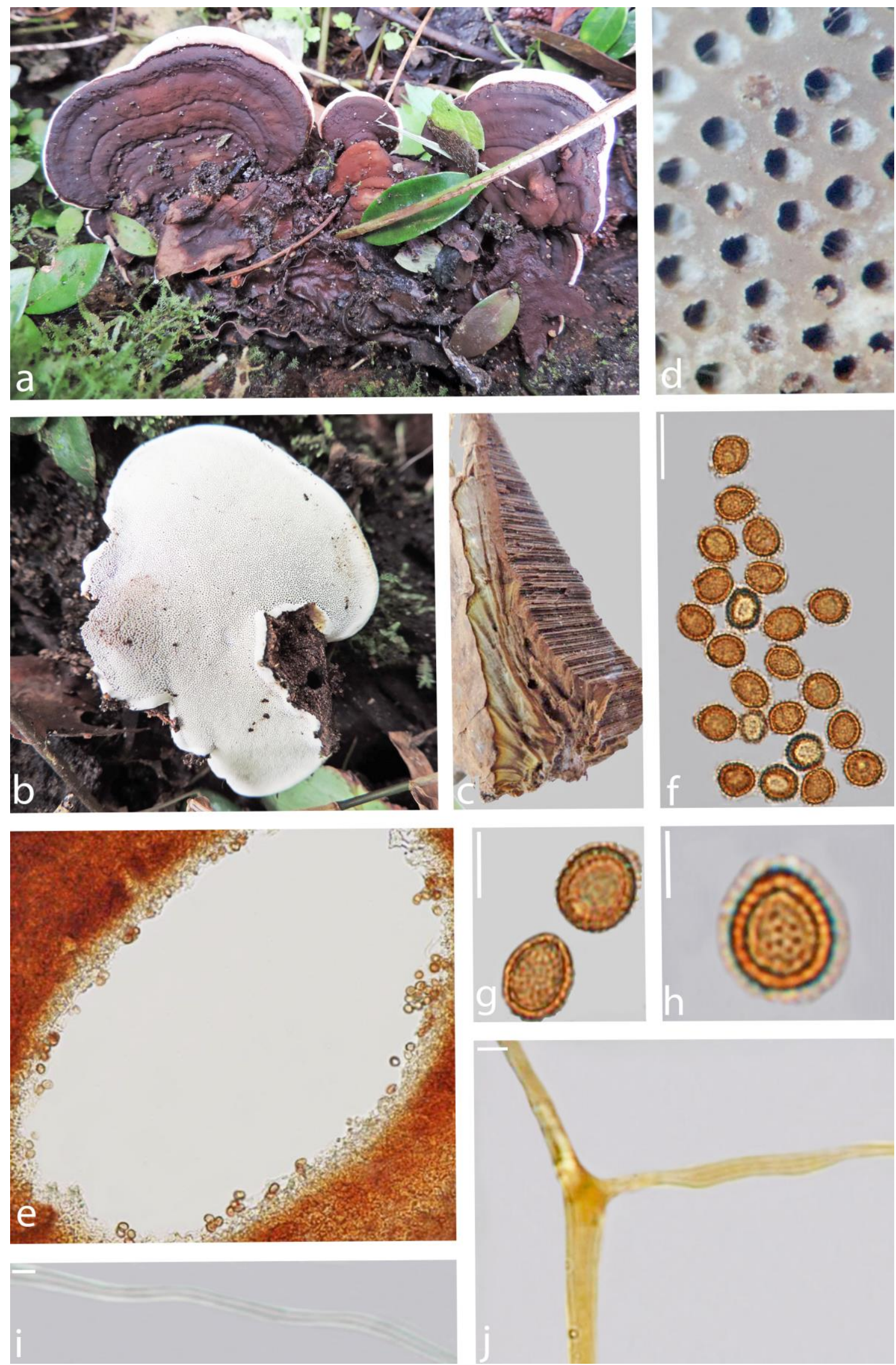

Figure 9 - Ganoderma hoehnelianum (GACP14080913). a Upper surface. b Lower surface. c Cut surface. $d$ Pores in the lower surface $(4.5 \times)$. e Transverse section of the specimen showing spores $(40 \times)$. $\mathrm{f}-\mathrm{h}$ Spores $(100 \times)$. i Generative hyphae $(100 \times)$. j Binding hyphae $(100 \times)$. Scale bars: $\mathrm{f}-\mathrm{h}=$ $10 \mu \mathrm{m}, \mathrm{i}-\mathrm{j}=5 \mu \mathrm{m}$. 

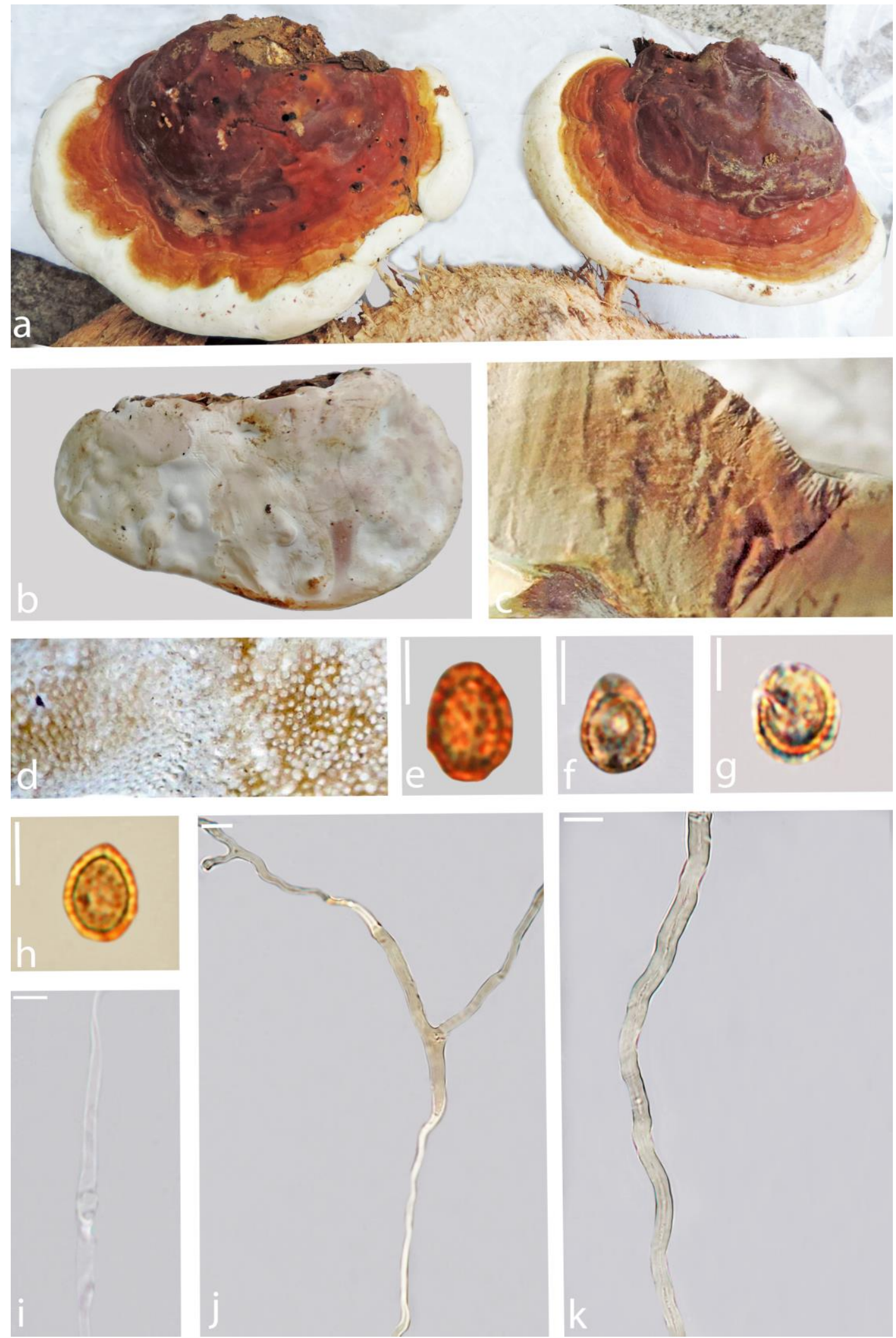

Figure 10 - Ganoderma multiplicatum (GACP14081328) a Upper surface. b Lower surface. c Pores in the lower surface $(4.5 \times)$. d Cut surface. e Pieces of the specimen. $f-i$ Spores $(100 \times)$. j Binding hyphae $(100 x)$. k Skeletal hyphae $(100 x)$. 1 Generative hyphae $(100 x)$. Scale bars: $f-i$ $=10 \mu \mathrm{m}, \mathrm{j}-1=5 \mu \mathrm{m}$.

This species has been considered as similar to G. chalceum (Corner 1983) and was synonymized as G. subamboinense (Ryvarden 2000). However, Correia de Lima et al. (2014) 
suggested that G. chalceum and G. subamboinense are not synonyms of G. multiplicatum on the basis of molecular data. Ganoderma multiplicatum was subsequently found in Africa (Steyaert 1980), Asia (Zhao 1989, Bhosle et al. 2010) and South America (Bolaños-Rojas et al. 2016).

Ganoderma orbiforme (Fr.) Ryvarden (as 'orbiformum') (2000)

$\equiv$ Polyporus orbiformis Fr. (1838)

= Ganoderma boninense Pat., Bull. Soc. mycol. Fr. 5(2, 3): 72 (1889)

= Ganoderma mastoporum (Lév.) Pat. [as 'malosporum'], Bull. Soc. mycol. Fr. 5(2, 3): 75 (1889)

= Ganoderma fornicatum (Fr.) Pat. sensu Imazeki, Bull. Tokyo Sci. Mus. 1: 47 (1939)

= Ganoderma cupreum (Cooke) Bres, Annls mycol. 9(3): 268 (1911)

= Ganoderma subtornatum Murrill, Bull. Torrey bot. Club 34: 477 (1907)

= Ganoderma densizonatum J.D. Zhao \& X.Q. Zhang, in Zhao, Zhang \& Xu, Acta Mycol. Sin. 5(2): 86 (1986)

= Ganoderma limushanense J.D. Zhao \& X.Q. Zhang, Acta Mycol. Sin. 5(4): 219 (1986)

(See Index Fungorum for other synonyms)

Basidiome annual, sessile (usually with a distinctly contracted base), non laccate, woody. Pileus 3-8 $\times 2.5-6 \mathrm{~cm}$, up to $2 \mathrm{~cm}$ thick at the base, suborbicular, plano convex, applanate, upper surface; hard, several layers thick, light brown (6D5), crust overlies the pellis, concentrically sulcate zones with turberculate bumps and rivulose depressions, differentiated zone at the point of attachment, radially rugose; margin with numerous undulations and irregularities, $3 \mathrm{~mm}$ thick, rounded and concolourous with the pileus; lower surface light brown (6D4). Hymenophore up to $3 \mathrm{~mm}$ long, indistinctly stratose, orange grey (6B2), pores circular or sub-circular. Context up to 2 cm thick, dry, duplex; lower layer dark brown (7F8), pithy, composed of coarse loose fibrils, soft; upper layer light brown (5D4), woody. Basidiospores $(\mathrm{n}=47)(6.9-) 7.6-8.3-10.3(-10.3) \times(3.6-$ 4.8-5.3-5.8(-5.7) $\mu \mathrm{m}\left(Q_{m}=1.8, Q=1.5-2.6\right.$, with myxosporium). (4.7-)5.8-6.5-7.8(-8.5) $\times(2.8-$ )3.2-3.4-4.3(-5.6) $\mu \mathrm{m}\left(Q_{m}=1.8, Q=1.5-2.6\right.$, without myxosporium), yellowish brown (5D8), elongate, eusporium bearing fine, short, and distinct echinulae, overlaid by a hyaline myxosporium, bitunicate. Pileipellis a hymeniderm, dark brown (7F8), composed of apically acanthus like branched cells, dextrinoid. Context trimitic; generative hyphae $(\mathrm{n}=30)(0.4-) 0.5-1.3-1.8(-2.6) \mu \mathrm{m}$ in width, thin-walled, hyaline; skeletal hyphae $(\mathrm{n}=30)(3.2-) 3.8-4.2-4.8(-5.2) \mu \mathrm{m}$ in width, light brown (5D6), thick-walled; binding hyphae $(\mathrm{n}=30)(1.3-) 1.1-1.5-2.6(-2.9) \mu \mathrm{m}$ in width, light brown (5D6), thick-walled, branched, intertwined the skeletal hyphae (Fig. 11).

Habitat - On a decaying wood log, accompanied in humus rich soil with over heavily rotted litter on the ground in forest, mossy temperate mixed coniferous forests, producing basidiomata from summer to late autumn.

Specimens examined - CHINA, Hainan Province, Jiangfengling Mountain, Coniferous rainforest, $18^{\circ} 44^{\prime} \mathrm{N}, 108^{\circ} 51^{\prime} \mathrm{E}$, elev. $550 \mathrm{~m}, 9$ August 2014, collector T.C. Wen; (GACP14080918, GACP14080953) 10 August 2014; (GACP14081069), 11 August 2014; (GACP14081108, GACP14081182, GACP14081184, GACP14081185), 12 August 2014; (GACP14081202, GACP14081232, GACP14081235, GACP14081239), 13 August 2014; (GACP4081310, GACP4081329, GACP14081333, GACP14081340), Wuzshishan Mountain, Coniferous rainforest, $18^{\circ} 53^{\prime} \mathrm{N}, 109^{\circ} 38^{\prime} \mathrm{E}$, elev. $1240 \mathrm{~m}, 12$ August 2014, collector T.C Wen; (GACP14081666).

Notes - Ganoderma orbiforme (Fr.) Ryvarden was originally described as 'Polyporus orbiformis' and identified by the strongly amyloid, irregular, tuberculate to blunted cuticle cells and moderately large basidiospores )Ryvarden 2000(. This is a. tropical species and was originally described from Guinea in Africa, and also known from Bonin Island in the Pacific and in the Neotropics )Ryvarden 2000(. Ganoderma orbiforme possess greater variability in morphology than other taxa in Ganoderma; rigid basidiocarp with a weakly to strongly laccate, partly laccate or dull pileus, variably brown context, ellipsoid to ovoid basidiospores with fine and short echinulae, and purplish brown pore surface at maturity (Wang et al. 2014(. Ganoderma cupreum, G. fornicatum, 
G. mastoporum, G. orbiforme, G. subtornatum and the species which originally described from China; $G$. densizonatum and $G$. limushanense are morphologically very similar to one another in basidiome texture, pilear cuticle structure, context and pore color and basidiospore characteristics. Hence, based on morphological and molecular data, it was concluded, that the above mentioned taxa are conspecific and G. orbiforme is the earliest valid name for use (Wang et al. 2014). Our collections from Hainan Province agree with the descriptions provided by Ryvarden (2000).
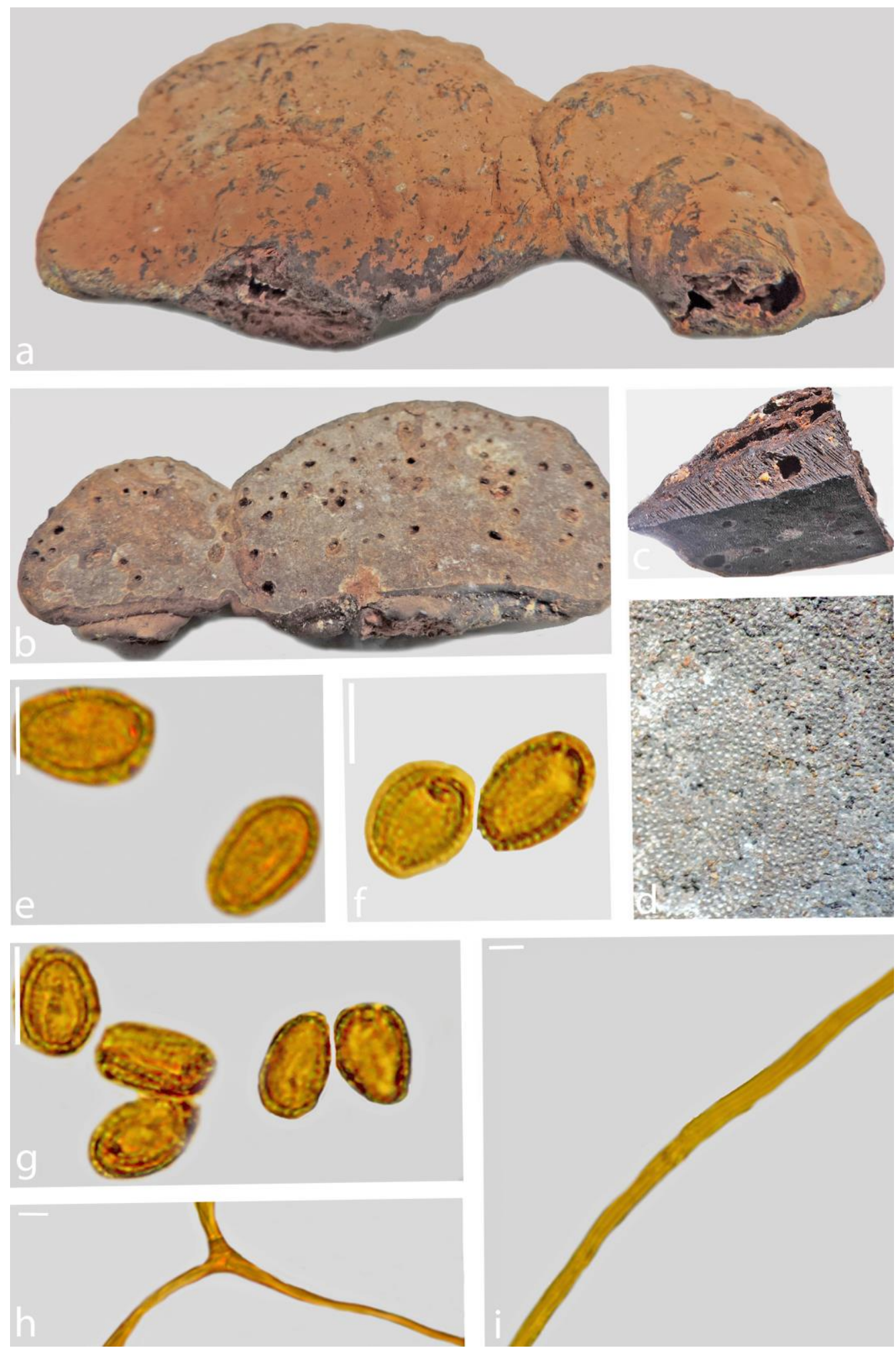

Figure 11 - Ganoderma orbiforme (GACP14081235) a Upper surface. b Lower surface. c section of the specimen. $d$ Pores in the lower surface $(4.5 \times)$. e-g Spores $(100 \times)$. h Binding hyphae (100x). i Skeletal hyphae $(100 \times)$. Scale bars: $\mathrm{e}-\mathrm{g}=10 \mu \mathrm{m}, \mathrm{h}-\mathrm{i}=5 \mu \mathrm{m}$. 


\section{Ganoderma cf. resinaceum}

Basidiome perennial, sessile, usually with a distinctly contracted base, laccate, corky. Pileus 7-12 $\times 4-10 \mathrm{~cm}$, up to $1.5 \mathrm{~cm}$ thick at the base, sub-orbicular, rotund, upper surface; reddish brown (8E8) to dark brown (8F8), concentrically sulcate zones with turberculate bumps and ridges and rivulose depressions, radially rugose, with irregularly ruptured crust overlying the pellis, margin; blunt to truncate, greyish orange (5B3), lower surface; light brown (7D5). Hymenophore up to 25 $\mathrm{mm}$ long, indistinctly stratose; pores initially greyish brown (7D3), bruising brown (8E8), pores circular or sub-circular, 5-6 per mm. Context up to $4 \mathrm{~mm}$ thick, duplex, dry; lower layer reddish brown (8E8), fibrous, composed of coarse loose fibrils; upper layer reddish brown (8E8), corky to woody. Basidiospores $(\mathrm{n}=25)(9.3-) 10.9-11.2-12.5(-12.8) \times(8.5-) 8.8-9.1-7.9(-8.3) \mu \mathrm{m}\left(Q_{m}=1.5\right.$, $Q=1.1-2.6$ with myxosporium). (6.7-)6.9-7.1-7.9(-8.1) × (3.5-)4.9-5.1-5.9(-6.3) $\mu \mathrm{m}\left(Q_{m}=1.5\right.$, $Q=0.9-2.9$, without myxosporium), ellipsoid, light orange (5A5), brownish orange (6C8) to light brown (5A5), with a brown eusporium bearing fine, short, and distinct echinulae, overlaid by a hyaline myxosporium. Pileipellis a hymeniderm, brownish orange (6C8), clavate like cells, dextrinoid. Context dimitic; skeletal hyphae $(\mathrm{n}=30)(3.1-) 4.5-5.4-6.5(-6.8) \mu \mathrm{m}$, thick-walled, nearly solid, sometimes branched, greyish brown (5B5); binding hyphae $(n=30)(2.5-) 3.6-4.1-$ 4.8(-5.4) $\mu \mathrm{m}$, thick-walled, branched, nearly solid, light brown (7D5) (Fig. 12).

Habitat - On a decaying tree trunk, accompanied in humus rich soil with over heavily rotted litter on the ground.

Specimens examined - CHINA, Hainan Province, Diaoluoshan National Nature Reserve, $18^{\circ}$ $68^{\prime} \mathrm{N}, 109^{\circ}$ 95' E, elv. $1058 \mathrm{~m}$, collection date unknown, collector X.L. Wu (GACP HNU02, GACP HNU58).

Notes - Ganoderma resinaceum was introduced by Boudier in 1889 from France (Patouillard 1889). This species is characterized by a pileus with varying colours, a fibrous spongy homogeneous context, larger basidiospores and an amyloid pileipellis (Ryvarden 2004). Ganoderma resinaceum has been described by Steyaert (1972), Ryvarden \& Gilbertson (1993) by emphasizing varying pileus color changes from shiny varnish laccate orange-yellow, brown, ochraceous-brown to reddish-brown pileus on young basidiocarps, that turn black or blackish when mature or ageing. This is because of different carotenoid pigments or/and secondary metabolites produced by $G$. resinaceum. However, this colour evolution and shiny varnish appearance of the pileus rarely applies to specimens of $G$. resinaceum growing in tropical climates (Ayissi \& Mossebo 2014). Steyaert (1980) grouped this species with Ganoderma parvulum as a complex due to the variations and inconsistencies of taxonomy in Ganoderma. Ganoderma resinaceum may be confused with $G$. boninense ( $=G$. orbiforme) (Torres-Torres et al. 2015). However, the particular combination of characters such as basidiomata color, fibrous spongy context without resinous bands, almost cylindrical to clavate cuticle cells, and ellipsoid basidiospores, with free and relatively thin pillars make it possible to identify this species as a species complex. Ganoderma resinaceum may be confused with those of $G$. pfeifferi which has a similar resinous layer on the upper crust in pileus, but this species has a dark brown to umber context and wider spores Ganoderma lucidum has a lighter context without a darker zone above the tubes and no resinous layer on the crust, thus making it much more glossy and shiny even in older specimens. The spores also appear more coarsely warted than those of G. resinaceum (Ryvarden \& Gilbertson 1993). Moncalvo (2000) differentiated $G$. resinaceum and $G$. weberianum from other related species. This specis may be confused with $G$. chalceum, which however has a black band in the context (Ryvarden 2004). Ganoderma resinaceum has been widely used in organisms very dissimilar to the species originally described by Boud and numerous new names have been designated for this common species based on macro morphological variations. This species was described for the first time in China by Zhao (1989) and later few Chinese authors recorded and described this species (Wu et al. 1999, Zhao \& Zhang 2000, Wu \& Dai 2005). Our study agrees both macroscopically and microscopically with the description from the holotype made by Ryvarden (2004) and TorresTorres et al. (2012). We identify our specimens as Ganoderma cf. resinaceum, since authentic type materials were not included in this study. This species is distributed Southern and Central Europe 
with a few isolated localities in southern Denmark, North Africa. Asia, North America and widespread in the Paleotropics (Ryvarden \& Gilbertson 1993).
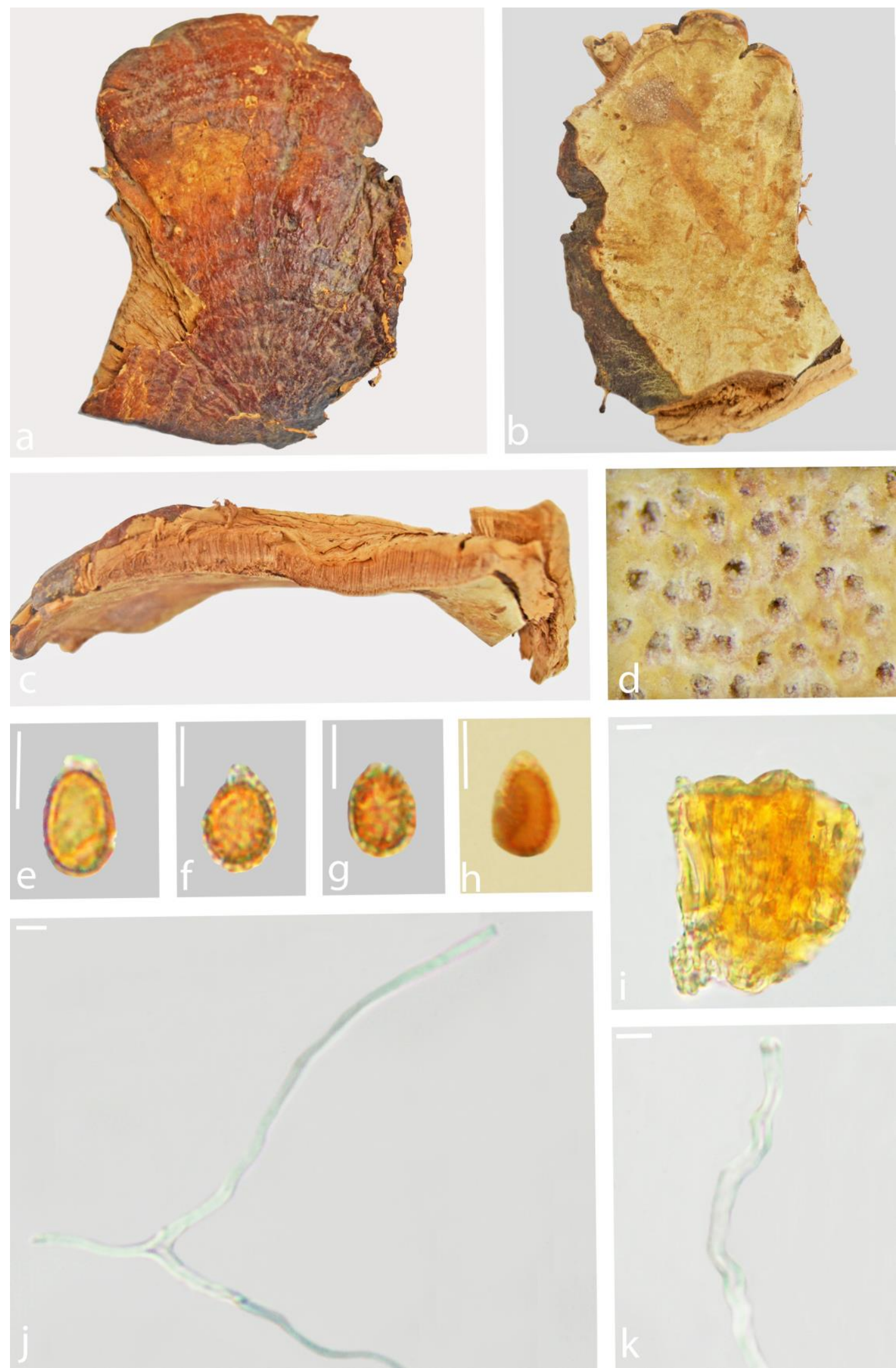

Figure 12 - Ganoderma cf. resinaceum (GACP HNU02) a Upper surface. b Lower surface. c Cut surface. d Pores in the lower surface $(5 \times)$. e-h Spores $(100 x)$. i Cuticle cells $(100 \times)$. j Binding hyphae $(100 \times)$. K Skeletal hyphae $(100 \times)$. Scale bars: $\mathrm{e}-\mathrm{h}=10 \mu \mathrm{m}, \mathrm{j}-1=5 \mu \mathrm{m}$. 
Ganoderma tropicum (Jungh.) Bres., Annls mycol. 8(6): 586 (1910)

$\equiv$ Polyporus tropicus Jungh. (1838)

= Fomes tropicus (Jungh.) Cooke, Grevillea 14(no. 69): 19 (1885)

= Scindalma tropicum (Jungh.) Kuntze, Revis. gen. pl. (Leipzig) 3(2): 519 (1898)

Basidiome annual, sessile (usually with a distinctly contracted base), strongly laccate, woody. Pileus $4-8 \times 2.5-6 \mathrm{~cm}$, up to $1 \mathrm{~cm}$ thick at the base, spathulate, plano convex; upper surface hard, several layers thick, yellowish brown (5F8), orange (6D8) to brown (7E8), crust overlies the pellis, containing fibrous pithy context, swollen differentiated zone at the point of attachment; margin soft, $1 \mathrm{~cm}$ thick, rounded, white (5A1); lower surface white (5A1) to orange (5B2). Hymenophore up to $4 \mathrm{~mm}$ long, indistinctly stratose, white (5A1) to orange (5B2), pores sub circular or isodiametric. Context up to $3 \mathrm{~cm}$ thick, dry, duplex; lower layer brown (7E8), fibrous, composed of coarse loose fibrils, soft; upper layer light brown (5A5), woody. Basidiospores $(\mathrm{n}=25)(10.8-) 11.2-$ 12.1-12.8(-13.1) $\times(8.3-) 9.6-10.1-10.8(11.1) \mu \mathrm{m}\left(Q_{m}=1.3, Q=0.9-1.5\right.$, with myxosporium). (7.9)8.8-9.1-10.2(-10.8) × (5.8-)6.4-7.3-7.8(-9.8) $\mu \mathrm{m}\left(Q_{m}=1.3, Q=1.1-1.7\right.$, without myxosporium), broadly ellipsoid, brownish orange (6C8) to light brown (5A5) eusporium bearing fine, short and distinct echinulae, overlaid by a hyaline myxosporium, bitunicate. Pileipellis a hymeniderm, greyish orange (5B5) to brown (6E8), composed of apically acanthus like branched cells, dextrinoid. Context trimitic; generative hyphae $(\mathrm{n}=30)(0.4-) 0.6-1.4-1.8(-2.6) \mu \mathrm{m}$ in width, thinwalled, hyaline skeletal hyphae $(\mathrm{n}=30)(2.8-) 3.1-3.4-3.8(-4.3) \mu \mathrm{m}$ in width, light brown (6D4), thick walled, sometimes branched; binding hyphae $(\mathrm{n}=30)(1.1-) 2.2-2.5-3.4(-3.8) \mu \mathrm{m}$ in width, light brown (6D4), thick walled, branched, intertwined the skeletal hyphae (Fig. 13).

Habitat - On a decaying wood log, accompanied in humus rich soil with over heavily rotted litter on the ground in forest, mossy temperate mixed coniferous forests, producing basidiomata from summer to late autumn.

Specimens examined - CHINA, Hainan Province, Wuzshishan Mountain, Coniferous rainforest, $18^{\circ} 53^{\prime} \mathrm{N}, 109^{\circ} 38^{\prime} \mathrm{E}$, elev. $1240 \mathrm{~m}, 15$ August 2014, collector T.C. Wen (GACP14081511, GACP14081518).

Notes - Ganoderma tropicum was introduced as Polyporus tropicus by Junghuhn (1838) from Java, Indonesia and later, Bresadola (1910) transferred this species to Ganoderma. Ganoderma tropicum is distributed from lowland tropical Asia and the subtropics (Steyaert 1972) and its taxonomy has been well-resolved with a strong bootstrap support (Wang et al. 2012, Yang \& Feng 2013). This species is characterized by broadly ellipsoid to ellipsoid basidiospores with thick echinulae and is considered as a member of the G. lucidum species complex (Zhou et al. 2015). Among the Chinese Ganoderma species, G. flexipes, G. multipileum, G. sichuanense, and G. tsugae are the most similar species to G. tropicum, since they share a reddish-brown pileal surface, similar basidiospores and cuticle cells, however G. tropicum differs from G. multipileum by having strongly echinulate basidiospores (Cao et al. 2012). Ganoderma tropicum was first reported from China by Tai (1979) and then few Chinese researchers have reported on this species (Zhao 1989, Bi et al. 1993, Zhao \& Zhang 2000). Our collections from Hainan Province agree well with the descriptions provided by the latter researchers. Wu et al. (1999), Li et al. (2010) and Dai et al. (2011) recorded this species from Hainan Province in their Polypore diversity checklists. Ganoderma tropicum causes white root and butt rot on several species of Acacia in forest plantations in China (Dai et al. 2007) and further it is one of the most aggressive pathogens that causes basal stem rot in oil palm (Turner 1981, Wong et al. 2012).

Ganoderma sinense J.D. Zhao, L.W. Hsu \& X.Q. Zhang, Acta Microbiol. Sin. 19(3): 272 (1979)

= Ganoderma formosanum T.T. Chang \& T. Chen in Trans. Or. Mycol. Soc. 82: 731 (1984).

Misapplications:

Ganoderma japonicum (Fr. Lloyd in Teng, Fungi of China; 447 (1963): Tai, Syll. Fung. Sin.: 469 (1979), Teng, Fungi of China: 326 (1996), non Polyporus japonicus Fr.,Epicrisis: 442 (1838) (Ganoderma japonicum (Fr.) Lloyd, Mycol. Writ. 3: Syn. Stip. Polyp.: 102(1912)). 
Ganoderma lucidum (Leyss.) P. Karst. var. japonicum (Fr.) Bres. in Teng in Sinensia 5:199 (1934). non Polyporus japonicus Fr., Epicrisis: 442 (1838).
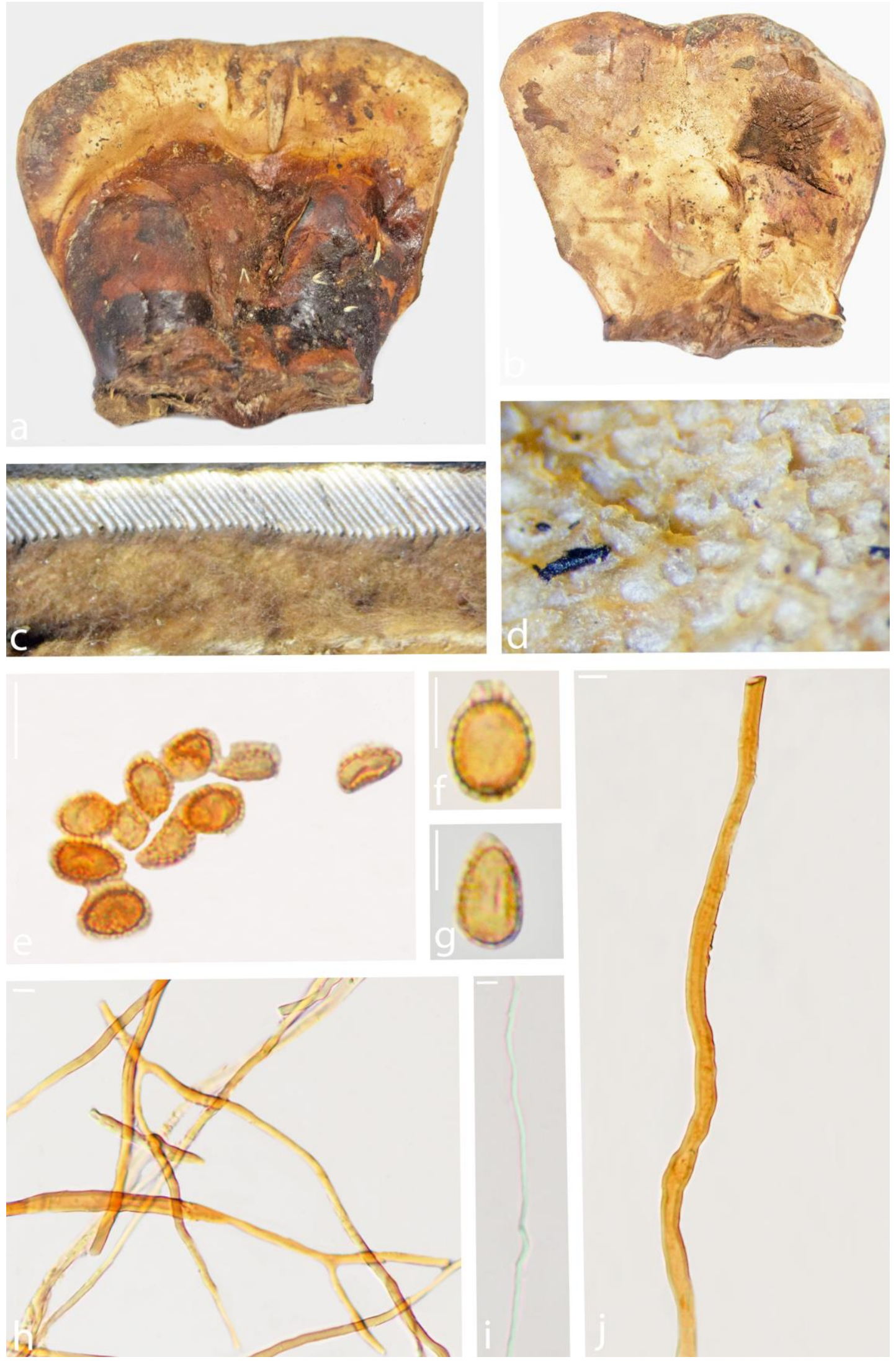

Figure 13 - Ganoderma tropicum (GACP14081518) a Upper surface. b Lower surface. c Cut surface. d Pores in the lower surface $(5 \times)$. e-g Spores $(100 x)$. h Binding hyphae $(100 \times)$. i Generative hyphae (100x). j Skeletal hyphae (100x). Scale bars: $e-g=10 \mu \mathrm{m}, \mathrm{h}-\mathrm{j}=5 \mu \mathrm{m}$. 
Basidiome annual, stipitate, strongly laccate, corky. Pileus $7-8 \times 5.0-5.5 \mathrm{~cm}$, up to $0.5 \mathrm{~cm}$ thick at the base, reniform, sub-dimidiate; upper surface dark brown (8F8), radially rugose, concentrically sulcate, with irregularly ruptured crust overlying the pellis; margin blunt, concolorous with the pileus; lower surface brown (7E8). Hymenophore up to $15 \mathrm{~mm}$ long, indistinctly stratose; pores initially dark brown (8F8), bruising brown (7E8), pores circular or subcircular, 4-5 per mm. Context up to $1 \mathrm{~cm}$ thick, duplex, dry; lower layer brown (7D8), fibrous, composed of coarse loose fibrils; upper layer dark brown (8F8), corky. Stipe eccentric, sub cylindrical, concolorous with the pileus, $8 \times 13 \mathrm{~cm}$. Basidiospores $(\mathrm{n}=25)(10.6-) 11.5-12.5-13.5(-$ $14.3) \times(7.1-) 7.7-8.3-8.9(-11.7) \mu \mathrm{m}\left(Q_{m}=1.5, Q=1.1-1.8\right.$ with myxosporium $)$. (6.8-)9.2-10.211.1(-11.7) $\times(5.4-) 6.1-6.8-7.7(-8.4) \mu \mathrm{m}\left(Q_{m}=1.5, Q=1.1-1.8\right.$, without myxosporium), ellipsoid, brownish orange (7C8) to reddish orange (7B8) with a brown eusporium bearing fine, short, and distinct echinulae, overlaid by a hyaline myxosporium. Pileipellis a hymeniderm, brownish orange (7C8), clavate like cells, dextrinoid. Context dimitic; generative hyphae $(\mathrm{n}=25)(0.5-1.6-3.3) \mu \mathrm{m}$ diam, colorless, thin-walled; skeletal hyphae $(\mathrm{n}=20)(3.3-4.5-5.2) \mu \mathrm{m}$ thick-walled, nearly solid, sometimes branched, orange (5A6); binding hyphae $(n=20)(3.4-4.6-5.5) \mu \mathrm{m}$, thick-walled, branched, nearly solid, light brown (5A5) (Fig. 14).

Habitat - On rotten wood, in dry dipterocarp forest and in upper mixed deciduous forest or growing up from soil. Producing basidiomata from summer to late autumn.

Specimens examined - CHINA, Hainan Province, Jiangfengling Mountain, Coniferous rainforest, $18^{\circ} 44^{\prime} \mathrm{N}, 108^{\circ} 51^{\prime} \mathrm{E}$, elev. $550 \mathrm{~m}$, collection date 12 August 2014, collector T.C. Wen (GACP14081236, GACP14081260).

Notes - Ganoderma sinense originated from China and is characterized by slightly longitudinally crested basidiospores and a uniformly brown to dark brown context. Our G. sinense collections from Hainan Province agree with that of the holotype as described by Wang \& Wu (2007), moreover with descirptons given by Bi et al. (1993), Zhao \& Zhang (2000), and Wu \& Dai (2005). This species was considered as G. lucidum or G. japonicum by Chinese authors (Teng 1934, 1939, 1963). Ganoderma sinense differs from G. lucidum in thin-fleshed basidiomata, with long, slender stipes, rarely branched skeletal hyphae with bovista type binding hyphae (Pegler \& Yao 1996). Ganoderma japonicum (= G. dimidiatum) has a yellow pileus when young, red brown or rusty brown at maturity and off-white context (Pegler \& Yao 1996), and is distinguished from the purplish black to black pileus and brown context in $G$. sinense. Ganoderma formosanum introduced by Chang \& Chen (1984) from Taiwan, is very similar with G. sinense in morphology. However, Zhao \& Zhang (2000) considered this species as a distinct species based on the duplex context and ovoid basidiospores and this conclusion was subsequently followed by Wu \& Dai (2005). However, Wang \& Wu (2007) studied both holotypes of $G$. formosanum and $G$. sinense carefully and concluded that both species similar in morphology. Furthermore, it was concluded that the latter species are synonyms and the earliest valid name to be used is $G$. sinense based on molecular and morphological data (Moncalvo et al. 1995a, Wang \& Wu 2007).

Ganoderma sinense is morphologically similar to G. orbiforme in having a purplish black to black laccate pileus, uniformly brown context or with whitish streaks or patches near the cuticle, a dorsally lateral or lateral stipe and a subtropical-tropical distribution. Ganoderma sinense however, can easily be distinguished from $G$. orbiforme by its erect stipe, cuticle composed of clavate cells, and ovoid basidiospores with few, long and thick echinulae (Wang et al. 2014). Pharmacopoeia of People's Republic of China 2000 edition (part one) has mentioned that the general term "Lingzhi" covers both "Chizhi (G. lucidum)" and "Zizhi (G. sinense)". However, with the aid of molecular data, G. lucidum and $G$. sinense were clearly distinguished as two different species (Zhou et al. 2008, Liao et al. 2015). Furthermore, based on chemotaxonomical data, Oxygenated lanostane-type triterpenes have been proven as suitable markers to differentiate G. lucidum and G. sinense (Fu et al. 2008). Among all Ganoderma species, only G. lucidum and G. sinense have been approved to produce health products (Zhou et al. 2016). 

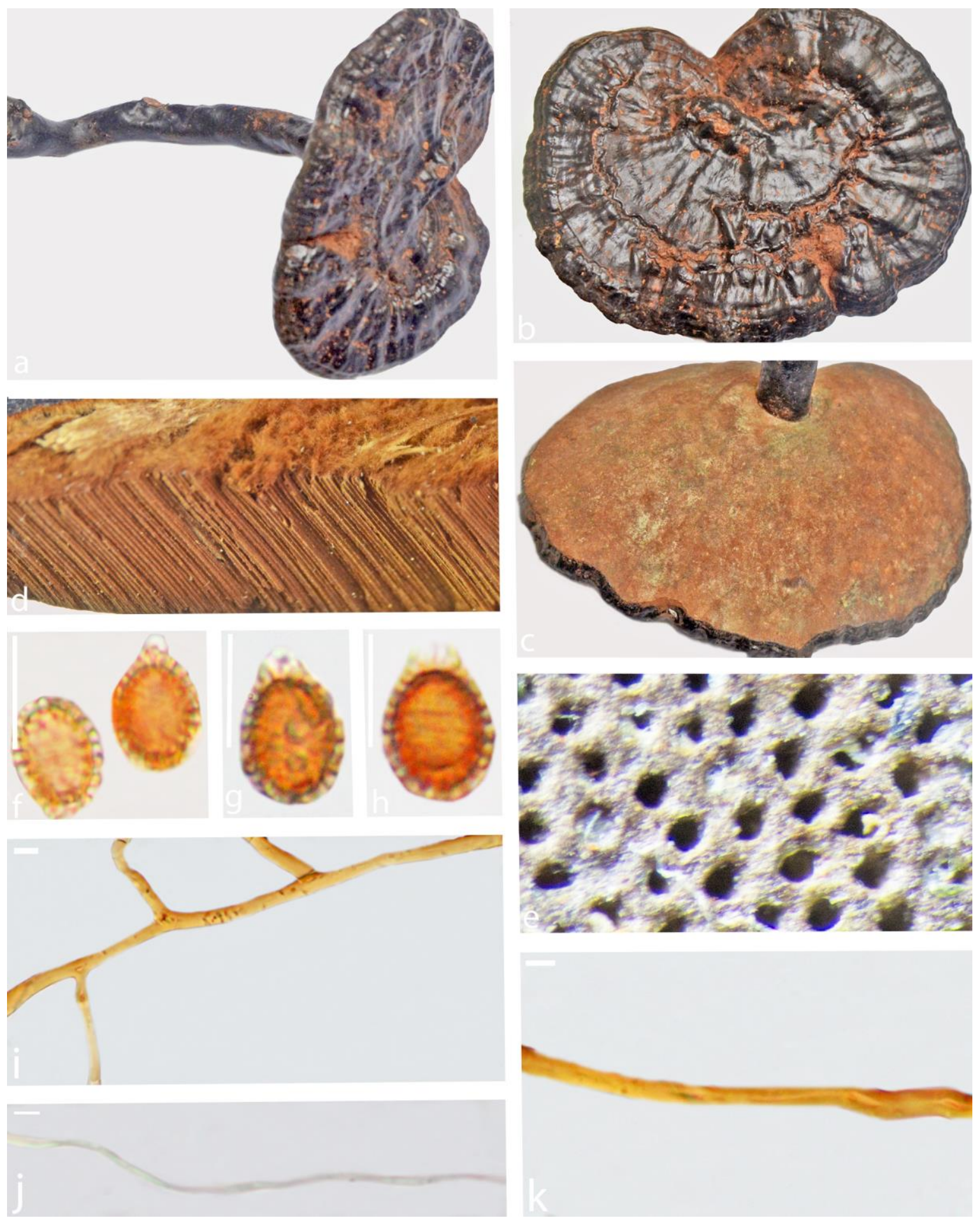

Figure 14 - Ganoderma sinense (GACP14081236) a, b Upper surface. c Lower surface. d Cut surface. e Pores in the lower surface (5x). $\mathrm{f}-\mathrm{h}$ Spores (100x). i Binding hyphae (40x). j generative hyphae (40x). k Skeletal hyphae (40x). Scale bars: $\mathrm{e}-\mathrm{h}=10 \mu \mathrm{m}, \mathrm{i}-\mathrm{j}=5 \mu \mathrm{m}$.

Ganoderma subresinosum (Murrill) C.J. Humphrey, Mycologia 30(3): 332 (1938)

$\equiv$ Fomes subresinosus Murrill 1908

= Polyporus mamelliporus Beeli, Bull. Soc. R. Bot. Belg. 62: 62 (1929)

= Trachyderma subresinosum (Murrill) Imazeki, Bull. Gov. Forest Exp. Stn Tokyo 57: 119 (1952)

= Magoderna subresinosum (Murrill) Steyaert, Persoonia 7(1): 112 (1972)

= Amauroderma subresinosum (Murrill) Corner, Beih. Nova Hedwigia 75: 93 (1983) 
Basidiome annual, sessile (with distinctly contracted base), weakly laccate, woody. Pileus 16-20 $\times 11-13 \mathrm{~cm}$, up to $4 \mathrm{~cm}$ thick at the base, sub-orbicular; upper surface dark brown (8F4), radially rugose, concentrically sulcate with irregularly ruptured crust overlying the context; margin blunt or wavy, yellow brown; lower surface brownish orange (6C4). Hymenophore up to $20 \mathrm{~mm}$ long, indistinctly stratose; pores initially greyish orange (5B3), bruising brownish orange (6C4), pores circular, 3-5 per mm. Context up to $2 \mathrm{~cm}$ thick, duplex, dry; lower layer, light orange (5A4), fibrous, composed of coarse loose fibrils; upper layer brownish orange (6C5), corky. Basidiospores $(\mathrm{n}=25)(13.3-) 13.9-15.3-16.5(-17.8) \times(8.0-) 9.2-10.2-11.1(-12.1) \mu \mathrm{m}\left(Q_{m}=1.5, Q=1.3-1.9\right.$ with myxosporium). (11.6-)12.2-13.5-14.8(-16.3) × (6.3-)7.3-8.4-9.5(-10.4) $\mu \mathrm{m}\left(Q_{m}=1.6, Q=1.3-2.2\right.$, without myxosporium), ellipsoid to ellongate, orange (6A6), pale orange (6A3) to greyish orange (5B4), with a brown eusporium bearing fine, short, and distinct echinulae, overlaid by a hyaline myxosporium. Pileipellis a hymeniderm, light orange (5A4), clavate like cells, dextrinoid. Context dimitic; generative hyphae not observed; skeletal hyphae $(n=25)(2.2-3.1-4.0) \mu m$, thick-walled, nearly solid, sometimes branched, orange white (5A2); binding hyphae $(n=20)(1.4-2.3-3.3) \mu \mathrm{m}$, thick-walled, branched, nearly solid, brownish orange (6C4) (Fig. 15).

Habitat - On a decaying wood log, accompanied in humus rich soil with over heavily rotted litter on the ground. Producing basidiomata from summer to late autumn.

Specimens examined - CHINA, Hainan Province, Wuzhishan Mountain, Coniferous rainforest, $18^{\circ} 53^{\prime} \mathrm{N}, 109^{\circ} 38^{\prime} \mathrm{E}$, elev. $1240 \mathrm{~m}$, collection date 16 August 2014, collector T.C. Wen (GACP14081663, GACP14081690).

Notes - Murrill (1908) introduced this species from the Philippines, as Fomes subresinosus, which characterized by smooth and hyaline basidiospores. Humphrey (1938) transferred this species to Ganoderma. Imazeki (1952) included this species in the genus Trachyderma as $T$. tsunodae Imazeki. Steyaert (1972) introduced the genus Magoderna, typified by M. subresinosus to accommodate species with dimidiate to pleuropodal basidiomata, anticlinal hyphae in the pilear surface and ovoid-ellipsoid to spherical basidiospores without a truncate apex. Furthermore, the genus has been considered as synonym of Amauroderma (A. subresinosum) (Corner 1983). However, this species is now recorded as $G$. subresinosum in Index Fungorum (www.indexfungorum/org/names/Names.asp). Recently some researchers suggested Magoderna (M. subresinosum) might be accepted at generic level based on strong morphological and molecular data (Gomes-Silva et al. 2015, Costa-Rezende et al. 2016, 2017). Ganoderma subresinosum was recorded from China by Teng (1963), Tai (1979), Teng (1996) as Fomes subresinosum and later reported by, Zhao (1989) and Zhao \& Zhang (2000) as A. subresinosum. The known distribution of this species extends from the Philippines to West Africa through Malaysia, Myanmar, India, Sri Lanka, Borneo Island and Eastern and Central Africa (Steyaert 1972).

Genus Amauroderma P. Karst., 1881, Rev. Mycol. (Toulouse) 3, p. 17.

= Amauroderma (Pat.) Torrend, Brotéria, sér. Bot. 18: 121 (1920)

= Ganoderma sect. Amauroderma Pat., Bull. Soc. mycol. Fr. 5(2, 3): 75 (1889)

= Lazulinospora Burds. \& M.J. Larsen, Mycologia 66(1): 97 (1974)

= Magoderna Steyaert, Persoonia 7(1): 111 (1972)

= Whitfordia Murrill, Bull. Torrey bot. Club 35: 407 (1908)

After Amauroderma was introduced, Torrend (1920) worked extensively on this genus in South America. He published an important work based mainly on spore shape (globose or oblong, never truncate) and the presence of a stipe (usually dull, like the pilear surface) and recorded 28 species of Amauroderma placed within three sections. Later, Amauroderma was carefully revised by Furtado (1981), who recognized 27 species. He defined Amauroderma by the globose to subglobose basidiospores, with double walls, stipitate basidiomes and a tropical distribution pattern. Ryvarden (2004) described 21 species of Amauroderma from the Neotropics, using the same genus circumscription. However, according to Index Fungorum (www.indexfungorum.org, accessed 21 August 2018), there are 135 binomials of this genus. Amauroderma is a widespread tropical genus that usually occurs on roots of living or dead trees or, is more rarely, wood 
inhabiting (Furtado 1981, Ryvarden 2004) and cause white rots. Macroscopically, Amauroderma shares similarities with Ganoderma, a similar basidiome shape of central or lateral stipe and laccate or dull surface. Ganoderma can be separated from Amauroderma by its distinctly truncate basidiospores, and most Ganoderma species grow on dead wood, while most Amauroderma species grow in the ground from buried roots/woods (Ryvarden 2004). Amauroderma species are regarded as economically valuable because of their important medicinal properties and pathogenicity (Dai et al. 2007, 2009, Jiao et al. 2013, Chan et al. 2013). In China, taxonomic research on Amauroderma began with Teng, who recorded ten species (Teng 1936, 1939, 1963). Later Zhao et al. (1979, 1983, 1984) and Zhao \& Zhang (1986, 1987, 2000) reported 20 species, nine of which were new. Here, we record two Amauroderma species found in Jiangfengling Mountain in Hainan Island, based on micro- and macro morphological characteristics together with molecular data.
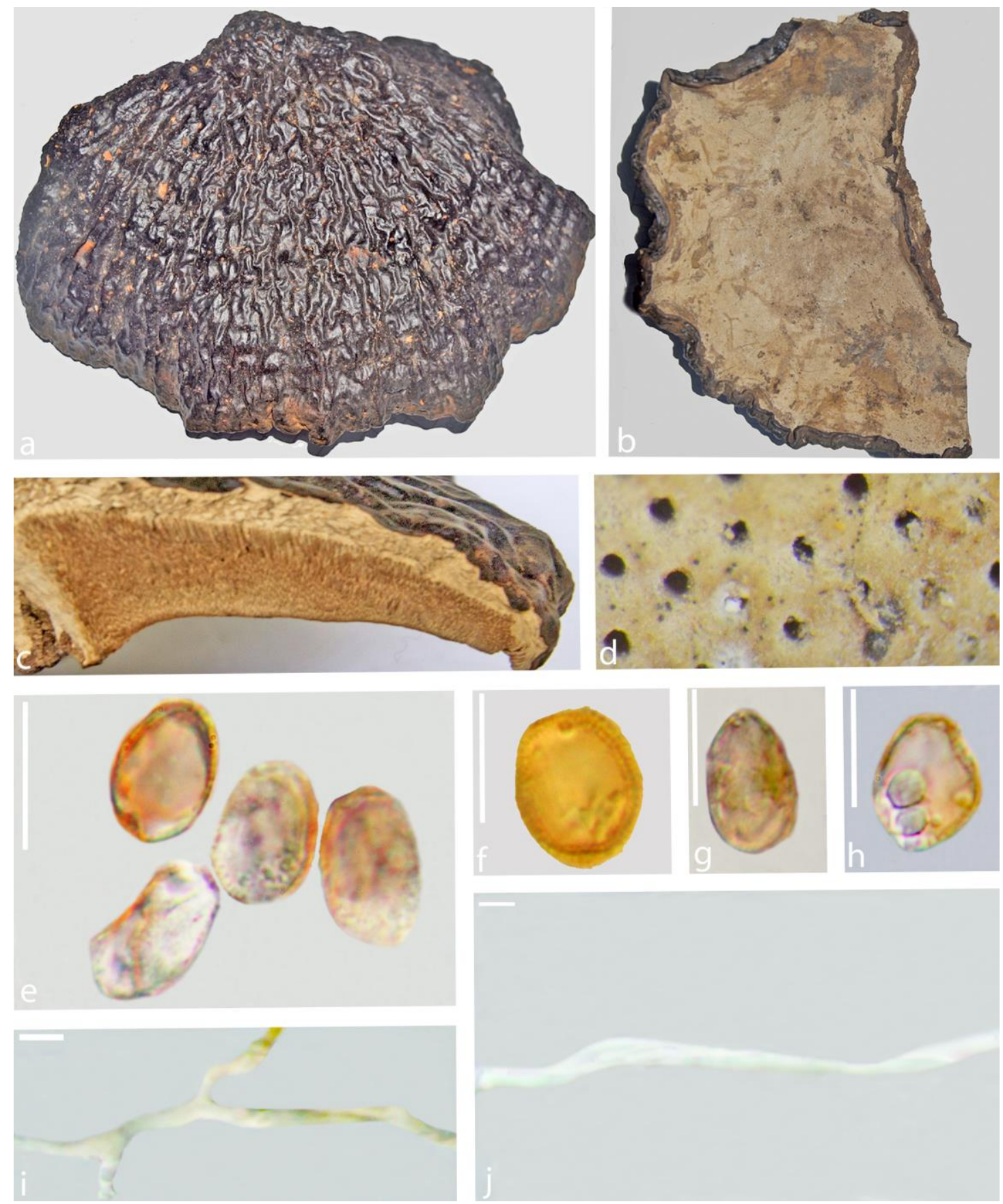

Figure 15 - Ganoderma subresinosum (GACP14081663) a Upper surface. b Lower surface. c Cut surface. d Pores in the lower surface (5x). e-h Spores (100x). i Binding hyphae (100x). j Skeletal hyphae $(100 \times)$. Scale bars: $\mathrm{e}-\mathrm{h}=10 \mu \mathrm{m}, \mathrm{i}-\mathrm{j}=5 \mu \mathrm{m}$. 
Amauroderma austrosinense J.D. Zhao \& L.W. Hsu, Acta Mycol. Sinica 3: 20. 1984.

Basidiome annual, stipitate, weakly laccate, corky. Pileus $3.5-5 \times 3.5-4.5 \mathrm{~cm}$, up to $0.5 \mathrm{~cm}$ thick at the base, orbicular, convex; upper surface soft, only few layers, containing fibrous context, alternating brownish orange (6C8) to light brown clay brown (6D4) concentrically zones, distinctly differentiated zone at the point of attachment; margin rounded, brownish orange (6C8), 1-2 mm thick; lower surface white (6A1). Hymenophore up to $2 \mathrm{~mm}$ long, orange white (6C2), pores circular or sub-circular or isodiametric. Context up to $2 \mathrm{~mm}$ thick at the base, dry, duplex; lower layer greyish brown (6D3), fibrous, soft, upper layer; orange white (6C2), composed of tightly interwoven, finer fibrils. Stipe stout cylindric, concolorous with the pileus, dorsally lateral, $6.5 \times 2$ cm. Basidiospores $(\mathrm{n}=50)(6.8-) 7.1-7.6-8.3(-9.6) \times(5.2-) 6.3-7.0-7.8(-9.5) \mu \mathrm{m}\left(Q_{m}=1.4, Q=0.9-\right.$ 1.5, with myxosporium). (3.9-)4.8-5.5-6.2(-6.3) × (3.6-)4.3-4.9-5.6(-6.7) $\mu \mathrm{m}\left(Q_{m}=1.2, Q=0.9-\right.$ 2.5 , without myxosporium), subglobose, brown (6E8) to dark brown 6F8), with a brown eusporium bearing fine, short, and distinct echinulae, overlaid by a hyaline myxosporium. Pileipellis a hymeniderm, brownish orange (6C8), composed of apically acanthus like branched cells. Context trimitic; generative hyphae $(\mathrm{n}=20)(2.6-) 1.9-2.5-3.1(-3.5) \mu \mathrm{m}$, hyaline, thin-walled with clamp connections, rarely seen; skeletal hyphae $(\mathrm{n}=40)(1.9-) 2.2-2.8-3.8(-4.0) \mu \mathrm{m}$, light brown (6D4), thick-walled, sometimes branched; binding hyphae $(n=40)(1.1-) 1.7-3.1-3.9(-4.3) \mu \mathrm{m}$, thickwalled, branched, light brown (6D4), intertwined the skeletal hyphae (Fig. 16).

Habitat - On rotten wood, in dry dipterocarp forest and in upper mixed deciduous forest or growing up from soil. Producing basidiomata from summer to late autumn.

Specimens examined - CHINA, Hainan Province, Jiangfengling Mountain, coniferous rainforest, $18^{\circ} 44^{\prime} \mathrm{N}, 108^{\circ} 51^{\prime}$ E, elev. $550 \mathrm{~m}$, collection date 10 August 2014, collector T.C. Wen (GACP14081030, GACP14081045).

Notes - Amauroderma austrosinense described by Zhao et al. (1984) from Hainan Province and is identified by its umbelliform basidiomes with distinct concentric rings, small pores and basidiospores. Even we were unable to obtain DNA, our collections agree well with the description of the holotype provided by Li \& Yuan (2015). Later, this species was described by many Chinese authors (Zhao 1989, Zhao \& Zhang 2000, Wu \& Dai 2005, Li \& Yuan 2015). Amauroderma camerarium (Berk.) J.S. Furtado is similar to A. austrosinense in its clay-colored, densely concentrically zoned, and radially furrowed pileus (Li \& Yuan 2015) and differs in its larger basidiospores $(12-15 \times 10-13 \mu \mathrm{m})$ (Ryvarden 2004). Amauroderma leucosporum is similar to A. austrosinense in having similar-sized subglobose to globose basidiospores, but it can be distinguished by it's finely to distinctly villous pileus and stipe (Corner 1983).

Amauroderma rugosum (Blume \& T. Nees) Torrend, Brotéria, sér. bot. 18(no. 2): 127 (1920)

= Amauroderma amoiense J.D. Zhao \& L.W. Hsu, Acta Mycol. Sinica 2: 164. (1983)

= Amauroderma wuzhishanense J.D. Zhao \& X.Q. Zhang, Acta Mycol. Sinica 6: 208. (1987)

(See Index Fungorum for other synonyms)

Basidiome annual, stipitate, weakly laccate, corky. Pileus $2.5-3.5 \times 2.0-2.5 \mathrm{~cm}$, up to $0.5 \mathrm{~cm}$ thick at the base, subreniform; upper surface brownish orange (6C4) to brown (6E8), radially rugose, concentrically sulcate with irregularly ruptured crust; margin blunt or wavy, concolorous with the pileus; lower surface greyish orange (5B5). Hymenophore up to $10 \mathrm{~mm}$ long, indistinctly stratose; pores initially brownish orange (5C4), bruising brown (6E8), pores circular, 3-5 per mm. Context up to $8 \mathrm{~mm}$ thick, duplex, dry; lower layer light brown (5D6), fibrous, composed of coarse loose fibrils, brown (6E8), corky. Stipe eccentric, sub cylindrical, concolorous with the pileus, $5 \times 7$ $\mathrm{cm},(0.5$ along stipe $) \mathrm{cm}$. Basidiospores $(\mathrm{n}=20)(11.8-) 12.9-13.4-13.9(-14.1) \times(10.2-) 10.8-11.2-$ $11.8(-12.1) \mu \mathrm{m}\left(Q_{m}=1.2, Q=1.1-1.4\right.$, with myxosporium). (11.9-)12.1-12.9-13.1(-13.5) $\times(9.6-$ )10.2-10.9-11.2(-11.8) $\mu \mathrm{m}\left(Q_{m}=1.2, Q=0.9-1.3\right.$, without myxosporium), subglobose, greyish orange (5B3), with a brown eusporium, overlaid by a hyaline myxosporium. Pileipellis a hymeniderm, brownish orange (5C4), clavate like cells, dextrinoid. Context dimitic; generative hyphae not observed; skeletal hyphae $(\mathrm{n}=25)(1.2-2.5-3.5) \mu \mathrm{m}$, thick-walled, nearly solid, 
sometimes branched, orange white (5A2); binding hyphae $(n=20)(0.6-1.7-2.6) \mu \mathrm{m}$, thick-walled, branched, nearly solid, orange white (5A2) (Fig. 17).
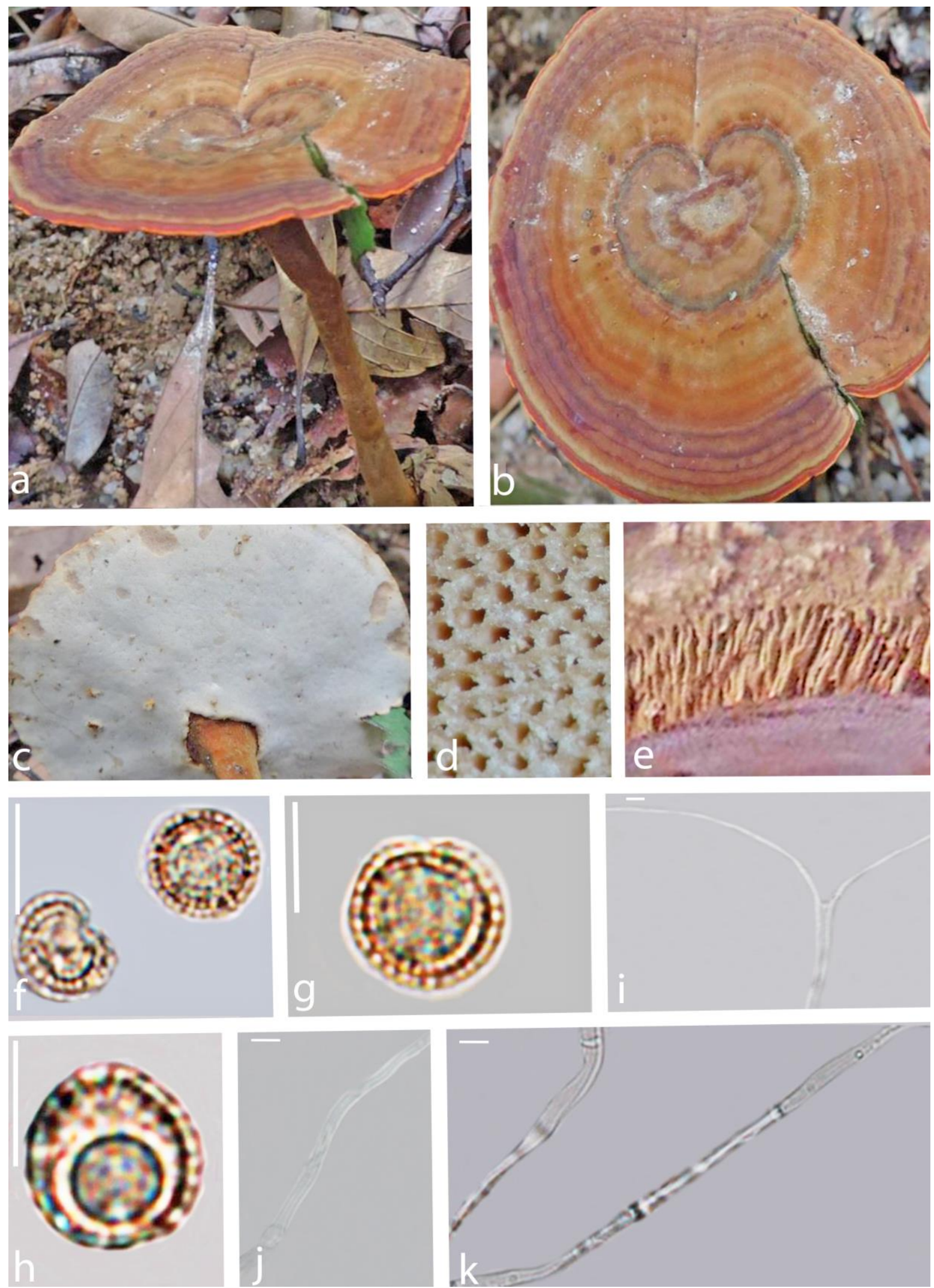

Figure 16 - Amauroderma austrosinense (GACP14081030) a In the wild. b Upper surface. c Lower surface. d Pores in the lower surface (4.5x). e Cut surface. $f-h$ Spores (100x). i Binding hyphae (40x). j Generative hyphae (40x). k Skeletal hyphae (40x). Scale bars: $\mathrm{f}-\mathrm{h}=10 \mu \mathrm{m}, \mathrm{i}-\mathrm{k}=5$ $\mu \mathrm{m}$. 

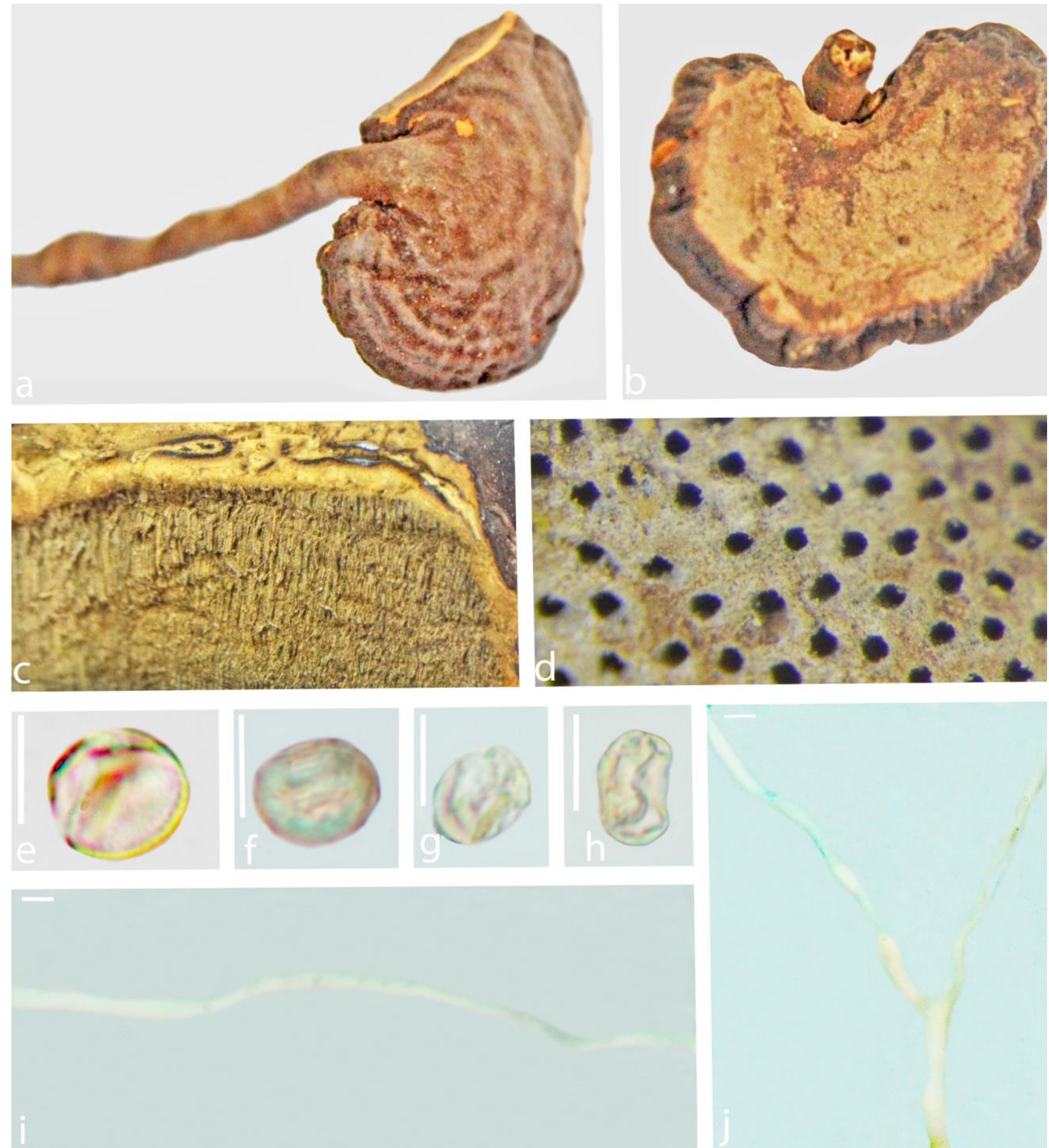

Figure 17 - Amauroderma rugosum (GACP14081210) a Upper surface. b Lower surface. c Cut surface. d Pores in the lower surface $(5 \times)$. e-h Spores $(100 \times)$. i Skeletal hyphae $(100 \times)$. j Binding hyphae $(100 \times)$. Scale bars: $\mathrm{e}-\mathrm{h}=10 \mu \mathrm{m}, \mathrm{i}-\mathrm{j}=5 \mu \mathrm{m}$.

Habitat - On rotten wood, in dry dipterocarp forest and in upper mixed deciduous forest or growing up from soil. Producing basidiomata from summer to late autumn.

Specimens examined - CHINA, Hainan Province, Jiangfengling Mountain, coniferous rainforest, $18^{\circ} 44^{\prime} \mathrm{N}, 108^{\circ} 51^{\prime} \mathrm{E}$, elev. $550 \mathrm{~m}$, elev. $1350 \mathrm{~m}$, collection date 9 August 2014, collector T.C. Wen (GACP14080910, GACP14080952, GACP14080929, GACP14080956).

Notes - Amauroderma rugosum is a soil-inhabiting saprobe (Baran De 1991) and Blume \& T. Nees described this species as Polyporus rugosus on the basis of specimens from Java in 1826 (Torrend 1920). Berkeley (1856) introduced a new species Porothelium rugosum from Brazil. Steyaert (1972) suggested Polyporus rugosus and Porothelium rugosum were similar species when comparing their morphological descriptions. Patouillard (1889) transferred Polyporus rugosus to 
Ganoderma (as G. rugosum). In 1894, Patouillard took up the name Porothelium rugosum Berk. and changed it as Ganoderma sprucei Pat. since he considered that there were already an epithet called "rugosum" in Ganoderma. Torrend (1920) transferred G. sprucei Pat. to Amauroderma (A. rugosum). Furtado (1968) synonymized P. rugosum Berk. as Amauroderma sprucei (Pat.) Torrend. Hence, it was a problem whether P. rugosum Berk. (= G. sprucei Pat.) and G. rugosum (BI. \& Nees) Pat. were similar species. Torrend therefore continued to use 'sprucei', the earliest epithet available in Amauroderma. Considering the combination of Porothelium rugosum in Foraminispora the epithet is available. However, Costa-Rezende et al. (2017) proposed Foraminispora, a new genus to accommodate Porothelium rugosum (= Amauroderma sprucei) with the aid of strong morphological and molecular data. According to Index Fungorum and MycoBank A. rugosum (Blume \& T. Nees) Torrend is now a legitimized species characterized by mesopodal and often excentric, or often pleuropodal pileus with subglobose basidiospores. This species was reported by Teng (1963) from China and later many Chinese researchers reported this species (Tai 1979, Zhao et al. 1981, Zhao 1989, Bi et al. 1993, Teng 1996, Zhao \& Zhang 2000). Ryvarden \& Johansen (1980) provided detailed description of this species and our collections agree well with that description and moreover, the descriptions provided by latter Chinese authors.

\section{Conclusions}

Species concepts within Ganoderma and Amauroderma have evolved from morphological species to phylogenetic and biological species. Macroscopic, microscopic, as well as molecular data confirmed one novel species together with records of 12 known species of Ganoderma and two known species of Amauroderma. This is the first comprehensive study of these two genera from Hainan Province, China. However, we need epitypes, reference collections, fresh collections and vouchered multigene nucleotide sequence data of more informative DNA markers to determine the taxonomy of Ganoderma and Amauroderma. The present study provides a snapshot useful for future taxonomic and phylogenetic studies, as well as for cultivation studies because of the high potential to use in biotechnology.

\section{Acknowledgements}

This work was financed by the Science and Technology Foundation of Guizhou Province (No. [2017]2511-1), and the Science Research Foundation of Guizhou University (No. 201309). Dr. Shaun Pennycook is thanked for nomenclatural advices. Kalani K. Hapuarachchi is grateful to Hansika Perera, Ishani Goonasekara and Monika Dayarathna for their valuable comments and suggestions.

\section{References}

Adaskaveg JE, Gilbertson RL. 1988 - Basidiospores, pilocystidia, and other basidiocarp characters in several species of the Ganoderma lucidum complex. Mycology 80, 493-507.

Adaskaveg JE, Blanchette RA, Gilbertson RL. 1991 - Decay of date palm wood by white-rot and brown-rot fungi. Canadian Journal of Botany 69, 615-629.

Atkinson GF. 1908 - On the identity of Polyporus applanatus of Europe and North America. Annales Mycologici 6, 179-191.

Ayissi BMK, Mossebo DC. 2014 - Some noteworthy taxonomic variations in the complex wooddecayer Ganoderma resinaceum (Basidiomycota) with reference to collections from tropical Africa. Kew Bulletin 69, 1-14.

Baby S, Johnson AJ, Govindan B. 2015 - Secondary metabolites from Ganoderma. Phytochemistry 114, 66-101.

Baran De A. 1991 - Distribution of Aphyllophorales in India II. Amauroderma rugosum, Amylosporus campbellii and Scytinopogon angulisporus. Acta Botanica Croatica 50, 55-58.

Berkeley MJ. 1856 - Decades of fungi. Decades LIX - LX. Rio Negro fungi. Hooker's Journal of Botany and Kew Garden Miscellany 8, 233-241. 
Bhosle S, Ranadive K, Bapat G, Garad S et al. 2010 - Taxonomy and diversity of Ganoderma from the Western parts of Maharashtra (India). Mycosphere 1, 249-262.

Bi ZS, Zheng G, Li TH. 1993 - The Macro fungus Flora of China's Guangdong Province, 119.

Bolaños-Rojas AC, Bononi VL, de Mello Gugliotta A. 2016 - New records of Ganoderma multiplicatum (Mont.) Pat.(Polyporales, Basidiomycota) from Colombia and its geographic distribution in South America. Check List, 12(4), 1948. http://dx.doi.org/10.15560/12.4.1948

Bresadola G. 1910 - Adnotanda in fungos aliquot exoticos regii Musei lugdunensis. Annals Mycologici 8(6), 585-589.

Bresadola G. 1912 - Fungi Congoenses. Annales Mycologici 9, 266-276.

Cao Y, Yuan HS. 2013 - Ganoderma mutabile sp. nov. from southwestern China based on morphological and molecular data. Mycological Progress 12, 121-126.

Cao Y, Wu SH, Dai YC. 2012 - Species clarification of the prize medicinal Ganoderma mushroom “Lingzhi', Fungal Diversity 56, 49-62.

Chan PM, Kanagasabapathy G, Tan YS, Sabaratnam V et al. 2013 - Amauroderma rugosum (Blume \& T. Nees) Torrend: Nutritional Composition and Antioxidant and Potential AntiInflammatory Properties. Evidence-Based Complementary and Alternative Medicine 2013. doi.org/10.1155/2013/304713.

Chang ST, Buswell JA. 1999 - Ganoderma lucidum (Curt. Fr.) P. Karst. (Aphyllophoromycetideae) - A mushrooming medicinal mushroom. International Journal of Medicinal Mushrooms 1, 139-146.

Chang TT, Chen T. 1984 - Ganoderma formosanum sp. nov. on Formosan sweet gum in Taiwan. Transactions of the British Mycological Society 82, 731-733.

Clemençon H. 2004 - Cytology and plectology of the Hymenomycetes. Bibliotheca Mycology 199, 486

Coetzee MP, Marincowitz S, Muthelo VG, Wingfield MJ. 2015 - Ganoderma species, including new taxa associated with root rot of the iconic Jacaranda mimosifolia in Pretoria, South Africa. IMA Fungus 6, 249-256. https://doi.org/10.5598/imafungus.2015.06.01.16

Coleman LC. 1927 - Structure of spore wall in Ganoderma. Botanical Gazette 83, 48-60.

Corner EJH. 1947 - Variation in the size and shape of spores, basidia and cystidia in Basidiomycetes. New Phytologist 46, 195-228.

Corner EJH. 1983 - Ad Polyporaceas I. Amauroderma and Ganoderma. Beihefte zur Nova Hedwigia 75, 11-82.

Correia de Lima N. Jr, Batista Gibertoni T, Malosso E. 2014 - Delimitation of some neotropical laccate Ganoderma (Ganodermataceae): molecular phylogeny and morphology. Revista de Biología Tropical 62, 1197-1208.

Costa-Rezende DH, Gugliotta AM, Goes-Neto A, Reck MA et al. 2016 - Amauroderma calcitum sp. nov. and notes on taxonomy and distribution of Amauroderma species (Ganodermataceae). Phytotaxa 244, 101-124.

Costa-Rezende DH, Robledo GL, Goes-Neto A, Reck MA et al. 2017 - Morphological reassessment and molecular phylogenetic analyses of Amauroderma s.lat. raised new perspectives in the generic classification of the Ganodermataceae family. Persoonia 39, 254 269.

Crous PW, Wingfield MJ, Le Roux JJ, Richardson DM et al. 2015 - Fungal Planet description sheets: 371-399. Persoonia: Molecular Phylogeny and Evolution of Fungi 35, 264.

Crous PW, Wingfield MJ, Burgess TI, Hardy GSJ, et al. 2017 - Fungal Planet description sheets: 558-624. Persoonia: Molecular Phylogeny and Evolution of Fungi 38, 240.

Dai YC, Wei YL, Wu XL. 2004 - Polypores from Hainan Province 1. Journal of Fungal Research 2, 53-57.

Dai YC, Cui BK, Yuan HS, Li BD. 2007 - Pathogenic wood-decaying fungi in China. Forest Pathology 37, 105-120.

Dai YC, Yang ZL, Cui BK, Yu CJ, Zhou LW. 2009 - Species diversity and utilization of medicinal mushrooms and fungi in China. International Journal of Medicinal Mushrooms 11, 287-302. 
Dai YC, Cui BK, Yuan HS, He SH et al. 2011 - Wood-inhabiting fungi in southern China. 4. Polypores from Hainan Province. Annales Botanici Fennici 48, 219-231.

Dai YC, Zhou LW, Hattori T, Cao Y et al. 2017 - Ganoderma lingzhi (Polyporales, Basidiomycota): the scientific binomial for the widely cultivated medicinal fungus Lingzhi. Mycological Progress 16(11-12), 1051-1055.

De Silva DD, Rapior S, Fons F, Bahkali AH et al. 2012a - Medicinal mushrooms in supportive cancer therapies: an approach to anti-cancer effects and putative mechanisms of action. Fungal Diversity 55, 1-35.

De Silva DD, Rapior S, Hyde KD, Bahkali AH. 2012b - Medicinal mushrooms in prevention and control of diabetes mellitus. Fungal Diversity 56, 1-29.

De Silva DD, Rapior S, Sudarman E, Stadler M et al. 2013 - Bioactive metabolites from macrofungi: ethnopharmacology, biological activities and chemistry. Fungal Diversity 62, 140 .

Donk MA. 1964 - A conspectus of families of Aphyllophorales. Persoonia 3, 199-324.

Ekandjo LK, Chimwamurombe PM. 2012 - Traditional Medicinal Uses and Natural Hosts of the Genus Ganoderma in North-Eastern Parts of Namibia. Journal of Pure and Applied Microbiology 6, 1139-1146.

Fu CM, Lu GH, Schmitz OJ, Li ZW et al. 2008 - Improved chromatographic fingerprints for facile differentiation of two Ganoderma spp. Biomedical Chromatography 23, 280-288.

Furtado JS. 1965 - Relation of microstructure of the taxonomy of the Ganodermataceae (Polyporaceae) with special reference to the structure of the cover of the pilear. Mycologia 57, 588-611.

Furtado JS. 1968 - Revisão do gênero Amauroderma (Polyporaceae). Estudos baseados nas microestruturas do basidiocarpo. PhD Thesis, Universidade de São Paulo, São Paulo (Brazil), 384.

Furtado JS. 1981 - Taxonomy of Amauroderma (Basidiomycetes, Polyporaceae). Memoirs of the New York Botanical Garden 34, 1-109.

Gilbertson RL, Ryvarden L. 1986 - North American Polypores 1. Fungi flora, Oslo.

Glen M, Bougher NL, Francis AA, Nigg SQ et al. 2009 - Ganoderma and Amauroderma species associated with root-rot disease of Acacia mangium plantation trees in Indonesia and Malaysia. Australasian Plant Pathology 38, 345-356.

Glen M, Yuskianti V, Puspitasari D, Francis A et al. 2014 - Identification of basidiomycete fungi in Indonesian hardwood plantations by DNA barcoding. Forest pathology 44, 496-508.

Global Administrative Areas. - http://www.gadm.org/download (accessed March 6, 2017).

Gomes-Silva AC, Lima-Júnior N, Malosso E, Ryvarden L et al. 2015 - Delimitation of taxa in Amauroderma (Ganodermataceae, Polyporales) based in morphology and molecular phylogeny of Brazilian specimens. Phytotaxa 227, 201-228.

Gottlieb AM, Saidman BO, Wright JE. 1995 - Characterization of six isoenzymatic systems in Argentine representatives of two groups of Ganoderma. Proceedings of Contributed Symposium, 59A, B $5^{\text {th }}$ International Mycological Congress (eds. PK Buchanan, RS Hseu and JM Moncalvo), 25-29.

Gottlieb AM, Saidman BO, Wright JE. 1998 - Isozymes of Ganoderma species from southern South America. Mycological Research 102, 415-426.

Gottlieb AM, Wright JE. 1999a - Taxonomy of Ganoderma from southern South America: subgenus Ganoderma. Mycological Research 103, 661-673.

Gottlieb AM, Wright JE. 1999b - Taxonomy of Ganoderma from southern South America: subgenus Elfvingia. Mycological Research 103, 1289-1298.

Guglielmo F, Gonthier P, Garbelotto M, Nicolott G. 2008 - A PCR-based method for the identification of important wood rotting fungal taxa within Ganoderma, Inonotus s.l. and Phellinus s.1. FEMS Microbiology Letters 282, 228-237. https://doi.org/10.1111/j.15746968.2008.01132.x 
Hall TA. 1999 - BioEdit: a user-friendly biological sequence alignment editor and analysis program for Windows 95/98/NT. In: Nucleic Acids Symposium Series 41, 95-98.

Hapuarachchi KK, Wen TC, Deng CY, Kang JC et al. 2015 - Mycosphere Essays 1: Taxonomic confusion in the Ganoderma lucidum species complex. Mycosphere 6, 542-559. Doi: 10.5943/mycosphere/6/5/4

Hapuarachchi KK, Wen TC, Jeewon R, Wu XL et al. 2016a - Mycosphere Essays 7: Ganoderma lucidum - are the beneficial anti-cancer properties substantiated? Mycosphere 7, 305-332. Doi: 10.5943/ Mycosphere/7/3/6.

Hapuarachchi KK, Wen TC, Jeewon R, Wu XL et al. 2016b - Mycosphere Essays 15: Ganoderma lucidum - are the beneficial medical properties substantiated? Mycosphere 7, 687-715. Doi: 10.5943/mycosphere/7/6/1.

Hapuarachchi KK, Cheng CR, Wen TC, Jeewon R et al. 2017 - Mycosphere Essays 20: Therapeutic potential of Ganoderma species: Insights into its use as traditional medicine. Mycosphere 8, 1653-1694, Doi: 10.5943/mycosphere/8/10/5

Hepting GH. 1971 - Diseases of forest and shade trees of the United States. US Department of Agriculture, Agricultural Handbook 386, 1-658.

Hong KK, Geon SS, Hong GK. 2001 - Comparison of characteristics of Ganoderma lucidum according to geographical origins: Consideration of morphological characteristics. Micobiology 29, 80-84.

Hong SG, Jeong W, Jung HS. 2002 - Amplification of mitochondrial small subunit ribosomal DNA of polypores and its potential for phylogenetic analysis. Mycologia 94, 823-833.

Hong SG, Jung HS. 2004 - Phylogenetic analysis of Ganoderma based on nearly complete mitochondrial small-subunit ribosomal DNA sequences. Mycologia 96, 742-755.

Hseu RS, Wang HH, Wang HF, Moncalvo JM. 1996 - Differentiation and grouping of isolates of the Ganoderma lucidum complex by random amplified polymorphic DNA-PCR compared. Applied environmental microbiology 62, 1354-1363.

Humphrey CJ. 1938 - Notes on some Basidiomycetes from the Orient. Mycologia 30, 327-335.

Humphrey CJ, Leus S. 1931 - A partial revision of the Ganoderma appalanatum group, with particular reference to its oriental variants. Philippine Journal of Science 45, 483-589.

Imazeki R. 1952 - A contribution to the fungus flora of Dutch New Guinea. Bulletin of the Government Forest Experiment Station, Tokyo 57, 87-128.

Index Fungorum - http://www.indexfungorum.org (accessed 21 August 2018).

Jargalmaa S, Eimes JA, Park MS, Park JY et al. 2017 - Taxonomic evaluation of selected Ganoderma species and database sequence validation. Peer J, 5, p.e3596.

Jayasiri SC, Hyde KD, Ariyawansa HA, Bhat J et al. 2015 - The Faces of Fungi database: fungal names linked with morphology, phylogeny and human impacts. Fungal Diversity 74, 3-18. https://doi.org/10.1007/ s13225-015-0351-8

Jiao C, Xie YZ, Yang X, Li H et al. 2013 - Anticancer Activity of Amauroderma rude. PLoS ONE 8(6): e66504. doi:10.1371/journal.pone.0066504.

Junghuhn FW. 1838 - Praemissae in floram cryptogamicam Java insulae (Batavia). In Verh. Batav. Genootsch 17, 1-86 (preprint).

Kaliyaperumal M, Kalaichelvan PT. 2008 - Ganoderma australe from southern India. Microbiological Research 163, 286-292.

Karsten PA. 1881 - Enumeralio boletinearum et polypore arum fennicarum, systemate novo dispositarum. Revue Mycologie 3, 16-19.

Karsten PA. 1889 - Kritisk översikt af Finlands basidsvampar (Basidiomycetes et Hymenomycetes): 470, Helsingfors.

Katoh K, Standley DM. 2013 - MAFFT multiple sequence alignment software version 7: improvements in performance and usability. Molecular biology and Evolution 30, 772-780. https://doi.org/10.1093/molbev/mst010.

Kinge TR, Mih AM. 2011 - Ganoderma ryvardense sp. nov. associated with basal stem rot (BSR) disease of oil palm in Cameroon. Mycosphere 2, 179-188. 
Kirk PM, Cannon PF, Minter DW, Stalpers JA. 2008 - Dictionary of the Fungi. CAB International, Wallingford.

Kornerup A, Wanscher JH. 1978 - Eyre Methuen, London, Methuen handbook of color.

Lai T, Gao Y, Zhou SF. 2004 - Global marketing of medicinal Lingzhi mushroom Ganoderma lucidum (W.Curt:Fr.) Lloyd (Aphyllophoromycetideae) products and safety concerns. International Journal of Medicinal Mushrooms 6, 189-194.

Leonard AC. 1998 - Two Ganoderma species compared. Mycologist 2, 65-68.

Li MJ, Yuan HS. 2015 - Type studies on Amauroderma species described by J.D. Zhao et al. and the phylogeny of species in China. Mycotaxon 130: 79-89. http://dx.doi.org/10.5248/130.79.

Li HJ, He SH, Cui BK. 2010 - Polypores from Bawangling Nature Reserve, Hainan Province. Mycosystema 29, 828-833.

Li TH, Hu HP, Deng WQ, Wu SH et al. 2015 - Ganoderma leucocontextum, a new member of the G. lucidum complex from southwestern China. Mycoscience 56, 81-85.

Liao B, Chen X, Han J, Dan Y et al. 2015 - Identification of commercial Ganoderma (Lingzhi) species by ITS2 sequences. Chinese medicine 10, 22.

Matheny PB, Wang Z, Binder M, Curtis JM et al. 2007 - Contributions of rpb2 and tef1 to the phylogeny of mushrooms and allies (Basidiomycota, Fungi). Molecular Phylogenetics and Evolution 43, 430-451. https://doi.org/10.1016/j.ympev.2006.08.024.

Miller RE, Blair PD. 2009 - Input-output analysis: foundations and extensions. Cambridge University Press. https://doi.org/10.1017/CBO9780511626982

Miller RNG, Holderness M, Bridge PD, Chung GF et al. 1999 - Genetic diversity of Ganoderma in oil palm plantings. Plant Pathology 48, 595-603.

Ming D, Chilton J, Fogarty F, Towers GHN. 2002 - Chemical constituents of Ganoderma applanatum of British Columbia forests. Fitoterapia 73, 147-152.

Mohanty PS, Harsh NSK, Pandey A. 2011 - First report of Ganoderma resinaceum and G. weberianum from north India based on ITS sequence analysis and micromorphology. Mycosphere 2, 469-474.

Moncalvo JM. 2000 - Systematics of Ganoderma. In Ganoderma Diseases of Perennial Crops (ed. J. Flood, P. D. Bridge and M. Holderness), 23-45. CABI Bioscience, Egham, UK.

Moncalvo JM, Buchanan PK. 2008 - Molecular evidence for long distance dispersal across the Southern Hemisphere in the Ganoderma applanatum-australe species complex (Basidiomycota). Mycological research 112, 425-436.

Moncalvo JM, Ryvarden L. 1997 - A nomenclatural study of the Ganodermataceae Donk. Fungi flora. 10, 1-114.

Moncalvo JM, Wang HF, Hseu RS. 1995a - Gene phylogeny of the Ganoderma lucidum complex based on ribosomal DNA sequences. Comparison with traditional taxonomic characters. Mycological Research 99, 1489-1499.

Moncalvo JM, Wang HF, Wang HH, Hseu RS. 1995b - The use of ribosomal DNA sequence data for species identification and phylogeny in the Ganodermataceae. In Ganoderma: Systematics, Phytopathology and Pharmacology. Proceedings of Contributed Symposium 59AB. 5th International Mycological Conference (ed. PK Buchanan, RS Hseu and JM. Moncalvo), National Taiwan University, Taipei, Vancouver, 31-44.

Moncalvo JM, Wang HF, Wang HH, Hseu RS. 1995c - The use of ribosomal DNA sequence data for species identification and phylogeny in the Ganodermataceae. Proceedings of Contributed Symposium, 59A, B 5th International Mycological Congress (eds. PK Buchanan, RS Hseu and JM Moncalvo). 31-44.

Monkai JM, Hyde KD, Xu JC, Mortimer PE. 2016 - Diversity and Ecology of soil fungal communities in rubber plantation. Fungal Biology Reviews 31, 1-11.

Mueller GM, Shcmit JP, Leacock PR, Buyck B et al. 2007 - Global diversity and distribution of macro fungi. Biodiversity and Conservation 16, 37-48.

Murrill WA. 1902 - The Polyporaceae of North America I. The genus Ganoderma. Bulletin of the Torrey Botanical Club 29, 599-608. 
Murrill WA. 1903 - The Polyporaceae of North America. IV. The genus Elfvingia. Bulletin of the Torrey Botanical Club 30, 296-301.

Murrill WA. 1905 - Tomophagus for Dendrophagus. Torreya, 5, 197.

Murrill WA. 1908 - Polyporaceae, Part 2. North American Flora 9, 73-131.

Nilsson RH, Tedersoo L, Abarenkov K. 2012 - Five simple guidelines for establishing basic authenticity and reliability of newly generated fungal ITS sequences. MycoKeys 4, 37-63. https://doi.org/10.3897/mycokeys.4.3606.

Nylander JAA. 2004 - MrModeltest v2.2. Program distributed by the author: 2. Evolutionary Biology Centre, Uppsala University 1-2.

Park DS, Sung JM, Kim YS, Yoo YB et al. 1994 - Analysis of Interspecific Allozyme varition within genus Ganoderma by polyacrylamide Gel Isoeletric Focusing RDA. Journal of Agriculture 36, 212-221.

Park YJ, Kwon OC, Son ES, Yoon DE et al. 2012 - Genetic diversity analysis of Ganoderma species and development of a specific marker for identification of medicinal mushroom Ganoderma lucidum. African Journal of Microbiology Research 25, 5417-5425. https://doi.org/10.5897/AJMR12.846

Parmasto E. 1986 - Preliminary list of Vietnamese Aphyllophorales and Polyporaceae s. str. Tanlin. Scripta Mycologica 14, 88 (In Vietnamese, English and Russian; English Introduction, 10-12).

Patouillard NT. 1887 - Notes sur quelques champignons de l'Herbier du Mus6um d'Histoire naturelle de Paris. Journal of Botany 1, 169-171.

Patouillard NT. 1889 - Le genre Ganoderma. Bulletin trimestriel de la Société mycologique de France 5, 64-80.

Patouillard N. 1907 - Basidiomycètes nouveaux du Brésil recueillis par F. Noack. Annales Mycologici 5, 364-366.

Pegler DN, Yao YJ. 1996 - Oriental species of Ganoderma section Ganoderma. In Wasser SP (ed). Botany and mycology for the next millennium: collection of scientific articles devoted to the 70th Anniversary of Academician Sytnik KM. Kyiv: Kholodny NG Institute of Botany, National Academy of Sciences of Ukraine, 336-347.

Pegler DN, Young TWK. 1973 - Basidiospores form in the British species of Ganoderma Karst. Kew Bulletin 28, 351-369.

Peng XR, Liu JQ, Wang CF, Li XY et al. 2014 - Hepatoprotective effects of triterpenoids from Ganoderma cochlear. Journal of Natural Products 77, 737-743.

Pilotti CA, Sanderson FR, Aitken EAB. 2003 - Genetic structure of a population of Ganoderma boninense on oil palm. Plant Pathology 52, 455-63.

Pilotti CA, Sanderson FR, Aitken AB, Armstrong W. 2004 - Morphological variation and host range of two Ganoderma species from Papua New Guinea. Mycopathologia 158, 251-265.

Rambaut A. 2012 - FigTree version 1.4.0. (http://tree.bio.ed.ac.uk/software/figtree/).

Rambaut A, Suchard MA, Xie D, Drummond AJ. 2013 - Tracer version 1.6. University of Edinburgh. [Online]. [Accessed on 19.11.2016] available at http://tree.bio.ed.ac.uk/software/tracer.

Richter C, Wittstein K, Kirk MP, Stadler M. 2015 - An assessment of the taxonomy and chemotaxonomy of Ganoderma. Fungal Diversity 71. doi: 10.1007/s13225-014-0313-6 71.

Ryvarden L. 1983 - Type studies in the Polyporaceae 14. Species described by N. Patouillard, either alone or with other mycologists. Occasional Papers of the Farlow Herbarium of Cryptogamic Botany, 1-39.

Ryvarden L. 1985 - Type studies in the Polyporaceae 17 Species described by W. A. Murrill. Mycotaxon 23, 169-198.

Ryvarden L. 1995 - Can we trust morphology in Ganoderma? In: Buchanan PK, Hseu RS, Moncalvo JM, editors. Ganoderma: Systematics, Phytopathology and Pharmacology. Proceedings of Contributed Symposium 59A, B, 5th International Mycological Congress, Vancouver, August 14-21, 1994. Taipei: National Taiwan University. 19-24. 
Ryvarden L. 2000 - Studies in Neotropical polypores 2: a preliminary key to Neotropical species of Ganoderma with a laccate pileus. Mycologia 92, 180-191.

Ryvarden L. 2004 - Neotropical polypores Part 1. Synopsis Fungorum. 19, 1-229.

Ryvarden L, Gilbertson RL. 1993 - European Polypores. 1. Abortiporus - Lindtneria. Oslo: Fungi flora, 387.

Ryvarden L, Johansen I. 1980 - A preliminary polypores flora of East Africa. Fungi flora, Oslo, 1636.

Saccardo PA. 1888 - Sylloge Hymenomycetum, Vol. II. Polyporeae, Hydneae, Thelephoreae, Clavarieae, Tremellineae. Sylloge Fungorum 6, 156.

Seo GS, Kirk PM. 2000 - Systematics of Ganoderma. In Ganoderma Diseases of Perennial Crops (ed. J. Flood, P. D. Bridge and M. Holderness), 23-45. CABI Bioscience, Egham, UK.

Singh SK, Doshi A, Pancholy A, Pathak R. 2013 - Biodiversity in wood-decay macro-fungi associated with declining arid zone trees of India as revealed by nuclear rDNA analysis. European Journal of Plant Pathology, 1-10.

Smith BJ, Sivasithamparam K. 2000 - Internal transcribed spacer ribosomal DNA sequence of five species of Ganoderma from Australia. Mycological Research 104, 943-951.

Smith BJ, Sivasithamparam K. 2003 - Morphological studies of Ganoderma (Ganodermataceae) from the Australian and Pacific regions. Australasian Systematic Botany 16, 487-503.

Song J, Xing JH, Decock C, HE XL et al. 2016 - Molecular phylogeny and morphology reveal a new species of Amauroderma (Basidiomycota) from China. Phytotaxa 260, 47-56. Doi: http://dx.doi.org/10.11646/phytotaxa.260.1.5.

Stalpers JA. 1978 - Identification of wood-inhabiting fungi in pure culture. Studies in Mycology $16,1-248$.

Stamatakis A. 2014 - RAxML version 8: a tool for phylogenetic analysis and post-analysis of large phylogenies. Bioinformatics 30, 1312-1313. https://doi.org/10.1093/bioinformatics/btu0 33.

Steyaert RL. 1972 - Species of Ganoderma and related genera mainly of the Bogor and Leiden Herbaria. Persoonia 7, 55-118.

Steyaert RL. 1975a - The concept and circumscription of Ganoderma tornatum. Transactions of the British Mycological Society 65, 451-467.

Steyaert RL. 1975b - Ganoderma applanatum. CMI Descriptions of Pathogenic Fungi and Bacteria. 443, 1-2.

Steyaert RL. 1980 - Study of some Ganoderma species. Bulletin Jardin Botanique Nationale de Belgique 50, 135-186.

Su CL, Tang CH, Zhang JS, Chen MJ et al. 2007 - The phylogenetic relationship of cultivated isolates of Ganoderma in China inferred from nuclear ribosomal DNA ITS sequences. Acta Microbiologica Sinica 47, 11-16.

Sun SJ, Gao W, Lin SQ, Zhu J et al. 2006 - Analysis of genetic diversity in Ganoderma populations with a novel molecular marker SRAP. Applied Microbiology Biotechnology 72, 537-543.

Szedlay G. 2002 - is the widely used medicinal fungus the Ganoderma lucidum (fr.) karst. sensu stricto? Acta Microbiologica et Immunologica Hungarica 49, 235-243.

Tai FL. 1979 - Sylloge Fungorum Sinicorum. Beijing: Science Press, 1527 (in Chinese).

Teng SC.1934 - Notes on Polyporaceae from China. Sinensia 5, 198-200.

Teng SC. 1936 - Additional fungi from China III. Sinensia. 7, 529-569.

Teng SC. 1939 - A contribution to our knowledge of the higher fungi of China. National Institute of Zoology \& Botany, Academia Sinica.

Teng SC. 1963 - Fungi of China. Beijing: Science Press, 808. (in Chinese).

Teng SC. 1996 - Fungi of China. Mycotaxon Ithaca 1-586.

Terho M, Hantula J, Hallaksela AM. 2007 - Occurrence and decay patterns of common wooddecay fungi in hazardous trees felled in the Helsinki City. Forest Pathology 37, 420-432. doi: 10.1111/j.1439-0329.2007.00518.x 
Thawthong A, Hapuarachchi KK, Wen TC, Raspé O et al. 2017 - Ganoderma sichuanense (Ganodermataceae, Polyporales) new to Thailand. MycoKeys 22, 27-43. https://doi.org/10.3897/ mycokeys.22.13083

Torrend C. 1920 - Les polyporacées du Bresil. Broteria, série botânica 18, 121-142.

Torres-Torres MG, Guzmán-Dávalos L, Guggliota AM. 2012 - Ganoderma in Brazil: known species and new records. Mycotaxon 121, 93-132.

Torres-Torres MG, Ryvarden L, Guzmán-Dávalos L. 2015 - Ganoderma subgénero Ganoderma en México. Revista Mexicana de Micología 41, 27-45.

Turner PD. 1981 - Oil Palm Diseases and Disorders. Oxford University Press, 88-110.

Wagner R, Mitchell DA, Sassaki GL, Amazonas MALA et al. 2003 - Current techniques for the cultivation of Ganoderma lucidum for the production of biomass, ganoderic acid and polysaccharides. Food Technology and Biotechnology 41, 371-382.

Wang DM, Wu SH. 2007 - Two species of Ganoderma new to Taiwan. Mycotaxon 102, 373-378.

Wang DM, Wu SH, Su CH, Peng JT et al. 2009 - Ganoderma multipileum, the correct name for 'G. lucidum' in tropical Asia. Botanical Studies 50, 451-458.

Wang DM, Wu SH. 2010 - Ganoderma hoehnelianum has priority over G. shangsiense, and G. williamsianum over G. meijiangense. Mycotaxon 113, 343-349.

Wang DM, Zhang XQ, Yao YJ. 2005 - Type studies of some Ganoderma species from China. Mycotaxon 93, 61-70.

Wang DM, Wu SH, Yao YJ. 2014 - Clarification of the concept of Ganoderma orbiforme with high morphological plasticity. PLoS ONE 9: e98733.

Wang F, Dong ZJ, Liu JK. 2007 - Benzopyran-4-one derivatives from the fungus Ganoderma applanatum. Zeitschrift für Naturforschung 62b, 1329-1332.

Wang XC, Xi RJ, Li Y, Wang DM et al. 2012 - The Species Identity of the Widely Cultivated Ganoderma, 'G. lucidum' (Ling-zhi), in China. PLoS ONE 7, e40857. doi:10.1371/journal.pone.0040857.

Welti S, Moreau PA, Decock C, Danel C et al. 2015 - Oxygenated lanostane-type triterpenes profiling in laccate Ganoderma chemotaxonomy. Mycological Progress 14(7), 45.

White TJ, Bruns T, Lee S, Taylor J. 1990 - Amplification and direct sequencing of fungal ribosomal RNA genes for phylogenetics. In: Innis, MA, Gelfand DH, Sninsky JJ. \& White, T.J. (eds) PCR protocols: a guide to methods and applications. San Diego.

Wong L, Bong CFJ, Idris AS. 2012 - Ganoderma species associated with basal stem rot diseaseof oil palm. American Journal of Applied Sciences 9, 879-885.

Wu XL, Dai YC 2005 - Coloured illustrations of' Ganodermataceae' of China. Science Press.

Wu XL, Guo JR, Chen HQ, Liao QZ et al. 1999 - The resources and ecological distribution of the family Ganodermataceae in Jiangfengling, Hainan Island. Acta Ecologica Sinica 19, 159163. (in Chinese).

Xing J, Song J, Decock C, Cui B. 2016 - Morphological characters and phylogenetic analysis reveal a new species within the Ganoderma lucidum complex from South Africa. Phytotaxa 266, 115-124.

Yan YM, Ai J, Zhou LL, Chung AC et al. 2013 - Lingzhiols, unprecedented rotary door-shaped meroterpenoids as potent and selective inhibitors of p-Smad3 from Ganoderma lucidum. Organic Letters 15, 5488-5491.

Yang LZ, Feng B. 2013 - What is the Chinese "Lingzhi"? - A taxonomic mini-review. Mycology. An International Journal on Fungal Biology 4, 1-4.

Yao YJ, Wang XC, Wang B. 2013 - Epitypification of Ganoderma sichuanense J. D. Zhao and X. Q. Zhang (Ganodermataceae). Taxon 62, 1025-1031.

Yu YN, Shen MZ. 2003 - The history of Lingzhi (Ganoderma spp.) cultivation. Mycosystema 22, 3-9 (in Chinese).

Zhao JD. 1988 - Studies on the taxonomy of Ganodermataceae in China. X. Subgen. Ganoderma Sect. Phaeonema. Acta Mycologica Sinica 7, 205-211. 
Zhao JD. 1989 - The Ganodermataceae in China. Bibliotheca Mycologica 132. Berlin: J. Cramer. 176.

Zhao JD, Zhang XQ. 1986 - Taxonomic studies on Ganodermataceae of China V. Acta Mycologica Sinica 5, 219-225.

Zhao JD, Zhang XQ. 1987 - Taxonomic studies on Ganodermataceae of China VIII. Acta Mycologica Sinica 6, 199-210.

Zhao JD, Zhang XQ. 2000 - Flora Fungorum Sinicorum 18: Ganodermataceae. Beijing: Science Press, 204. (in Chinese).

Zhao JD, Hsu LW, Zhang XQ. 1979 - Taxonomic studies on the subfamily Ganodermoideae of China (in Chinese). Acta Mycologica Sinica, 19, 265-279.

Zhao JD, Xu LW, Zhang XQ. 1981 - Ganodermoideae of China. Beijing: Science Press, 1-106 (in Chinese).

Zhao JD, Xu LW, Zhang, XQ. 1983 - Taxonomic studies on the family Ganodermataceae of China II. Acta Mycologica Sinica 2, 159-167.

Zhao JD, Xu LW, Zhang XQ. 1984 - Taxonomic studies on Ganodermataceae of China III. Mycosystema 3, 15-23.

Zhou XW, Li QZ, Yin YZ, Chen YY et al. 2008 - Identification of medicinal Ganoderma species based on PCR with specific primers and PCR-RFLP. Planta Medica 74, 197-200.

Zhou LW, Cao Y, Wu SH, Vlasak J et al. 2015 - Global diversity of the Ganoderma lucidum complex (Ganodermataceae, Polyporales) inferred from morphology and multilocus phylogeny. Photochemistry 114, doi.org/10.1016/j.phytochem.2014.09.023

Zhou XW, Liu Y, Guo MY, Su KQ, Zhang YM. 2016 - Species clarification of the widely cultivated Ganoderma in China based on rDNA and FIP gene sequence analysis. International Journal of Agricultural Biology 18, 932-938. 